\begin{abstract}
UNIVERSIDADE DE SÃO PAULO
INSTITUTO DE PSICOLOGIA

PROGRAMA DE PÓS-GRADUAÇÃO EM PSICOLOGIA ESCOLAR E DO

DESENVOLVIMENTO HUMANO
\end{abstract}

VANESSA LOPES DOS SANTOS PASSARELLI

Em torno da Psicanálise Aplicada

(Versão corrigida)

São Paulo

2012 


\section{Em torno da Psicanálise Aplicada}

(Versão corrigida)

Dissertação apresentada ao Instituto de Psicologia da Universidade de São Paulo como parte dos requisitos para obtenção do título de Mestre em Psicologia.

Área de concentração: Psicologia Escolar e do Desenvolvimento Humano (PSA).

Orientador: Prof. Doutor Paulo Cesar Endo

São Paulo

2012 


\section{AUTORIZO A REPRODUÇÃO E DIVULGAÇÃO TOTAL OU PARCIAL DESTE}

TRABALHO, POR QUALQUER MEIO CONVENCIONAL OU ELETRÔNICO, PARA FINS DE ESTUDO E PESQUISA, DESDE QUE CITADA A FONTE.

Catalogação na publicação

Biblioteca Dante Moreira Leite

Instituto de Psicologia da Universidade de São Paulo

Passarelli, Vanessa Lopes dos Santos.

Em torno da Psicanálise Aplicada / Vanessa Lopes dos Santos Passarelli; orientador Paulo Cesar Endo. -- São Paulo, 2012.

$100 \mathrm{f}$.

Dissertação (Mestrado - Programa de Pós-Graduação em Psicologia. Área de Concentração: Psicologia Escolar e do Desenvolvimento Humano) - Instituto de Psicologia da Universidade de São Paulo.

1. Psicanálise 2. Psicanálise Aplicada (Freud) 3. Transmissão I. Título.

RC504 
PASSARELLI, Vanessa Lopes dos Santos Passarelli. Em torno da Psicanálise Aplicada. Dissertação apresentada ao Instituto de Psicologia da Universidade de São Paulo para obtenção do título de Mestre em Psicologia

Aprovado em:

Banca Examinadora

Prof. Dr. Instituição:

Julgamento: Assinatura:

Prof. Dr. Instituição:

Julgamento: Assinatura:

Prof. Dr. Instituição:

Julgamento: Assinatura: 
À minha avó Antônia, que já não posso mais abraçar, por todo amor que me dedicou e por ter me ensinado tantas coisas que não se aprende nos livros.

À minha mãe, pela paciência, compreensão e companheirismo. E por ter me dado forças quando eu já não acreditava que as tinha.

Ao meu pai, que me transmitiu a curiosidade em aprender e a pensar além do que achamos que vemos. 


\section{AGRADECIMENTOS}

Ao Professor Paulo Cesar Endo, pela orientação cuidadosa e pelos ensinamentos nas aulas, supervisão e grupo de estudos. E, também, por ter inserido em minha formação intelectual uma visão crítica da sociedade, além de ter-me mostrado como a Psicanálise pode colocar-se diante dos fenômenos sociopolíticos.

Aos meus companheiros de grupo de orientação, pela leitura atenta e crítica que fizeram do meu trabalho, pela rica interlocução que me proporcionaram e por estarem sempre por perto.

À Renata Udler Cromberg, que nos últimos quatro anos participou ativamente da minha formação em psicanálise, compartilhando sua escuta clínica e conhecimentos. E, também, aos meus colegas e amigos do grupo de estudos e supervisão, pela oportunidade incessante de troca e construção conjunta.

À Professora Ana Maria Loffredo, por ter-me apresentado a Psicanálise de um jeito tão interessante e, ao mesmo tempo, rigoroso, seja no grupo de estudo, seja nas aulas da graduação. Nutro grande admiração pelo seu empenho em ensinar e formar seus alunos.

Ao Professor Daniel Kupermann, pela sua presença sensível, e por sua recorrente disponibilidade em debater temas que me inquietavam, inclusive as questões que foram mobilizadas a partir deste trabalho. Agradeço pelos anos de supervisão e pelo grupo de estudos que tanto enriqueceu a minha formação.

À Leda Herrmann, e aos amigos do seminário clínico, pelas noites de sexta-feira. Ao CETEC, por ter proporcionado tantos momentos de reflexão sobre a clínica. Ao Ricardo Gomide, por ter apresentado a Teoria dos Campos de um jeito tão singular e compartilhado sua escuta clínica.

Ao professor Yves de La Taille, que me ensinou o ofício de pesquisar e suscitou 
meu interesse em seguir a vida acadêmica.

À Professora Adriana Marcondes, pela imensa e intensa contribuição para o meu olhar como cidadã e para minha formação como profissional engajada com as questões sociais e políticas a partir do estágio na EMEF Conde Matarazzo.

À amiga Débora Ferreira Leite de Moraes, por ter-me ajudado a fazer esse projeto possível, acompanhando de perto minhas inquietações e acolhendo tão docemente as minhas angústias.

Aos amigos André De Martini e Rodrigo Pereira, por terem lido tantas vezes meu trabalho e me ajudado a não esmorecer nesse percurso árduo que é o mestrado.

Aos meus pais e a Daniela, que com ternura e paciência me ajudaram a finalizar este trabalho. Sem vocês nada disso seria possível.

Aos meus amigos e familiares, que compreenderam por tantas vezes a minha ausência e mantiveram-se ao meu lado.

À CAPES e ao Programa de Pós-Graduação em Psicologia Escolar e do Desenvolvimento Humano do Instituto de Psicologia da USP, pela concessão da bolsa de mestrado e pelo apoio financeiro para a realização desta pesquisa. 


\section{RESUMO}

PASSARELLI, V.L.S. Em torno da Psicanálise Aplicada. 2012, 100f. Dissertação (mestrado). Instituto de Psicologia, Universidade de São Paulo, São Paulo, 2012.

Este trabalho trata das discussões que envolvem a Psicanálise Aplicada. Nesse sentido são apresentados a questão do nome e os limites para o analisável, assim como os chamados e lembretes que estão presentes nas falas de psicanalistas na atualidade. Diante dessas questões, recorremos à história da psicanálise. Acompanhamos com Freud as nuances desse fazer psicanalítico, evidenciando o papel central que ocupa em sua teoria, afastando a possibilidade de uma dicotomia entre psicanálise clínica e psicanálise aplicada. Além disso, é possível notar que Freud, dentre outros objetivos, busca com a psicanálise aplicada transmitir a psicanálise na cultura. O psicanalista ora coloca-se como um colonizador de territórios alheios, ora como um estrangeiro que, na fronteira com outra área do conhecimento, produz inflexões em ambas, sem recorrer ao educativo, mas fazendo descobrir. Em seguida, com a ida a Lacan, observam-se as novas formulações do autor e em que medida ele se diferencia da proposição de Freud acerca da psicanálise aplicada, propondo uma visão original. Sua proposta ocorre em meio às mudanças da Psicanálise no cenário francês, contexto que influi diretamente na sua construção teórica e posição institucional. E, por fim, em busca de outros sentidos possíveis para a questão da psicanálise aplicada, apresentamos as considerações de autores da atualidade a propósito do tema. Concluímos, então, que o que parece estar em questão, tendo como sintoma os vários nomes ou os chamados e lembretes, é a transmissão da psicanálise.

Palavras Chave: Psicanálise; Psicanálise Aplicada (Freud); Transmissão 


\section{ABSTRACT}

PASSARELLI, V.L.S. Regarding Applied Psychoanalysis. 2012, 100f. Dissertation (Master Degree). Instituto de Psicologia, Universidade de São Paulo, São Paulo, 2012.

The following study has as its focus the discussions surrounding Applied Psychoanalysis. Towards this end, the issue of name and the limits of the analyzable will be presented, as will the calls and reminders present in the discourse of modernday psychoanalysts. In seeking an understanding of these issues, we turn towards the history of psychoanalysis. Following in Freud the nuances of this psychoanalytical practice and highlighting the central role it plays in his theory, in which the possibility of a dichotomy between clinical and applied psychoanalysis is put aside. Furthermore, one may notice that Freud, amongst other goals, seeks with Applied Psychoanalysis to transmit psychoanalysis throughout culture. The psychoanalyst is positioned now as a colonizer of foreign territories, now as a foreigner who, on the border with another area of knowledge, produces inflections in both, without resorting to the educational, instead promoting discovery. Next, passing on to Lacan, the author's new formulations will be observed, as will the extent to which he differs from Freud's proposal regarding applied psychoanalysis, putting forward his own original view. His proposition occurs in the midst of changes in the French psychoanalytical landscape, context which directly influences his theoretical construction and institutional positioning. Finally, in search of other possible meanings for the question of applied psychoanalysis, we present the considerations of current authors on the subject. Then we conclude that what appears to be concerned with the various symptom or called names and reminders is the transmission of psychoanalysis.

Keywords: Psychoanalysis; Applied Psychoanalysis (Freud); Transmission 


\section{Sumário}

1. INTRODUÇÃO

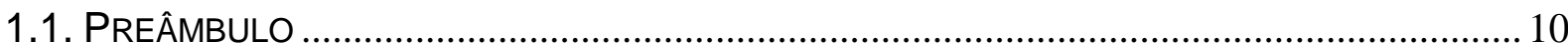

1.2. A QUESTÃO DO NOME E OS LIMITES PARA O ANALISÁVEL................................................. 11

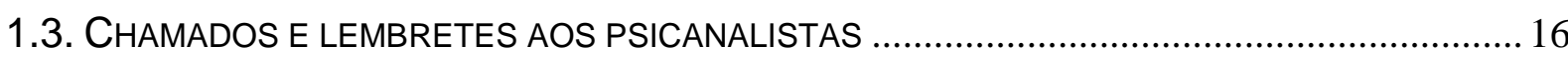

2. VOLTANDO AO COMEÇO ...................................................................................26

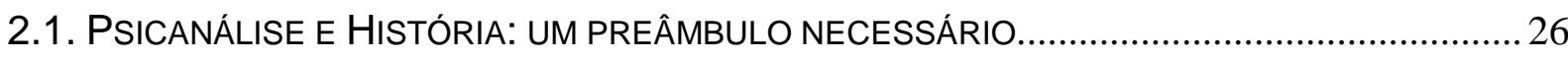

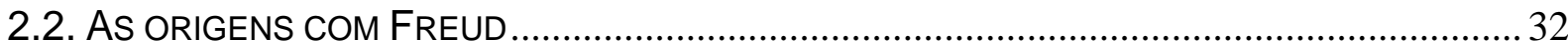

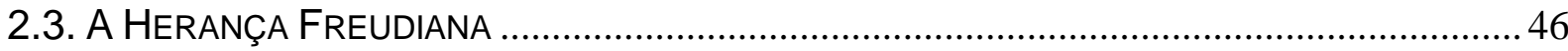

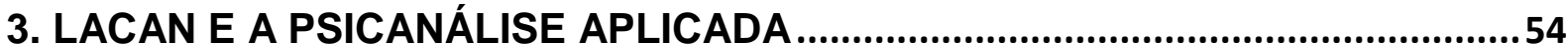

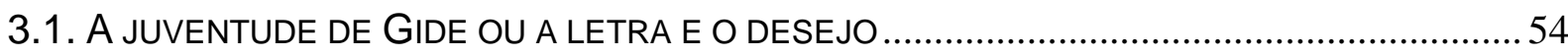

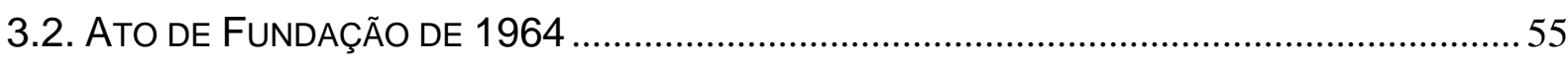

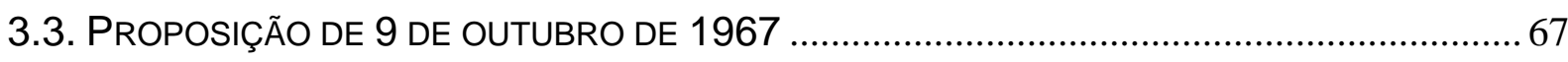

4. EM BUSCA DE SENTIDOS …............................................................................

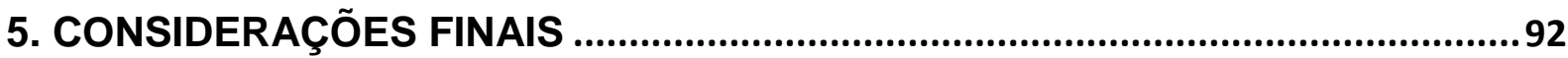

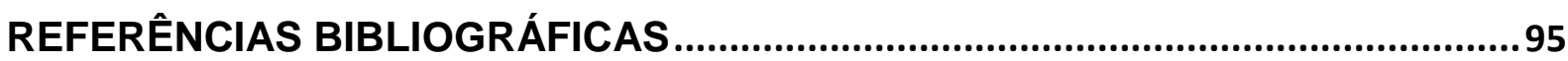




\section{Introdução}

\subsection{Preâmbulo}

Antes de dar início ao trabalho propriamente dito, mostra-se relevante apresentar ao leitor os meandros que levaram a esta pesquisa. O interesse pela psicanálise começou logo no início da Graduação em Psicologia. Desde então, o estudo dessa teoria tornou-se constante, seja na Universidade, seja fora dela, em grupos de estudos, seminários clínicos e eventos diversos. A prática clínica veio apenas no quarto ano, e também nesse ponto, o tripé - análise, estudo da teoria e supervisão - pôde ser construído.

Paralelamente, práticas de estágio foram desenvolvidas em duas instituições. Por um ano, um estágio numa Escola Pública de São Paulo acompanhando uma aluna com necessidades educacionais especiais; posteriormente, um aluno com problemas de aprendizagem. Nesse percurso foi possível refletir e atuar na rede de relações que faziam parte daquela instituição, composta por professores, alunos, coordenação, rede comunitária e equipamentos públicos de saúde e assistência social. Por um semestre, foi desenvolvido também um trabalho com educadores de um abrigo de São Paulo, destinado a crianças e jovens em situação de risco, com o objetivo de oferecer um espaço de escuta e construção de sentidos possíveis para as dificuldades advindas de seus cotidianos de trabalho.

Em ambas as experiências, seja na escola pública, seja no abrigo, em meio às práticas institucionais, questões sociais atravessavam o cotidiano observado: violência, desigualdade social, baixa remuneração dos profissionais e luta pela garantia dos direitos fundamentais de crianças e jovens.

Impactada por esses trabalhos e diante da psicanálise como referência teórica e prática, surgiu, então, o interesse em investigar e refletir sobre os fenômenos sociais que atravessam e produzem efeitos sobre as práticas profissionais. O intuito não foi considerá-los como objetos de estudo hermeticamente apartados das relações e cenários em que emergem, mas sim, justamente, imbricados na vivência das instituições.

Diante dessas questões, o desafio era encontrar um recorte de pesquisa que 
contemplasse tais inquietações. Nessa busca, tendo em vista que se tratava ainda do mestrado, surgiu a ideia de me aprofundar no estudo de alguns dos textos ditos sociais freudianos, para que, num futuro próximo, de posse de um arcabouço teórico consistente, fosse possível eleger um fenômeno social e estudá-lo de maneira aprofundada.

De todo modo, essa tarefa inicial foi se mostrando árdua e ingênua, na medida em que ainda era preciso uma pergunta que norteasse a pesquisa, uma vez que são diversos os caminhos possíveis em face desses hipertextos, tendo em vista sua relação com a metapsicologia, a história do movimento psicanalítico e o tempo histórico vigente.

Já tendo iniciado o mestrado, pude delinear um objetivo inicial: mapear as discussões que envolvem a Psicanálise e outros campos do saber, território mais amplo que, num segundo momento, ofereceria condições para a reflexão sobre os aspectos sociais. Ao realizar esse mapeamento inicial, questões emergiram e ressignificaram o percurso desta pesquisa, norteando-a. Tais questões serão apresentadas a seguir.

\subsection{A questão do nome e os limites para o analisável}

Ao mapear as produções atuais acerca do tema da psicanálise em relação a outros campos do saber, foi possível encontrar muitos artigos, debates e alguns livros que tratam do assunto. Ao ler esses textos, chamaram a atenção as diferentes denominações dadas a esse fazer psicanalítico. Para citar algumas delas: "psicanálise aplicada", psicanálise aplicada (sem aspas), psicanálise em extensão, psicanálise implicada, psicanálise extramuros e clínica extensa. Diante desse cenário, uma questão simples surgiu: por que são tantos os nomes que buscam descrever essa produção psicanalítica? Seriam apenas sinônimos, utilizados vez ou outra, por cada autor? Ou algo mais estaria em jogo nessa Torre de Babel?

Uma pista para a tentativa de responder a tais perguntas é dada por uma dessas nomeações. Trata-se do termo: "psicanálise aplicada", com destaque para as aspas $^{1}$. Por que utilizá-las? Ou, então, por que não abandoná-las e estabelecer 
outro conceito? Ao usar as aspas os autores deixam implícito que o sentido literal dessa expressão - aplicar a psicanálise a outros campos do saber - está sob ressalva e, devido a isso, buscam sinalizar que se afastam dele. Distanciam-se desse uso inadequado do método psicanalítico. De todo modo, vale destacar que não chegam a construir outra denominação.

No entanto, essa não é a regra, outros autores utilizam diferentes conceitos para denominarem o fazer psicanalítico em interface com outras áreas do conhecimento. O que essa "confusão de línguas" pode nos contar? Temos a hipótese de que essa variedade de nomes seria, justamente, uma maneira de se relacionar com esse sentido pejorativo dado à psicanálise aplicada.

É importante destacar ainda, que o termo psicanálise aplicada não é o único a nomear certa maneira de levar a psicanálise a outros campos. Encontra-se, também, a utilização da expressão "psicanálise selvagem". Por esse motivo, mostra-se relevante investigar brevemente o que ela significa.

Freud debruçou-se sobre essa questão, originalmente, em Psicanálise Silvestre (1910). Na ocasião, ele descrevia certa prática clínica que se caracterizava pela aplicação descuidada e sem rigor da teoria psicanalítica aos fenômenos clínicos, levando-nos, de início, a uma dedução simples: a "psicanálise selvagem" não é exclusividade da face psicanalítica que se dirige para a cultura, sociedade e política.

Interessa-nos destacar quais foram os desdobramentos ocasionados pela "Psicanálise Selvagem" naquele contexto. Em certo momento, Freud (1910, p.238) afirma que:

Nem eu nem meus amigos e colaboradores achamos agradável reclamar um
monopólio desse modo no uso de uma técnica médica. Mas, em face dos perigos
para os pacientes e para a causa da psicanálise, inerentes à prática que se pode
antever de uma psicanálise 'silvestre', não tivemos outra escolha. Na primavera de
1910 , fundamos uma International Psycho-Analytical Association (Associação
Internacional de Psicanálise), a que seus membros declararam aderir, pela
publicação de seus nomes, de maneira a serem capazes de repudiar a
responsabilidade por aquilo que é feito pelos que não pertencem a nós e no
entanto chamam a seu procedimento 'psicanálise'.

minha pesquisa, principalmente quando apresentado o termo "psicanálise aplicada". Na fala, na falta das aspas, o termo atinge diretamente meus interlocutores e causa mal-estar. Depois disso repetir-se sucessivas vezes, percebi-me antecipando esse mal-estar e logo passei a contextualizar a pesquisa, a explicar-me. 
E, afinal de contas, destaca Freud (1910, p.238): "os analistas 'silvestres' desta espécie causariam mais dano à causa da psicanálise do que aos pacientes individualmente". Assim, diante dos perigos da psicanálise silvestre, a opção foi colocar a psicanálise entre muros, com a sua institucionalização formal (IPA). Evitavam-se assim danos à causa da psicanálise. É interessante notar esse movimento de expulsão. Ao colocar limites, tem-se a ideia de que o que não é psicanalítico em sua acepção radical será cerceado. Mas, a que causa Freud referese?

Aparentemente, considerando o trecho "o 'psicanalista silvestre' intensificaria as prevenções que os pacientes sentem, devido a suas resistências afetivas naturais, contra os métodos da psicanálise e isso poderia ser evitado" (FREUD, 1910, p.239), a causa defendida parece ser a própria transmissão da psicanálise na sociedade. Assim, a mais alta instância institucional psicanalítica é criada justamente para evitar os riscos, ou, ao menos, garantir que a psicanálise não seja indevidamente responsabilizada por "erros selvagens". E, se formos um pouco mais além, a transmissão da psicanálise e a formação dos psicanalistas, dessa forma, seriam cuidadas de perto.

Destacam-se até aqui dois aspectos: a "psicanálise selvagem" mostra-se como uma questão para a Psicanálise como um todo, seja na prática clínica, seja nas investigações atravessadas por outras áreas do saber. Em decorrência, podemos levantar uma pergunta: analogamente, seria possível supor que a questão nominal em torno do fazer psicanalítico, voltado aos fenômenos culturais, sociais e políticos, revela também a preocupação com os possíveis impactos na transmissão da psicanálise na cultura? É importante lembrar que na época em que Freud escreveu Psicanálise Silvestre (1910) o momento do movimento psicanalítico era outro, ele erguia e queria expandir a Psicanálise. Assim, poderíamos considerar que depois de passados tantos anos a causa citada estaria mantida?

De todo modo, vale notar que o que parece comprometer a psicanálise deveria ficar do lado de fora, como se a questão pudesse ser solucionada dessa maneira. Será mesmo que "o selvagem", a mera aplicação, são aspectos indiferentes à Psicanálise, não pertencem a essa construção teórica de alguma forma?

A tensão e o impasse parecem se instalar não só no que se refere ao nome 
dado a esse fazer psicanalítico em interface com outros campos, e aos receios em relação à mera aplicação da Psicanálise, mas também a um ponto anterior, a saber, a própria validade das incursões freudianas em outras áreas do conhecimento. $E$, nesse sentido, é possível falar da tentativa de impor limites para o analisável. Se antes falávamos de como se faz psicanálise, agora nos deparamos com a delimitação de seu alcance.

No entanto, vale observar com Pontalis, em seu livro Entre o sonho e a dor, que esses limites dar-se-iam em dois registros aparentemente muito distantes um do outro:

o da extensão do método e da interpretação psicanalíticos para além das fronteiras definidas pelo âmbito do tratamento (a chamada psicanálise "aplicada"), o do alcance da técnica psicanalítica conforme as organizações psicopatológicas em questão (problema das "indicações" e "contraindicações") (2005, p.211).

Segundo o autor, embora tenham ocorrido muitas discussões acerca desses dois problemas nos tempos recentes, no seu entender, não se chegou a uma definição clara. $\mathrm{E}$ acrescenta que eles estariam mais próximos do que se poderia supor num primeiro momento. Para Pontalis (2005, p. 211): "ambos concernem ao uso legítimo do instrumento psicanalítico".

Para exemplificar esse argumento, ele afirma que:

Quando nos perguntamos, por exemplo, em que condições um psicanalista pode se autorizar a tratar de fatos sociais e estéticos questão que não concerne apenas aos psicanalistas -, estaremos tão longe quanto imaginamos da preocupação de determinar, de acordo com critérios precisos, que casos estariam ou não sujeitos a um tratamento psicanalítico - questão esta que é exclusivamente da competência dos psicanalistas? (Ibidem, p.211)

Para Pontalis (2005), nos dois casos tratar-se-ia, de fato, de impor limites para o campo psicanalítico, de definir o que, por natureza, não faz parte dele. Enquanto a crítica de uma mera aplicação da teoria a determinado fenômeno, sendo ele clínico stricto sensu ou não, refere-se ao método psicanalítico, a tentativa de colocar limites ao analisável dirige-se ao objeto da psicanálise, nos dois registros levantados anteriormente. 
Seja a possibilidade da psicanálise selvagem, seja a tentativa de colocar limites para o analisável não se mostram como exclusivas à face psicanalítica em interface com outros campos do saber. São questões que se colocam à Psicanálise, e nesse ponto é relevante ir a Freud para compreender e apresentar como ele situava essas práticas psicanalíticas em sua teoria.

É apenas em $A$ questão da análise leiga que Freud nos indica claramente a linha de demarcação entre atividade teórica e prática da psicanálise. Segundo ele:

Não se deve esquecer, contudo, que isso não é o todo da psicanálise, e que quanto ao seu outro aspecto nunca podemos passar sem cooperação de pessoas que tenham tido uma educação preliminar nas ciências mentais. Por motivos práticos temos tido o hábito - e isso é verdade, incidentalmente, também em relação às nossas publicações - de distinguir entre análise médica e aplicada. Mas essa não é uma distinção lógica. A verdadeira linha de divisão situa-se entre a análise científica e suas aplicações igualmente nos setores médico e não médico. (FREUD, 1926/1996, p.247)

Portanto, aquilo que habitualmente se chama de psicanálise aplicada seria uma das modalidades de aplicação da psicanálise científica, sendo a outra a da prática com fins terapêuticos. Vale lembrar que um pouco antes nesse mesmo texto, Freud apontara que:

O emprego da análise para o tratamento das neuroses é somente uma das suas aplicações; o futuro talvez demonstre que não é a mais importante. Seja como for, seria errôneo sacrificar todas as outras aplicações a essa única, só porque diz respeito ao círculo de interesses médicos. (FREUD, 1926/1996, p.238)

O texto mencionado nas duas citações anteriores foi escrito por Freud com o intuito de explicitar que a psicanálise não é uma prática exclusiva dos médicos; ela se estenderia a outros profissionais. Isto desde que se garantisse uma formação adequada. Dessa forma, tanto a aplicação médica (prática com fins terapêuticos) quanto não médica (aplicações da psicanálise a outras áreas do saber) seriam modalidades acessíveis aos médicos e aos leigos.

Vale destacar, no entanto, que Freud considerava importante, muito antes desse escrito, que especialistas de outras áreas pudessem colaborar com essa 
segunda face da psicanálise. Assim, negar aos não médicos o exercício da psicanálise acarretaria, também, reduzir a ampliação da psicanálise para outros campos do conhecimento.

É preciso, ainda, atentar para um importante aspecto. Embora Freud faça essa separação didática entre psicanálise científica e suas aplicações - com fins terapêuticos e em relação a outros campos -, e confira a essa última vertente da psicanálise um papel de importância, não é possível separá-las hermeticamente, recaindo numa dicotomia entre psicanálise terapêutica e psicanálise aplicada. Ambas são atravessadas pela teoria psicanalítica e a constroem, assim como se relacionam entre si. E isso é evidenciado por Freud em vários de seus textos, que serão explorados mais adiante neste trabalho.

É essencial notar também que, diferentemente dos autores que se recusam a designar como psicanálise aplicada o fazer psicanalítico voltado para fenômenos fora da clínica stricto sensu, Freud tratava esse campo claramente como "aplicações da psicanálise a outros campos do saber", sem dotar esse uso de um sentido pejorativo.

Depois desse percurso, pudemos delinear algumas questões importantes, que trouxeram um recorte específico ao tema inicial que, até então, apenas percorria o fazer psicanalítico em relação a outros campos de maneira genérica. A variedade de empregos, os limites para o analisável e também o posicionamento de Freud constroem o desenho inicial da questão desta pesquisa, a saber: o que fica em jogo com esse fazer psicanalítico? O que ele coloca de questões à Psicanálise? Em que medida ele se torna um porta-voz de questões mais amplas? Por que para Freud o emprego do termo psicanálise aplicada não guarda um sentido pejorativo, ao contrário do que ocorre na atualidade? A transmissão da psicanálise ainda é uma causa a ser "defendida" nos dias atuais?

\subsection{Chamados e lembretes aos psicanalistas}

Sugerimos que as discussões que envolvem a questão do nome do fazer psicanalítico voltado a outros campos do saber apontam para impasses e tensões a serem investigados com maior profundidade. É importante apresentar, também, aos leitores, outro importante debate acerca desse tema: os chamados e lembretes 
atuais que parecem funcionar como pontos de alerta para que esse tipo de reflexão não se esgote, e para que a psicanálise não se limite ao reduto da clínica. Destacamos, em especial, a análise voltada aos fenômenos sociais e políticos como um recorte definido, tendo em vista as várias outras interfaces possíveis com a psicanálise.

Como afirma Enriquez (2005, p. 170):

Por muito tempo, o Freud analista da sociedade pouco interessou aos psicanalistas e aos especialistas em ciências sociais, e isso quando não os irritou profundamente, já que eles julgavam sua iniciativa como uma pretensão exorbitante de invadir um campo que não era o seu. No entanto, alguns analistas, sociólogos ou educadores seguiram a via promissora que ele abria. Mas eles eram pouco numerosos e, na maior parte das vezes, ligados desde muito tempo à obra e à personalidade de Freud.

Ele acrescenta ainda que (2005, p.170):

A "obra sociológica" de Freud só foi verdadeiramente lida e compreendida durante a Segunda Guerra Mundial e, sobretudo, nos anos 1960, quando se viu crescer consideravelmente o número de trabalhos tentando adaptar a abordagem psicanalítica à investigação da vida social.

Enriquez (2005, p.170) discorre sobre essa produção, lembrando que: "esses trabalhos, sem lhes fazer injustiça, não veriam a luz do dia sem a obra fundamental de Freud, que colocou a (quase) totalidade das questões ainda hoje apreciadas por aqueles que foram "tomados" pela óptica freudiana". O autor divide-a em três grandes campos: Psicanálise, grupos e organizações, Psicanálise e civilização e Psicanálise e Política.

A interface entre Psicanálise e outros campos do saber reflete-se, ao longo dos anos, não só nesses vários trabalhos, como também em sua inserção na Universidade. Não raro é possível identificar a presença da Psicanálise em diversos cursos de graduação e pós-graduação, estando presente, também, em Colóquios, Seminários, e palestras de cunho interdisciplinar.

Como enfatiza Endo (2008), chama a atenção como autores importantes do 
pensamento social e político contemporâneo, sem recorrerem a qualquer autorização do meio psicanalítico, utilizam em suas obras teses nodais da psicanálise e do pensamento de Freud.

Nesse sentido, Endo (2008, p. 26) traz alguns exemplos:

[...] Norbert Elias, particularmente da segunda tópica, os ensaios críticos de Josef Yerushalmi e Edward Said sobre Moisés, os comentários críticos de Agamben e Girard sobre Totem e Tabu, os diálogos de Zygmunt Bauman com vários textos centrais de Freud, além das leituras de Adorno, Horkheimer e Habermas com textos selecionados da obra freudiana. No que diz respeito ao texto Moisés e o monoteísmo, é, em grande parte, certa fortuna crítica que vem se acumulando em torno desse texto que volta a chamar a atenção dos psicanalistas para esse que foi o último dos grandes escritos de Freud.

É importante reter com Endo (2008), que a considerar esses exemplos e outros, encontram-se muitas produções consistentes que permitem o debate, a crítica e inflexões no campo psicanalítico, no qual a clínica é parte chave. Para Endo (2008, p. 27): "o que se produzirá a partir daí inclui-se numa sucessiva produção de alteridade discursiva, possibilitada pela frequentação e assimilação da psicanálise em outros campos e vice-versa".

No entanto, não se deve esquecer, segundo o autor, que nessa interface, estão presentes os perigos da utilização instrumental dos conceitos e teses psicanalíticas. Quando fora do dispositivo analítico, essas articulações podem ser enfraquecidas e empregadas de maneira superficial e imprecisa. Além disso, pode ocorrer, aponta Endo (2008, p. 27): “a recepção, certamente indevida, de acusações [...] de que os psicanalistas leram mal Freud, tal como não cansa de repetir René Girard (1990), por exemplo, a respeito da leitura dos psicanalistas sobre Totem e Tabu".

A julgar pelo que foi apresentado até aqui sobre a produção intelectual que articula a psicanálise com outros campos do saber, destacando os fenômenos sociais e políticos, poder-se-ia dizer que se trata de um campo fértil e explorado na atualidade, isso sem excluir o debate a respeito desse fazer e as possíveis dificuldades metodológicas que podem se colocar. Como destaca Endo (2008, p.23): "Surgem no Brasil e em outros países iniciativas de pensar, com (grifo do 
autor) e por meio (grifo do autor) da psicanálise, fenômenos sociais e políticos agudos e urgentes. Dentro e fora da psicanálise, com ou sem os psicanalistas".

Em razão disso, seria possível concluir que esses trabalhos não deveriam, então, hoje, produzir estranhamento entre os psicanalistas. Mas produzem, afirma Endo (2008, p.23):

Ainda há colegas defendendo e vociferando a permanência do pensar e do fazer analítico no terreno da clínica stricto sensu, de preferência no intramuros dos consultórios de onde, para alguns, a psicanálise jamais deveria sair. Essa defesa ignora, evidentemente, essa série imensa de trabalhos e desdobramentos técnico-teóricos da psicanálise na intervenção junto à crítica cultural, psicoterapias grupais, análises institucionais, proposição de políticas públicas e a clínica psicanalítica do social.

Alguns dirão, acrescenta Endo (2008, p.23): "[...] que o que o psicanalista fala, escreve e faz fora da clínica dos consultórios nada tem a ver com a psicanálise, mas sim com a participação social do psicanalista como cidadão". No entanto, o autor enfatiza que não se pode desconsiderar essa crítica. Para ele, ela é apenas ingênua e hesitante, reivindica que a psicanálise é legítima somente no seu setting originário.

Nesse sentido, por fim, vale considerar o que enfatiza Endo (2008, p. 24):

[...] não se deve temer uma psicanálise sem clínica, criando a falsa oposição clínica versus social, já que o pensamento psicanalítico é sempre tributário da prática clínica, mesmo quando ele ignora seus princípios, e é aí que os psicanalistas são fundamentais, não como homologadores ou especialistas, mas como debatedores competentes e interessados na ultrapassagem dos impasses deixados por Freud e os que o sucederam. [...] De outro modo, tantos são os atravessamentos de cá para lá e vice-versa, entre a psicanálise e outros saberes, que já não é sequer relevante incentivá-los ou coibi-los, mas sim examiná-los mais e melhor, protegendo e cultivando as excelentes indagações que germinam nos debates entre estrangeiros.

A partir das considerações feitas até aqui podemos notar que, se em seu início, as produções freudianas voltadas para outros campos não produziam necessariamente o interesse ou dispersão almejados, na atualidade é possível dizer que sua disseminação é extensa e inquestionável. Vale destacar ainda um ponto importante de diferenciação: enquanto na primeira parte desta introdução falávamos 
da centralização da Psicanálise com a criação da IPA em 1910, hoje a Psicanálise está pulverizada em muitas instituições de formação, está presente nas Universidades, em inúmeros outros campos do conhecimento e, também, na cultura.

Na mesma direção apontada por Endo (2008), Koltai (2000, p.29) afirma que:

Bem sei que a articulação entre o pensamento social e político com o analítico não caminha sem tropeços; mas me parece fundamental ultrapassar uma certa visão ingênua que reduziria a psicanálise ao estudo do desenvolvimento normal e patológico do indivíduo, deixando às outras ciências humanas o estado de tudo aquilo que diria respeito ao coletivo. O que, todavia, não significa que o analista deva introduzir o social e o político no espaço analítico.

A questão seria de fundo, segundo a autora. Ela, então, interroga se 0 analista poderia ausentar-se, não se implicar no que acontece na sociedade. Limitando-se assim ao reduto da clínica. A esse respeito, em seguida, Koltai (2000, p.29) posiciona-se:

Não vejo como, pois [o analista] acabará fatalmente sendo interpelado pelos acontecimentos, quer queira, quer não. Refletir sobre a violência, a guerra, a discriminação, parece-me obrigatório, já que são sinais de um mal-estar na civilização, cujos efeitos 0 analista acolhe em seu consultório sob a forma de sintoma. [...] o sintoma é outro nome para o mal-estar na civilização. Nenhuma civilização pode realizar o fantasma da felicidade. Qualquer civilização terá que tratar, ou pelo menos gerenciar, as aporias da condição humana.

Por essa razão, para a autora, mostra-se importante o analista interrogar-se sobre de que maneira seu analisando é impactado pelo social e político que o cerca. Efeito que está presente em seus significantes. Além disso, é relevante que o psicanalista considere o quê dos conteúdos do fantasma encontram guarida na realidade atual. Segundo Koltai (2000, p.30): "Social e político marcam a escuta do analista".

Betty Fuks (2003, p. 8) retorna à Freud e faz apontamentos nesse mesmo sentido: 
[...] Freud afirmou a prática psicanalítica como a especificidade de sua invenção, ao mesmo tempo em que, levando as consequências da descoberta até o fim, estendia seu entendimento aos sintomas e ao mal-estar da coletividade humana. Assim, rapidamente ele começou a construir um complexo instrumental teórico sobre cultura, totalmente articulado com as bases do saber psicanalítico, para o qual o fato de a "outra cena" se apresentar como individual ou coletiva não tinha qualquer importância.

Ela indica ainda, acerca do período pós-freudiano, que embora esse princípio tenha sido relegado por muitas vezes, reduzindo a psicanálise a uma psicologia do indivíduo, no intento da adaptação do eu à sociedade. Cabe ao psicanalista ser crítica da cultura na qual se insere.

Major (2000, p.1), por sua vez, em entrevista, ao ser indagado acerca do papel da psicanálise e do psicanalista no mundo contemporâneo, afirma que:

O psicanalista deve estar presente na reflexão mais aguda dos problemas da sociedade contemporânea - quando se trata do direito à vida, à liberdade de expressão ou à dignidade do indivíduo. Ele se preocupa com isso na prática cotidiana. Deve, pois, interessar-se pelas transformações necessárias do direito, nacional e internacional, pelas questões do poder, de soberania e de crueldade que os conflitos envolvem, pelas guerras, pelas destruições, participar de tudo o que atua em favor da democracia digna desse nome.

Nesse trecho, Major vai além, convocando os psicanalistas a implicarem-se produzindo reflexões a respeito do contemporâneo no que se refere aos fenômenos sociopolíticos. Vale lembrar que essa entrevista foi realizada por ocasião do Segundo Encontro dos Estados Gerais da Psicanálise ${ }^{2}$. Nesse contexto, quando indagado sobre o porquê da criação desse movimento psicanalítico, Major afirmou (lbidem, p.1):

O principal motivo veio do esquecimento, do recalcamento e mesmo da ignorância intrínseca da política no movimento psicanalítico. A história da psicanálise no Brasil teve um papel desencadeador dessa tomada de consciência. Na realidade, foi no lançamento do livro de Helena Besserman Vianna, "Não Conte a Ninguém" (ed. Imago), em 1997, em Paris, e do qual fiz o prefácio. No lançamento, foi decidida a convocação dos Estados Gerais. Tivemos que tomar conhecimento dos sintomas que podem produzir na realidade a implicação desconhecida da dimensão política na transmissão da experiência analítica e nas instituições psicanalíticas. Os sintomas que se 
manifestaram no Rio não eram apenas locais ou regionais, mas internacionais, pois diziam respeito a todo o movimento desde a Segunda Guerra. Essas graves vicissitudes da história são muito mais alarmantes quando se leva em conta que Freud não se contentou em descobrir as leis do funcionamento psíquico inconsciente. Ele soube articular o inconsciente como uma produção do social e do político. Existe uma resistência enorme em reconhecer que ele é um grande pensador da política, como testemunham vários de seus trabalhos, desde a "Psicologia de Massa" até "Moisés e o Monoteísmo".

Não serão tratadas em detalhes, neste trabalho, as vicissitudes e as tramas da psicanálise e suas instituições, evidenciadas por Helena Besserman Viana nos anos 90. Interessa, neste momento, reconhecer o silêncio da psicanálise, assim como o vislumbre concreto e necessário do rompimento dele, apontado pelo autor.

No entanto, na primeira citação de Major, ele confere uma dimensão de "dever" à incursão da psicanálise em direção aos fenômenos sociopolíticos. Ora, quando Major (2000) afirma que o psicanalista: "deve (grifo meu) estar presente na reflexão mais aguda dos problemas da sociedade contemporânea [...] Deve (grifo meu), pois, interessar-se pelas transformações necessárias [...]”, ele parece apontar aos psicanalistas uma ética prescritiva. Como se ele inscrevesse na ética psicanalítica algo que até então era estranho a ela, embora sempre presente como direção a ser tomada.

O que poderia indicar esse "chamado"? O que, eventualmente, ele buscaria ao convocar os psicanalistas?

Ainda em torno desse debate, que envolve a psicanálise e seu tempo histórico, Sérgio Paulo Rouanet ${ }^{3}$ (2004) mostra-se como um porta-voz estrangeiro. Em entrevista concedida à Revista Percurso no. 33, ele sugere que, apesar da ampla produção teórica da psicanálise contemporânea, seriam poucos os trabalhos psicanalíticos voltados à compreensão dos fenômenos sociopolíticos e do mal-estar na cultura de nossos tempos. Ele aponta que existiria certa relutância por parte dos psicanalistas da atualidade em sair dos consultórios e tentar enfrentar problemas do tempo em que vivem. Rouanet destaca que existiriam exceções, mas poder-se-ia dizer que a preocupação de Freud com a sociedade não é permanece.

\footnotetext{
3 Figura de destaque no meio cultural e no cenário político brasileiro, Sérgio Paulo Rouanet, diplomata,
} ensaísta, conferencista e professor, é o primeiro pensador não psicanalista a ser entrevistado pela Percurso. 
O autor ilustra indicando o Mal-Estar na Civilização, O Futuro de Uma Ilusão e mesmo Moisés e o Monoteísmo. Para Rouanet (2004), Freud sabia que para fazer uma psicanálise da alma precisaria fazer uma psicanálise da história e da sociedade. Ele ainda revela ter a impressão de que essa posição de Freud não é seguida nos tempos de hoje.

Mais adiante, Rouanet (2004), ao ser informado dos inúmeros trabalhos realizados no sentido que ele aponta ser necessário, afirma que sua preocupação nunca foi simplesmente criticar e sim chamar a atenção para a necessidade e importância de uma reflexão teórica sobre os problemas políticos (nos âmbitos micro e macro), uma reflexão que se utilize da psicanálise.

Para Mario Fuks (2005), as afirmações de Sérgio Paulo Rouanet são surpreendentes no que se refere ao movimento psicanalítico na América Latina. Segundo ele:

Surpreende, sobretudo, por ser Rouanet não somente um conhecedor destacado da psicanálise, mas também um intelectual latino-americano. Se, por um lado, a afirmação reforça o chamado realizado por René Major na convocatória à constituição dos Estados Gerais da Psicanálise no final dos anos $90^{4}$, de outro chama a atenção por não mencionar a quantidade de trabalhos sobre esses temas que foram apresentados tanto no encontro de 2003, no Rio de Janeiro, como no de Paris, em 2000, e nos três encontros latinoamericanos realizados sucessivamente em São Paulo e Buenos Aires (2005, p.3).

Mario Fuks (Ibidem, p.3) destaca também que:

A partir dos anos 70, muitos analistas da América Latina questionaram a profissionalização acrítica presente em suas instituições e sua omissão em questões sociais e políticas, conduzindo a rupturas e reposicionamentos. Esse movimento ganhou visibilidade na Argentina e no Uruguai e, num segundo momento, no Brasil. Foi a partir desse momento que os escritos de Freud sobre sociedade e cultura começaram a sair verdadeiramente de seu reduto nas estantes, e ganharam potência nova como instrumentos de análise da realidade social e política em suas dimensões individuais e coletivas.

Ele destaca, nessa perspectiva, os trabalhos de J. Bleger, M. Langer, L.

4 Para mais informações, consultar o site: http://www.estadosgerais.org/ 
Rozitchner e de outros analistas dos grupos Plataforma ${ }^{5}$ e Documento ${ }^{6}$. Também foram realizados trabalhos sobre ideologia na linha lacaniano-althusseriana.

Mário Fuks (2005, p.4) ainda acrescenta que:

No longo período de governos militares, os analistas tiveram a experiência da violência ditatorial e do terrorismo de estado, a cultura do medo e o exílio externo e interno e, quando puderam, escreveram sobre isso. Exploraram em todas suas dimensões as relações dos sujeitos com o poder, a alienação, o desamparo e a crueldade presente nessas situações sociais de alto impacto traumático, mas aplicáveis também a outros contextos. M. Viñar, J. Freire Costa, Gilou García Reinoso e Hélio Pellegrino, entre outros, demonstraram como a perda de vínculos, a deterioração e a quebra do sistema de ideais, bem como o fim de projetos coletivos, impõem uma subjetividade fragilizada, quadros de verdadeira "demolição" da identidade e uma cultura de violência e medo, entre outros efeitos.

Essa linha de trabalhos apresenta para Mario Fuks (2005) uma evidente continuidade do espírito da intervenção e combate no campo político, cultural e social que caracterizou o trabalho freudiano. Haveria neles um empenho forte e determinado em incluir a dimensão clínica, construir elementos conceituais que resignifiquem e ampliem, ao mesmo tempo, a totalidade do campo psicanalítico.

Tendo em vista as colocações dos autores até aqui, é possível notar certa ambiguidade em relação à articulação entre Psicanálise e os fenômenos sociopolíticos. Com Enriquez (2005), Endo (2008) e Mário Fuks (2005), fica evidenciado o volume incontestável de produções nesse sentido; no entanto, mesmo assim, seja com o "chamado" de Major (2000), seja com o "lembrete" de Rouanet (2004), e as considerações de Koltai (2000), Betty Fuks (2003) e do próprio Endo (2008), pontua-se que, em certo sentido, em vários momentos esse fazer psicanalítico é abandonado, relegado e, a meu ver, parece ser retomado, em seguida, num sentido afirmativo e necessário. É como se dissessem: algo não vai

\footnotetext{
5 Segundo Mezan (2002), no congresso de Roma de 1969, um grupo de analistas "latinos" - franceses, italianos, argentinos - questionava vivamente a estrutura de poder e o tipo de formação vigentes na IPA. Denominaram-se Plataforma Internacional, e sua ala argentina iria estar na origem direta de importantes transformações na psicanálise latino-americana.

6 Para mais informações, consultar o artigo: "Psicanálise e marxismo: a fratura da Associação Psicanalítica Argentina" (1971), escrito por Hugo Vezetti e traduzido para o português por Fernando Antonio Pinheiro Filho.
} 
bem. Para eles essa seria uma herança deixada por Freud.

O que esse lembrar recorrente da importância e relevância desse fazer tem a nos dizer?

Como se pode notar, trata-se de um tema complexo, que de imediato coloca várias questões, seja pela ambiguidade e contradições em relação a esse fazer, seja pelos lembretes/chamados feitos para que ele não seja esquecido ou relegado. É possível afirmar que um conflito fica em jogo, movimentos contrários expressam-se em relação a essa face da psicanálise. Como apontado anteriormente, algo não vai bem. 


\section{Voltando ao começo}

Neste capítulo, o objetivo será recolher nos meandros da história da psicanálise como se delineou o fazer psicanalítico em direção a outros campos, buscando destacar o que fica em jogo nessa face da psicanálise a partir das palavras de Freud. Com isso, podemos reunir elementos que ajudem a responder às questões apresentadas na Introdução deste trabalho.

\subsection{Psicanálise e História: um preâmbulo necessário}

Diante da tarefa de retomar a história da Psicanálise no que se refere ao fazer psicanalítico em relação a outras áreas do saber, colocou-se como tarefa inicial delinear de que maneira seria tratado esse material. Para tanto, duas leituras foram fundamentais: A Escrita da História (1975/2011) e História e Psicanálise: entre ciência e ficção (1987/2011), de Michel de Certeau. Cabe ressaltar que é como analista que o trato e não como historiadora da psicanálise. Interessam menos os fatos dispostos em uma ordem cronológica, sem restos, incoerências ou contradições, e mais o que esse trânsito pela história aporta como questões e significados. Vejamos em que medida Michel de Certeau sustenta e ilumina certo fazer diante da história, e como nos serviremos dele neste trabalho.

Como aponta De Certeau (1975/2011), a história moderna ocidental tem início ao diferenciar presente e o passado. Dessa forma, distingue-se da tradição religiosa da qual, entretanto, não conseguirá jamais separar-se totalmente, mantendo com esta arqueologia uma relação de dívida e de rejeição. E, por fim, a terceira forma deste corte, que organiza também o conteúdo nas relações de trabalho com a natureza, supõe em toda parte uma clivagem entre o discurso e o corpo (social). Ela faz falar o corpo que se cala.

Segundo o autor, a violência do corpo alcança a página escrita sem estar de fato presente, revela-se pela articulação dos registros que historiador recolheu diante da presença que os produziu. E, apenas de longe, é percebida, desafiando o saber 
produzido em sua ausência.

Para De Certeau (1975/2011, p. XVI):

\begin{abstract}
Uma estrutura própria da cultura ocidental está, evidentemente, indicada nesta historiografia: a inteligibilidade se instaura numa relação com o outro; se desloca (ou "progride") modificando aquilo de que faz seu "outro" - o selvagem, o passado, o povo, o louco, o Terceiro Mundo. Através dessas variantes, heterônomas entre si etnologia, história, psiquiatria, pedagogia, etc. - se desdobra uma problemática articulando um saber-dizer a respeito daquilo que o outro cala, e garantindo o trabalho interpretativo de uma ciência ("humana"), através da fronteira que o distingue de uma região que espera para ser conhecida.
\end{abstract}

Sendo assim, trata-se de construir um saber sobre o outro que no momento mesmo em que é produzido distorce o que de fato se apresenta. Chega-se assim a um conhecimento enviesado por um lugar que se ocupa, desconsiderando a articulação com o objeto de análise.

Mais adiante, De Certeau (1975/2011) aponta que, inicialmente, a historiografia faz a separação entre o presente e passado, repetindo sempre o gesto de dividir. A cronologia é composta, assim, de "períodos" (por exemplo, Idade Média, História Moderna, História Contemporânea). Cada um deles marca uma diferença entre o que vigorava e o que passa a existir no momento do corte. Para o autor (1975/2011, p. XVII): "o corte é o postulado da interpretação (que se constrói a partir de um presente) e seu objeto (as divisões que organizam as representações a serem reinterpretadas). O trabalho determinado por esse corte é voluntarista".

Vale atentar, segundo o autor, para o fato de que, a escrita da história está a serviço de uma inteligibilidade presente, sendo assim é feita uma triagem entre os registros do passado para alcançá-la. Porém, afirma De Certeau (1975/2011, p. XVII):

[...] aquilo que esta nova compreensão do passado considera como não pertinente - dejeto criado pela seleção dos materiais, que permanece negligenciado por uma explicação - retorna, apesar de tudo, nas franjas do discurso ou nas suas falhas: "resistências", "sobrevivências" ou atrasos perturbam, discretamente, a perfeita ordenação de um "progresso" ou de um sistema de interpretação. São lapsos na sintaxe, construídos pela lei de um lugar. Representam aí o retorno de um recalcado, quer dizer, daquilo que num dado momento se tornou impensável para que uma identidade nova se tornasse pensável. 
Desse modo, mesmo que a escrita seja resultado do sentido do presente, e que assim seja criada uma nova identidade, não há como evitar as falhas e contradições desse discurso, que revelam uma história vivida. Nesse sentido, fica claro que o exercício da escrita da história depara-se com uma tradição em que o novo é resultado de um lugar que se ocupa, e que orienta o saber a partir de um corte arbitrário. Por vezes, desconsiderando a articulação entre os fenômenos apartados pela ruptura no tempo. É importante reter a esse respeito, que o trabalho o trabalho a ser empreendido, neste capítulo, pelos meandros da História da Psicanálise, pretende distanciar-se dessa forma de "fazer história".

Mais ao final do livro, De Certeau (1975/2011) discorre acerca do que Freud fez da história. Essas considerações interessam na medida em que fornecem perspectivas importantes para o trabalho diante do material histórico, tendo como referência a própria produção freudiana. Para o autor (1975/2011, p.307): "o que chamamos inicialmente história não é senão um relato [...] É o imaginário de que temos necessidade para que o alhures repita apenas o aqui".

Segundo De Certeau (1975/2011, p. 307):

Nos pedaços que o imaginário de sua sociedade organiza antecipadamente, operam-se deslocamentos, acrescentam-se outras peças, estabelecem-se distâncias e comparações entre elas, discernindose nesses indícios o vestígio de outra coisa, remetendo assim a uma construção desaparecida. Em suma, criam-se ausências, diz o autor. Com esses documentos - através de artimanhas que não necessitam ser lembradas aqui - constitui-se um passado capturado, mas não reabsorvido no seu novo discurso. Portanto, seu trabalho é também um evento. Porque não repete, tem como efeito transformar a história-lenda em história-trabalho. Um mesmo processo operatório transforma a relação do historiador com o objeto passado do qual se falava, e a relação interna entre os documentos que designavam tal objeto.

Este último sentido é que vai constituir, aqui, a questão da história, afirma De Certeau (1975/2011), que em seguida aponta: "Não para deduzir de um saber tirado de Freud sua "concepção" da história [...] mas para revelar aquilo a que correspondem e chegam as incursões de Freud na região "histórica" da sua cultura".

O autor, então, traz algumas questões: como Freud trata essa parte de sua linguagem, na qual sua curiosidade correspondeu ao gosto de tantos dos seus contemporâneos? Como analista, o que faz ele da história? De Certeau (1975/2011) recorrerá ao exame do trabalho de Freud em um caso particular, a partir de uma de 
suas obras: Uma neurose demoníaca no século XVII (1922). Fazendo isso, segundo ele, corre-se o risco de abrir algumas questões, sem ter como lhes dar um verdadeiro estatuto científico, sem ter contudo a pretensão ilusória de resolvê-las.

Talvez, revela De Certeau (1975/2011, p.308):

\begin{abstract}
essa observação seja, ela também, uma reação contra uma maneira de se servir da psicanálise. Diversos trabalhos, tanto em etnologia quanto em história, mostram que o uso dos conceitos psicanalíticos ameaça tornar-se uma nova retórica. Eles se transformam, então, em figuras de estilo. Os recursos à morte do pai, ao Édipo ou à transferência, servem para tudo. Sendo esses "conceitos" freudianos supostamente utilizáveis para todos os fins, não é difícil calcá-los sobre as regiões obscuras da história. Infelizmente, não são mais do que utensílios decorativos quando têm por objetivo apenas o de designar ou cobrir pudicamente 0 que o historiador não compreende. Circunscrevem o inexplicado, não o explicam. Confessam uma ignorância. Instalam-se onde uma explicação econômica ou sociológica deixa um resto. Literatura de elipse, arte de apresentar dejetos ou sensação de uma questão, sim; mas análise freudiana, não.
\end{abstract}

Sendo assim, mesmo tendo a psicanálise como referência na análise da história é preciso atentar para determinado uso de seus conceitos, que meramente explicam ou estabelecem um sentido de antemão, sem considerar propriamente o texto e seus meandros. O que anteriormente neste trabalho, denominamos como a aplicação de conceitos a determinado fenômeno.

De Certeau (1975/2011, p.312) destaca, acerca da análise empreendida por Freud a respeito do texto citado, que:

À primeira vista seu autor tem diante do manuscrito uma atitude bem característica: revolve uma terra para ele ainda virgem e psicanaliticamente não "cultivada" - a saber, esses escritos provenientes do século XVII - o que ocorre não porque ela the pareça estranha, supostamente distante, e, no seu conjunto, como um passado, mas, pelo contrário, porque é sua. Os documentos que lê pertencem à sua paisagem. Fazem parte do seu presente, que é um presente não analisado. Indício revelador. [...] o manuscrito não Ihe propõe outro problema além dos que lhe propõe qualquer outro fragmento da sua linguagem.

Por fim, interessa-nos destacar com De Certeau (1975/2011, p.308) que:

A esse território de palavras, colocadas como resto na geografia cultural de hoje (o passado não é inicialmente senão uma modalidade do presente), a análise vai dar como que uma espessura. Dessa maneira procede, aliás, a terapêutica freudiana: 
decifra nas palavras do doente uma organização que "denuncia" uma gênese; ela as remete, assim a eventos que ocultam e que se tornam - enquanto ausentes e presentes - um passado. A análise de Freud faz de relações entre palavras vestígios de relações entre tempos. Através de um trabalho sobre o texto, ela transforma a superfície dos elementos verbais numa rede de inter-relações que organizam esta superfície, que articulam as palavras em função de coisas apagadas ou perdidas e que fazem do texto o signo enganador de eventos passados.

Vale lembrar que ao nos debruçarmos sobre a história da psicanálise no que se refere aos meandros da Psicanálise Aplicada, estamos diante da interface entre Psicanálise e História, e sendo assim mostra-se importante "fazer descobrir" e, justamente, oferecer uma análise que se distancie do trabalho do historiador e aproxime-se do trabalho de um psicanalista, tal como levantamos no início desta seção.

Em seu livro seguinte: História e Psicanálise: entre ciência e ficção, De Certeau (1987/2011) dedica-se com mais profundidade às questões que cercam a interface entre Psicanálise e História, assim como se detém no fazer historiográfico.

Interessa-nos destacar o ponto em que De Certeau (1987/2011, p. 71) discorre detidamente sobre a relação entre Psicanálise e História:

A psicanálise articula-se a partir de um processo que é o núcleo da descoberta freudiana: o retorno do recalcado. Esse "mecanismo" utiliza uma concepção do tempo e da memória; nesse caso, a consciência é, simultaneamente, a máscara ilusória e o vestígio efetivo de acontecimentos que organizam o presente. Se o passado (ao ter lugar e forma em um momento decisivo no decorrer de uma crise) é recalcado, ele retorna, mas sub-repticiamente, ao presente do qual havia sido excluído.

Sendo assim, não se evidencia um corte entre passado e presente, eles entrecruzam-se. De Certeau (1987/2011) fala, em seguida, de duas estratégias de tempo: a da psicanálise e da história, destacando em que medida ela se diferenciam.

Acerca da psicanálise, o autor começa afirmando que haveria uma familiaridade em relação a esse passado que o presente acreditou ter excluído para tomar o seu lugar. Para De Certeau (1987/2011, p.71): 
O morto assombra o vivo; ele re-morde. Assim, a história "canibal" e a memória se tornariam o recinto fechado em que se opõem duas operações contrárias: por um lado, o esquecimento, que não é uma passividade nem uma perda, mas uma ação contra o passado; e, por outro, o vestígio mnésico, que é o retorno do esquecido, ou seja, uma ação desse passado, daqui em diante forçado ao disfarce.

O que configura um conflito entre duas forças contrárias. De Certeau (1987/2011, p.72) acrescenta que:

De maneira mais geral, qualquer ordem autônoma constitui-se graças ao que ela elimina, produzindo um "resto" condenado ao esquecimento; no entanto, o excluído insinua-se, de novo, neste lugar "limpo" ["propre"], instala-se aí, suscita a inquietação, torna ilusória a consciência segundo a qual o presente julga estar em "sua casa", fixa aí seu esconderijo; e esse "selvagem", esse "ob-sceno", esse "lixo", essa "resistência" da "superstição" vai inscrever aí - à revelia do proprietário (o ego) ou contra ele - a lei do outro.

Sendo assim é como se ele dissesse que não somos os senhores de nossa própria casa. Para o autor, a historiografia, por sua vez, desenvolve-se, pelo contrário, em função de um corte entre o passado e o presente, como já apontado anteriormente, porém aqui ele aprofunda o tema. Segundo De Certeau (1987/2011, p. 72):

Ela é o resultado das relações de saber e de poder entre dois lugares supostamente distintos: por um lado, o lugar presente: científico, profissional, social do trabalho, o aparato técnico e conceitual da pesquisa e da interpretação, a operação de descrever e/ou de explicar; e, por outro, os lugares (museus, arquivos, bibliotecas) em que são guardados, inertes, os materiais que são objetos da pesquisa e - em um segundo momento, deslocados no tempo - os sistemas ou acontecimentos do passado, cuja análise é permitida por intermédio desses materiais. Uma fronteira separa a instituição atual (que fabrica representações) das regiões antigas ou longínquas (encenadas pelas representações historiográficas).

$\mathrm{E}$, nesse sentido, evidencia-se claramente a diferença em relação à psicanálise que não considera essa separação arbitrária possível. Para De Certeau (1987/2011, p. 72):

Mesmo que a análise historiográfica postule uma continuidade 
(genealogia), uma solidariedade (filiação) ou uma conivência (simpatia) entre seus operadores e seus objetos, ela estabelece uma diferença entre uns e outros, marcada, aliás, desde o princípio, por uma vontade de objetividade. O espaço organizado por ela é, ao mesmo tempo, dividido e hierarquizado, comportando um "próprio" (o presente de uma prática) e um "outro" (um "passado" estudado). Tal fronteira atravessa, por um lado, a prática em que o aparato de pesquisa distingue-se do material tratado e, por outro, a encenação escriturária em que o discurso do saber interpretativo domina 0 passado representado, citado e conhecido.

Como revela o autor, a psicanálise e a historiografia têm, assim, duas maneiras distintas de articular o passado e o presente em suas produções. Para De Certeau (1987/2011):

[...] no entanto, não deixam de se desenvolver no terreno de questões análogas: procurar princípios e critérios em nome dos quais seja possível compreender as diferenças ou garantir as continuidades entre a organização do atual $e$ as antigas configurações; conferir valor explicativo ao passado e/ou tornar o presente capaz de explicá-lo; reconduzir as representações de outrora ou atuais às suas condições de produção; elaborar (de onde? De que modo?) as maneiras de pensar e, portanto, de superar a violência (os conflitos e os acasos da história), incluindo a violência que se articula no próprio pensamento; e definir e construir a narrativa que é, nas duas disciplinas, a forma privilegiada conferida ao discurso da elucidação. Os cruzamentos e debates dessas duas estratégias, desde Freud, sublinham as possibilidades e os limites da renovação que o encontro entre elas oferece à historiografia.

Tendo em vista o que foi apresentado aqui é possível identificar quais são os meandros que envolvem a escrita e análise de um material histórico. Pudemos investigar quais são as diferenças entre o fazer historiográfico e como a psicanálise se distancia disso, propondo outra forma de articular o presente e o passado a partir das suas teses centrais.

\subsection{As origens com Freud}

Buscar-se-á neste item colher nas tramas da história pontos e nuances que nos ajudem a investigar o que fica em jogo com o fazer psicanalítico em interface com outros campos do saber. Para tanto foram feitas leituras das Atas da Sociedade Psicanalítica de Viena, das Cartas de Freud a Ferenczi, das Cartas de Freud a Jung e das biografias de Peter Gay e Ernst Jones, além outros textos. 
Freud manifestou bem cedo seu interesse pelo diálogo entre a psicanálise e as ciências do espírito (mais conhecidas hoje como ciências humanas e sociais). Segundo Roudinesco e Plon (1998), inicialmente, foi a Sociedade Psicológica das Quartas-feiras $^{7}$ que serviu de contexto para as exposições e discussões, amiúde apaixonadas, que versavam sobre a aplicação da psicanálise aos campos literário, artístico, mitológico e histórico.

Como revela De Certeau (1987/2011), estes três domínios ("a mitologia, a história da literatura e a das religiões") já ocuparam as reuniões das quartas-feiras à noite na casa de Freud (a partir de 1902) e, em seguida, da Sociedade Psicanalítica de Viena (fundada em 1908). No início, Rank (secretário do grupo), Adler, Federn, Sachs, Schilder, Steiner e ainda outros - assim como, mais tarde, Reik, Tausk e Lou Andreas-Salomé - abordavam Wagner, Nietzsche, o incesto, o símbolo e os mitos, entre outros temas. Em breve, essas "aplicações" da psicanálise seriam objeto de discussões mais amplas ou de correspondências com Abraham (Berlim), Ferenczi (Budapeste), Groddeck (Baden-Baden), Jung (Zurique), Jones (Londres), Putnam (Boston), etc.

Como revelam Nunberg \& Federn (1974), logo na introdução das $\operatorname{Atas}^{8}$ da Sociedade Psicanalítica de Viena, os psicanalistas que faziam parte das reuniões das quartas-feiras viam a psicanálise como muito mais que uma psicopatologia e um método para tratar os enfermos. Sabiam que o homem era um ser tanto social como uma entidade biológica, e reconheciam que as relações do indivíduo com seu ambiente se expressam tanto em sua conduta como nas obras artísticas e literárias, na religião e nas instituições sociais. Dessa forma, pensavam que era necessário ocupar-se não somente do ser humano doente, mas também da literatura, religião, filosofia, antropologia, sociologia, etc. $\mathrm{Na}$ verdade, realizaram-se, nos vários encontros, muitos debates sobre a interação dos fatores biológicos, sociais e históricos no desenvolvimento do indivíduo e da humanidade.

Nesses primeiros anos, apontam Nunberg \& Federn (1974), era difícil obter material clínico adequado para um estudo psicanalítico, mas esse material podia ser

\footnotetext{
$7 \quad$ Segundo Freud (1914/1996), a Sociedade Psicológica das quartas-feiras foi criada em 1902. Tratava-se do primeiro grupo reunido em torno dele com a intenção expressa de: "aprender, praticar e difundir o conhecimento da psicanálise" (p.35).

$8 \quad$ As Atas da Sociedade Psicanalítica de Viena utilizadas nesse trabalho percorrem os anos de 1906 a 1908; trata-se do primeiro volume dessa publicação.
} 
obtido com facilidade em fontes não clínicas, o que possivelmente explica o feito surpreendente de que no começo, e inclusive posteriormente, discutiram-se mais problemas de arte, literatura, mitologia, religião e educação que problemas psiquiátricos propriamente ditos.

Como nos revela Plon (1999), já em 1907 o projeto da psicanálise aplicada torna-se um ramo da atividade psicanalítica: ganha o direito à criação de uma coleção intitulada Schriften zur angewandten Seelenkunde (Monografias de psicologia aplicada), cujo volume inaugural é constituído pelo ensaio de Freud sobre a Gradiva de Jensen. Seguem-se os trabalhos de Jung, Abraham, Pfister, Jones, Hermine vom HuggHellmuth e o texto de Freud sobre Uma lembrança infantil de Leonardo da Vinci (1910/1996a). Só por essa lista ${ }^{9}$, diz Plon (1999), seria possível ter uma ideia da importância do empreendimento.

Segundo Freud (1907/1996, p.227), os Schriften zur angewandten Seelenkunde, dirigem-se:

\begin{abstract}
àquele amplo círculo de pessoas instruídas que, sem serem realmente filósofos ou médicos, estimam as ciências da mente humana por sua importância na compreensão e no aprimoramento de nossas vidas. Os artigos não serão publicados numa ordem predeterminada, mas sempre apresentarão em cada caso um único estudo sobre a aplicação de conhecimentos psicológicos a temas artísticos e literários, à história das civilizações e religiões, e a outros setores análogos. Esses trabalhos terão algumas vezes o caráter de investigações exatas, outras vezes o de esforços especulativos, ora tentando abranger questões mais amplas, ora tentando aprofundarse num tema mais restrito.
\end{abstract}

É interessante notar a quem Freud endereça essas publicações. Ele não as restringe aos psicanalistas: elas estão voltadas a todos aqueles que se interessam pelas ciências humanas. Nesse sentido, podemos pensar que essa publicação é um alicerce importante para a disseminação da psicanálise. Chama a atenção também a suposição de que seriam ora investigações exatas, ora esforços especulativos. Não fica claro o que Freud quer dizer com isso.

Nas correspondências com Carl Gustav Jung, como apresenta Mcguire (1993), Freud compartilha seu interesse pela arqueologia e a mitologia, assim como

\footnotetext{
$9 \quad$ A lista dos autores e suas respectivas produções na Schriften zur angewandten Seelenkunde, até 1913,
} consta na p. 588 de A correspondência Completa de Sigmund Freud e Carl G. Jung (1974/1993). 
a intenção de expandir a psicanálise. Desse modo, esse fazer psicanalítico ganha o caráter de um "trampolim" para a inserção do pensamento freudiano na cena científica da época.

No entanto, essa ida a outros campos não poderia se dar de forma leviana. Como revela Jung, em 14 de outubro de 1909, diante da ideia de eventualmente escrever um texto que abarcasse todo esse campo (mitologia), seriam necessários anos de preparo e levantamento de fatos, sublinhando o imperativo de atacar em várias frentes. A arqueologia, ou mais propriamente a mitologia, seria uma mina de materiais fantásticos.

Freud, em resposta no dia 17 outubro de 1909, demonstra satisfação em saber que Jung compartilha sua crença de que eles devem conquistar por completo o campo da mitologia. Até aquele momento eles teriam apenas dois pioneiros: Abraham e Rank. Não seria fácil encontrá-los, Freud e Jung precisariam de homens para campanhas mais longas. Freud ainda indica que conviria também entrar pelo domínio biográfico. Ele revela ter tido uma inspiração em que o enigma do caráter de Leonardo da Vinci teria se tornado subitamente claro. Com isso, ele poderia dar um primeiro passo no domínio da questão. Em 11 de novembro de 1909, Freud aponta que a solidão já não seria tanta, e mostra-se ansioso para saber das descobertas de Jung.

Freud encontra em Jung um aliado para as suas ideias de expansão. No entanto, o caminho a ser empreendido em direção a outros campos necessitaria de outros auxiliares. No dia 19 do mesmo mês, como revela Mcguire (1993), Freud, em meio a considerações sobre o Jahrbuch, afirma que os colonizadores em outras terras, como Pfister, deveriam também se apresentar. Ele revela ansiar por mitólogos, linguistas e historiadores da religião. Chama atenção a palavra utilizada por Freud: "colonizadores". Esse intento, assim, ganha não só ares de uma conquista de territórios novos, mas também pode levantar o sentido de subjugação, considerando a psicanálise uma teoria mestra.

Em meio a esse empreendimento de expansão, seja a partir da psicanálise voltada para outros campos, seja da própria terapêutica e da teoria psicanalítica, como aponta De Certeau (1987/2011) em 1910 cria-se a "Associação Psicanalítica Internacional" (IPA), dotada de um "chefe", equipada com recursos de controle e destinada a "facilitar a ajuda mútua entre seus membros" (apud De Certeau, 2011, 
p.120-121). Vale lembrar, como já mostrado neste trabalho acerca da psicanálise selvagem, que a IPA tinha como objetivo garantir que a Psicanálise se resguardasse de impostores que pudessem macular ou prejudicar a causa psicanalítica, a saber, a sua transmissão.

Segundo De Certeau (1987/2011, p. 79), a criação da IPA:

[...] não impediu que essas pesquisas (em particular, como afirma Freud, "as aplicações da psicanálise à ciência da linguagem e à história") se diferenciassem e, até se confrontassem cada vez mais. Parece haver, nessas divergências, um papel mais importante desempenhado por três elementos (precisamente históricos): 1. A relação dos autores com a pessoa de Freud (a teoria analítica tem como fundamento a irracionalidade e a particularidade de uma transferência sobre o outro e, portanto, a singularidade da psicologia de Freud); 2. A relação de dependência entre uma teoria da história e a elucidação, pela análise, de sua relação com a instituição psicanalítica (essa associação submete seus membros à lei de qualquer sociedade - aspecto, frequentemente, dissimulado pela teoria); 3. A lógica das situações sociopolíticas nacionais em que a posição do analista "sujeito suposto saber" pôs-se a funcionar (a pressão social é mais forte do que a "família" freudiana ou do que uma sociedade internacional).

Assim, as tentativas de colocar fronteiras para a psicanálise mostram-se falhas, na medida em que o próprio movimento psicanalítico testa esses limites.

Em pouco tempo, segundo Plon (1999), a Schriften zur angewandten Seelenkunde (Monografias de psicologia aplicada) teria se revelado estreita demais para garantir o desenvolvimento de um setor em plena expansão. Nasceria então a ideia de uma revista inteiramente dedicada aos trabalhos da psicanálise aplicada. Em 1912, como afirma Gay (1989), junto com Hanns Sachs, Otto Rank fundou Imago $^{10}$, um periódico especializado, como anunciava o cabeçalho, na aplicação da psicanálise às ciências da cultura.

Segundo Gay (1989, p. 291):

Freud, de início, estava preocupado que, embora editada por "dois rapazes inteligentes e honestos", a Imago não viesse a "ter uma

10 Segundo Otto Rank: “o título da nova publicação deu-nos algumas dores de cabeça. Finalmente, prevaleceu a minha sugestão e foi chamada Imago, inspirada na novela de Carl Spitteler, na qual os artifícios e máscaras do inconsciente, invadindo a consciência e estimulando forças criativas, são apresentados com consumada maestria”. (1944, apud Mcguire, 1974/1993, p.485). 
carreira tão fácil como a que se apresentou aos outros órgãos". Suas apreensões mostraram-se injustificadas. A Imago, podia informar Freud em junho de 1912, "está indo admiravelmente bem".

Como revela Gay mais adiante (1989, p.291):

Os editores encontravam por toda parte psicanalistas mais do que dispostos a colaborar, e entre eles nada menos que o próprio Freud. Ele supervisionava os "dois rapazes inteligentes e honestos", e enviou-lhes alguns de seus artigos exploratórios mais ousados.

Freud editaria ali as primeiras versões de Totem e Tabu, bem como seu estudo sobre $O$ Moisés de Michelangelo, textos que revelam um salto em relação às produções feitas até então.

Reconhecidamente, afirma Gay (1989, p. 291):

algumas patografias de artistas e poetas produzidas no círculo vienense eram ingênuas e precipitadas, e por vezes suscitavam a irritação manifesta de Freud. Mas, bem ou mal feita, a psicanálise aplicada foi, quase desde o seu início, um risco coletivo.

Sendo assim, esse empreendimento não estava livre de imprecisões ou mesmo de produções equivocadas, o que leva à ideia de se tratar de um risco a todos aqueles que adentram nessa seara.

A respeito da Imago, Freud afirma que (1916/1996, p.169):

No trabalho da psicanálise formam-se vínculos com numerosas outras ciências mentais, cuja investigação promete resultados do mais elevado valor: vínculos com a mitologia e a filosofia, com o folclore com a psicologia social e com a teoria da religião. Os senhores não ficarão surpresos ao ouvir que uma revista cresceu em solo psicanalítico e seu único objetivo é fortificar esses vínculos.

A criação dessas duas publicações científicas (Schriften zur angewandten Seelenkunde e Imago) com o propósito específico de difusão das reflexões psicanalíticas voltadas para outros campos do saber, bem como as considerações feitas por Freud a respeito delas, revela a grande importância que o autor confere a essa face da Psicanálise. Ela ganha o papel de fortificar os vínculos com intelectuais de outras áreas das ciências humanas. 
Segundo Plon (1999), vale ressaltar, além destas etapas institucionais, o espírito de conquista épica que seria o empreendimento, testemunhado por inúmeras reflexões favorecidas pela espontaneidade da atividade epistolar. No entanto, o entusiasmo assim manifestado também tinha sua contrapartida em declarações mais prudentes, ou até mesmo reticentes quanto a certos desenvolvimentos da psicanálise aplicada.

Um exemplo é a publicação anônima na Imago, por desejo de Freud, do seu escrito O Moisés de Michelangelo. Segundo Gay (1989), embora Freud tenha revelado que gostara muito das palavras que de fato escreveu nesse texto, optou por não identificar a sua autoria. A esse respeito, o autor (1989, p. 293) indica que:

Abraham teria perguntado a Freud: "O senhor não acha que se
reconhecerão as marcas do leão?". Freud, no entanto, teria insistido
em chamar o artigo de "um filho bastardo". Em março de 1914, logo
depois que Moisés voltara da gráfica, Freud ainda perguntava a "seu
caro Jones": "talvez seja melhor não reconhecer esse filho perante o
público", e não reconhecido ele se manteve por dez anos. Mas ele o
apreciava quase tanto quanto a estátua analisada.

Freud (1969) apud Plon (1999) falando desse texto a Karl Abraham, escreve: "O Moisés é anônimo, de um lado, por brincadeira, de outro, porque tenho vergonha do seu evidente caráter diletante, do qual é difícil fugir quando se escreve para a Imago; enfim porque, mais que habitualmente, duvido dos resultados e só publiquei pressionado pela redação". Freud sentia-se como um amador que se debruçava em outros campos. Como um estrangeiro, ele lançou-se nessa empreitada, tendo em vista que era como psicanalista que ele adentrava em outros territórios.

A ambiguidade em relação a essas produções é evidenciada também em cartas trocadas por Freud e Ferenczi acerca da publicação de Totem e Tabu. Em 8 de maio de 1913, ele aponta que desde a $A$ Interpretação dos Sonhos não escrevera nada com semelhante convicção; assim, podia prever o destino deste ensaio. Em 13 de maio de 1913, Freud novamente aproxima Totem e Tabu de A Interpretação dos Sonhos, e acrescenta que a recepção seria correspondente, a seus olhos, a uma tempestade de indignação, excluindo seus seguidores mais próximos, o que soa paradoxal.

É interessante notar como Freud refere-se à leitura de Totem: "Quem quiser 
beijar a princesa que dorme lá dentro, deverá, seja como for, dar-se ao trabalho de ultrapassar algumas cercas de espinhos de bibliografia e referências" (1995, p. 210). Dias depois, em 12 de junho de 1913, ele afirma que após os espinhos, atrás dos quais dorme a princesa, haveria passagens mais interessantes; infelizmente, também algumas mais pobres. Freud indica, ainda, que recuou muito de sua superestimação inicial do trabalho e estaria, no conjunto, preocupado.

Freud parece aqui compartilhar o percurso espinhoso pelo qual teve que passar na escrita desse texto. É possível que ele tenha se referido ao intenso trabalho que empreendeu para se aproximar da antropologia. Somente depois disso pôde chegar a suas hipóteses fundamentais, à "princesa que dorme depois dos espinhos".

Em 23 de junho de 1913, Ferenczi responde a Freud e revela que a impressão que teve do trabalho de Totem foi extraordinariamente profunda, embora já conhecesse a maioria dos raciocínios. Ele também pede que Freud não introduza atenuações, e deixe tudo como estava na prova de Totem. A argumentação seria perfeita e não deixaria margem a dúvidas. Ele propõe ainda que a hesitação posterior de Freud seria, na verdade, um deslocamento da submissão a posteriori aos pais (seu próprio pai), aos quais, neste trabalho, Freud faria perder os últimos restos de poder.

Vale lembrar também com Plon (1999) que, no tempo em que evocava com Jung os impérios a conquistar, Freud não hesitou em escrever, como se o tamanho da tarefa e seus perigos o assustassem: "[...] não passamos de miseráveis diletantes. Precisamos urgentemente de auxiliares hábeis [...]" (p.97). É importante destacar esse último ponto, visto que ele caracteriza muito bem a posição em que se coloca o analista quando se dirige para outro campo: como um diletante, nas palavras de Freud, ou seja, quem pratica uma arte, um ofício como um passatempo, e não como um meio de vida; um amador.

Acerca das biografias, tanto Jones (1989) como Gay (1989) dedicam-se a apresentar o interesse de Freud e seus percalços no seu diálogo com outros campos do saber.

Gay (1989) inicia afirmando que a palestra de Freud, realizada em 1907, que deu origem ao texto Escritores Criativos e Devaneios, teria sido sua primeira 
tentativa de aplicar ideias psicanalíticas à cultura, salvo poucas considerações em $A$ Interpretação dos Sonhos. De acordo com o autor, o referido texto seria uma contribuição séria à estética psicanalítica.

Em seguida, o biógrafo destaca que, entre os anos de 1909 e 1910, Freud focava a sua atenção na psicanálise em direção a outros campos. Segundo o Gay (1989, p. 289):

Hanns Sachs, que conheceu Freud nessa época, pouco exagerou ao
afirmar que o via "dominado por uma ideia despótica", uma
dedicação ao trabalho que sua família suportava "com a maior
disposição, sem um resmungo". Sua concentração nesses dias
eufóricos era, talvez, maior do que nunca: era o momento de levar a
psicanálise para fora do consultório.

Segundo Gay (1989), o que ele diz ao socialista flamengo dissidente Hendrick de Man, em 1925, era sua firme convicção há quinze anos: "sempre fui da opinião de que as aplicações extramédicas da psicanálise são tão significativas quanto as médicas, e na verdade aquelas talvez possam ter uma influência maior sobre a orientação mental da humanidade" (p.290).

O biógrafo aponta que Freud ainda tinha momentos de hesitação ou incerteza, embora estes se tornassem progressivamente mais raros. Mesmo Freud tendo uma destacada capacidade autocrítica da qual se orgulhava ou até se vangloriava, as perspectivas de uma interpretação psicanalítica deixavam-no eufórico. Ele tinha certeza que aí residia sua próxima tarefa.

Como destaca Gay (1989, p.289):

Em 1913, ao resumir o trabalho de explanação já realizado pela psicanálise fora do consultório, ele esboçou um ambicioso programa de novas conquistas. A psicanálise, afirmou ele, pode lançar raios de luz sobre as origens da religião e da moral, da justiça e da filosofia. Agora, "a história da cultura" estava apenas à espera de seu intérprete psicanalítico.

Sendo assim, não há dúvidas da importância e alcance que Freud esperava das produções em direção a outros campos. Gay (1989) revela também que alguns dos artigos de Freud, de fato, eram rápidas incursões inconclusivas por outras áreas do conhecimento nas quais não era especialista. Mas, por outro lado, segundo 
Freud, os profissionais de outros campos por algum motivo não se aproximavam das reflexões produzidas pelos psicanalistas.

É importante notar também, segundo Gay (1989, p. 290), que: "Freud nunca duvidou que o sujeito inteligente que deduziria as consequências culturais da psicanálise era ele próprio". Além disso, descreve o autor: "o que the importava não era tanto o que poderia aprender com a história da arte, a linguística e as demais disciplinas, mas o que elas poderiam aprender com ele" (p. 291).

A partir desse ponto, o biógrafo discorre acerca das produções psicanalíticas voltadas para a estética e a literatura, a saber, respectivamente, seu texto sobre a estátua de Moisés de Michelângelo e sobre a Gradiva de Jensen, para, então, apresentar o item acerca das fundações da sociedade. Gay (1989) destaca, também, que a aplicação por Freud de suas descobertas à escultura, à ficção e à pintura teria sido bastante audaciosa. Mas ela se tornaria pálida frente à sua tentativa de escavar as fundações mais remotas da cultura. $O$ autor se refere ao conjunto de quatro ensaios, Totem e Tabu. Para ele, esse texto seria não apenas psicanálise aplicada, mas também um documento político.

Em seguida, Gay (1989, p. 311) indica que Freud considerava que:

suas investidas intelectuais [sobre a arte, literatura e pré-história] não eram digressões, nem desvios de seu trabalho teórico fundamental. Uma preocupação alimentava as outras. Os casos clínicos levaramno a questões da cultura; e as reflexões sobre a criação literária reconduziram-no ao Complexo de Édipo. Assim, apesar de todas as variadas demandas sobre seu tempo, Freud nunca descurou do que considerava sua tarefa principal: aperfeiçoar seu mapa da mente.

Dessa maneira, não haveria uma dicotomia entre teoria/clínica e psicanálise aplicada. Nos anos que antecederam à Primeira Guerra, segundo Gay (1989), haveria um caráter bifronte dos textos de Freud, visando a uma súmula e preparando uma revisão. Depois da eclosão da guerra, tomado pelo rumo dos acontecimentos, Freud publicou um par de artigos sobre a desilusão gerada pela guerra e sobre a atitude moderna em relação à morte, revelando, assim, sua relação com seu tempo histórico.

A partir da Biografia de Freud escrita por Peter Gay, buscou-se tanto delinear o percurso do texto quanto recolher alguns trechos que se dirigiam claramente à 
questão da psicanálise aplicada. No geral, foi possível notar a importância desse empreendimento para Freud. Era o momento de levar a psicanálise para fora do consultório, e ele esboçava um ambicioso programa de conquistas. Chegou a conceber que talvez as aplicações extramédicas da psicanálise pudessem ter uma influência maior sobre a orientação mental da humanidade do que aquela voltada para a terapêutica.

Na biografia escrita por Gay, é possível recolher mais indícios do caráter ambicioso desse fazer. De todo modo, assim como evidenciado a partir das formulações do próprio Freud anteriormente nesse trabalho, essa empreitada era acompanhada ora de euforia, ora de hesitação. No entanto, o biógrafo também indica que esses momentos de hesitação estavam rareando cada vez mais.

Vale destacar ainda a posição de Gay, ao apontar que, embora Freud realizasse essas análises acerca da cultura, ele centrava-se em aperfeiçoar seu mapa da mente. Assim, esses dois âmbitos se cruzavam na construção teórica freudiana.

Chamou também a atenção o destaque dado pelo biográfico de Freud ao texto Totem e Tabu, o qual teria um alcance muito superior se comparado a outros colocados no grupo da psicanálise aplicada. Gay (1989, p.290) indica que: "alguns dos artigos de Freud eram rápidas incursões inconclusivas por campos onde ele não se considerava especialista"; quanto ao Totem, afirma-se que ele seria psicanálise aplicada, mas também um documento político. Por fim, coloca-se a produção teórica de Freud em tempos de guerra. Em meio à desilusão e à catástrofe, Freud não se manteve alheio a seu tempo histórico e produziu dois importantes artigos.

O biográfico e psicanalista Ernst Jones (1989) dedica-se, no terceiro volume da biografia de Freud, à interface da psicanálise com outras áreas do saber. São elas: biologia, antropologia, sociologia, religião, ocultismo, arte e literatura. E escreve um capítulo intitulado Retrospecto, em que avalia a influência de Freud no mundo, separando sua exposição em alguns itens: psiquiatria, criminologia e vida social.

Em geral, as considerações do biógrafo são descritivas e não apresentam as nuances do movimento psicanalítico. De todo modo, ele trata pormenorizadamente das produções freudianas nos vários campos e apresenta-as no contexto dos interesses freudianos.

No que se refere à antropologia, Jones (1989) aponta que Freud foi 
basicamente um descobridor, e seu interesse sempre se voltou para problemas que ofereciam alguma promissora abertura para investigação. Como tudo o que aprendera sobre a mente humana proviera da busca de seu desenvolvimento passado, ele pensava que essa seria a principal fonte de nosso conhecimento.

Para Freud, o homem seria sempre impelido para adiante pelo passado e, no entanto, arrastado de volta em sua direção. Portando, segundo Jones (1989), tudo isso dirigia necessariamente os interesses de Freud para o passado, seja do indivíduo, seja da humanidade como um todo; como ilustram as alusões à Antiguidade, espalhadas por toda a obra de Freud. O autor destaca que Freud empregava-as na investigação de problemas analíticos, particularmente de material literário.

Outro aspecto levantado por Jones (1989) é que Freud também penetrou na significação interna dos mitos, lendas e contos de fadas. O pai da psicanálise comparou os mitos a "sonhos seculares", isto é, sonhos despertos que ocupam a imaginação das pessoas ao longo de gerações. Ele destaca, também, que Abraham, Rank, Riklin e muitos outros, desde então, fizeram amplo uso dos métodos de Freud para estudar esses produtos da imaginação humana.

Depois de falar sobre arqueologia e mitologia, Jones (1989) discorre sobre o campo da antropologia social. Nesse ponto ele destaca, como era de se esperar, o texto Totem e Tabu (1913). Várias páginas são dedicadas à obra; o biógrafo relata que esse trabalho pode ser considerado uma contribuição tanto para a sociologia quanto para a antropologia.

No entanto, o autor aponta também que por muitos anos as contribuições freudianas à antropologia foram rejeitadas, desdenhadas e com frequência recebidas com incômodo pela grande maioria dos antropólogos em todos os países. Por muito tempo, afirma Jones (1989), o único antropólogo que teria apoiado Freud teria sido Géza Róheim, que tinha a vantagem de possuir experiência de campo, bem como formação psicanalítica. Entretanto, segundo o biógrafo, após a Segunda Guerra Mundial, haveria comprovações de que as teses freudianas eram mais consideradas pelos antropólogos.

Quanto à sociologia, Jones (1989) aponta que Freud teria sido reprovado, de modo absolutamente injustificável, por negligenciar os aspectos sociais da vida de 
seus pacientes. No entanto, segundo o biógrafo, ainda em 1905, no primeiro caso clínico analítico que publicou, teria escrito que, a julgar pela natureza dos fatos que formam o material da psicanálise, seríamos obrigados, em nossos casos clínicos, a dar tanta atenção às circunstâncias puramente humanas e sociais de nossos pacientes quanto aos dados somáticos e aos sintomas de perturbação. Jones (1989) afirma ser verdadeiro que suas conclusões baseavam-se na psicologia do indivíduo, mas teria sido Freud, mais do que ninguém, que teria ensinado que qualquer aspecto do indivíduo seria realmente um aspecto social.

O psicanalista inglês discorre ainda nesse item sobre os livros: Totem e Tabu (1913); Psicologia de grupo e análise do Ego (1921); e o Mal-estar na Civilização (1930), que seria a mais completa exposição de Freud de suas concepções no campo da sociologia. Segundo Jones (1989), esse último texto não poderia ser outra coisa senão psicologia aplicada. As contribuições de Freud para a sociologia tiveram uma recepção muito mais amistosa que suas contribuições para a antropologia.

No que se refere à religião, o biógrafo trata das principais obras de Freud nessa direção: Totem e Tabu (1913), Psicologia de grupo e análise do Ego (1921), 0 futuro de uma ilusão (1927) e Moisés e o Monoteísmo (1939). Ele aponta que uma das críticas feitas ao texto $O$ futuro de uma ilusão era de que Freud não tinha 0 direito de postular a propósito de um campo de pensamento que não era o seu, conhecida objeção feita em outras ocasiões, como, por exemplo, em relação à arte e antropologia. Jones discorre ao longo de muitas páginas a respeito de Moisés e o Monoteísmo.

Em relação à arte, de acordo com Jones (1989), Freud estava muito mais interessado na arte literária do que na pictórica ou escultórica; seria significativo que, em seus textos sobre Leonardo e Michelangelo, não tenha abordado de forma direta o tema da apreciação estética. E acrescenta que uma palavra poderia ser dita sobre o efeito da psicanálise na inspiração artística. Os artistas frequentemente demonstraram um misto de interesse e apreensão por esse assunto. Isso teria se mostrado de duas formas opostas e, na verdade, contraditórias. Por um lado, advertiram os analistas contra a tentativa de penetrar em seus segredos. De outro, contudo, aconselharam com veemência que nenhum artista fosse analisado, com medo de que a inspiração de sua arte fosse destruída, embora jamais tenham explicado por que apenas essa capacidade em especial deva ocorrer risco tão 
terrível.

Quanto à literatura, afirma Jones (1989), o primeiro exemplo de estudo psicanalítico de uma produção literária, estudo que Freud nunca publicou, ocorre na correspondência com seu amigo Fliess. Nesse documento, ele teria se dedicado a uma interpretação analítica dos motivos da narrativa Die Richterin, de Conrad Ferdinand Meyer. O primeiro exemplo publicado foi nada menos que a conhecida interpretação que Freud fez de Hamlet, na qual elucidou o antigo mistério, reduzindo a tragédia a uma variante da situação edipiana. Transmitira suas conclusões a Fliess alguns anos antes, na mesma época de sua descoberta do Complexo de Édipo.

Jones (1989), então, lista as contribuições seguintes de Freud ao estudo da criação imaginativa. Em 1906, o pequeno artigo Tipos Psicopáticos do Palco, que cuida das condições sob as quais certas formas de arte, em particular o teatro, afetam um público e como alcançam seu propósito; em 1907, Freud dera um exemplo de como os autores podem achar útil a realização de atos sintomáticos inconscientes. No ano seguinte, publicou a Gradiva. Um ano depois, escreveu Escritores criativos e seus devaneios. Em 1913, voltou a seu favorito Shakespeare, no ensaio O Tema dos Três Escrínios. Dois anos depois, Freud tentou deslindar duas outras peças de Shakespeare, mas dessa vez com menos sucesso manifesto. Sua última contribuição à psicologia da literatura apareceu muito depois, em 1928. Desta vez o autor estudado foi Dostoiévski.

Jones (1989), assim, apresenta um cuidadoso percurso pelas diversas produções freudianas em diferentes áreas. Vale destacar, no entanto, alguns aspectos: o biógrafo indica, em cada uma delas, em que medida a psicanálise foi criticada e também reconhecida nesse diálogo. É importante notar que a única vez em que Jones menciona a psicanálise aplicada é quando considera que O Mal-Estar na Civilização estaria nesse grupo de produções.

Chega-se, então ao final desta seção. Não restam dúvidas sobre a importância das incursões da psicanálise em relação a outros campos, tantas foram as considerações de Freud nesse sentido. Foi possível não só evidenciar seu interesse por outras áreas, mas compreender de que forma essas reflexões inseremse na teoria psicanalítica.

Além disso, é importante destacar o movimento de expansão buscado por 
Freud, que queria se firmar como um grande pensador. A incursão a outros campos do conhecimento trazia consigo a possibilidade de Freud inserir-se num âmbito mais amplo da ciência. Freud apostava em sua fecundidade para os outros saberes, mas não escondia em alguns momentos que a psicanálise daria mais do que receberia e que estava em jogo a conquista de novas terras. Nesse ponto, vale destacar o desejo colonizador de Freud, que traz à tona o fato de que essas incursões psicanalíticas deixam espaço ou brechas para que a psicanálise coloque-se como teoria mestra, ganhando assim um caráter educativo.

Não seriam poucas as críticas feitas a essa face da psicanálise. De todo modo, parece que a transmissão da psicanálise estava em questão para Freud, que não escondia transitar como um diletante para esses territórios estrangeiros.

Por fim, outro ponto a ser lembrado é a variedade de produções realizadas e os muitos campos com os quais a psicanálise faz fronteira. É preciso ainda frisar que essas produções feitas em diferentes momentos da obra freudiana guardam muitas diferenças não só no que refere à área visitada, mas em seus objetivos e alcance teórico.

\subsection{A Herança Freudiana}

A partir de uma pesquisa que consistia em investigar, entre os vários textos freudianos, aqueles que tratavam de alguma maneira do termo psicanálise aplicada ou aplicações da psicanálise, pode-se encontrar o seguinte conjunto de escritos: Prospecto para Schriften Zur Angewandten Seelenkunde (1907), Leonardo da Vinci e uma lembrança da sua infância (1910), O interesse científico da psicanálise (1913), A história do movimento psicanalítico (1914), Conferência $X$ - Simbolismo nos sonhos (1916), Sobre o Ensino da Psicanálise nas Universidades (1919), Uma breve descrição da Psicanálise (1924), Dois verbetes de Enciclopédia (1923), A questão da análise leiga (1926), Explicações, Aplicações e Orientações (1933a), Novas conferências introdutórias sobre a psicanálise (1933b) e Prefácio a A vida e as obras de Edgar Allan Poe: uma interpretação psicanalítica de Marie Bonaparte (1933c). Depois de ler esses textos e considerá-los em seu conjunto, chamam a atenção alguns pontos que serão apresentados a seguir.

De modo geral, o que Freud revela é a amplitude que a psicanálise alcança a 
partir de suas formulações fundamentais. Em vários dos textos citados, é possível acompanhar essa construção e, nesse sentido, o texto A Interpretação dos Sonhos mostra-se fundante. Nas palavras de Freud (1914/1926):

\begin{abstract}
A maior parte dessas aplicações da análise remonta, sem dúvida, a uma sugestão feita em minhas primeiras obras analíticas. O exame analítico de pessoas neuróticas e os sintomas neuróticos de pessoas normais me levaram a supor a existência de condições psicológicas que haveriam de ultrapassar a área do conhecimento na qual tinham sido descobertos. Sendo assim, a análise nos proporcionou não somente a explicação de manifestações patológicas, como revelou sua conexão com a vida mental normal e desvendou relações insuspeitadas entre a psiquiatria e as demais ciências que lidam com a atividade da mente (p. 44).
\end{abstract}

Interessa salientar nesse trecho o caminho apontado por Freud, que começa pela neurose, passa pela vida normal e termina com a possibilidade de estabelecer relações com as ciências mentais, chamadas hoje de ciências humanas. Os fios condutores desse percurso são certas condições psicológicas, as quais supomos, pelo contexto, tratarem-se dos processos inconscientes. Ao fazer essa relação, Freud considera ser inevitável que a apreensão do inconsciente ultrapasse a área de conhecimento na qual foi descoberto.

Anos depois, no mesmo sentido, o autor aponta que:

Qualquer estimativa da Psicanálise estaria incompleta se deixasse de tornar claro que, sozinha entre as disciplinas médicas, ela possui as mais amplas relações com as ciências mentais e se encontra em posição de desempenhar um papel da mesma importância nos estudos da história religiosa e cultural e nas ciências da mitologia e da literatura que na psiquiatria. Isso pode parecer estranho quando refletimos que originalmente seu único objetivo era a compreensão e a melhoria dos sintomas neuróticos. Mas é fácil indicar o ponto de partida da ponte que conduz às ciências mentais. A análise dos sonhos forneceu-nos uma compreensão dos processos inconscientes da mente e demonstrou-nos que os mecanismos produtores dos sintomas patológicos operam também na mente normal. Assim, a psicanálise tornou-se uma psicologia profunda e, como tal, capaz de ser aplicada às ciências mentais, e pôde responder a um bom número de questões que a psicologia acadêmica da consciência era impotente para tratar (FREUD, 1923/1996, p. 268). 
É possível notar, nesse ponto, que Freud situava a psicanálise num posto diferenciado dentre as ciências médicas na medida em que alcançava também o amplo campo das ciências do espírito. A incursão da psicanálise a outras áreas do saber teria como divisor de águas a análise dos sonhos, a partir da qual teria sido possível chegar à compreensão dos processos inconscientes e, nesse sentido, inaugurar-se-ia uma psicologia profunda, que permitiria a ida às ciências humanas, argumento também trazido no trecho anterior.

$\mathrm{Na}$ mesma linha dessas considerações, em $A$ questão da Análise Leiga, Freud afirma que:

Como uma 'psicologia profunda', uma teoria do inconsciente mental, pode tornar-se indispensável a todas as ciências que se interessam pela evolução da civilização humana e suas principais instituições como a arte, a religião e a ordem social. Em minha opinião ela já proporcionou a essas ciências considerável ajuda na solução de problemas. Mas essas são apenas pequenas contribuições em confronto com o que poderia ser alcançado se historiadores da civilização, psicólogos da religião, filósofos e assim por diante concordassem em manejar o novo instrumento de pesquisa que está a seu serviço (1926, p. 238).

O acréscimo fornecido por esse trecho é o destaque para a possibilidade de a psicanálise tornar-se indispensável para as ciências dedicadas a pensar sobre as principais instituições humanas. O criador da psicanálise pontua também que essa interface seria ainda incipiente se considerado o que poderia ser alcançado, caso estudiosos de diversas áreas do conhecimento se aproximassem desse fazer.

Mais ao final de sua obra, Freud afirma que (1933a/1996):

Depois, no entanto, percebemos as estreitas relações, a própria identidade interna entre processos patológicos e aquilo que se conhece como processos normais. A psicanálise tornou-se psicologia profunda; e, de vez que nada daquilo que o homem cria ou faz, é compreensível sem a cooperação da psicologia, as aplicações da psicanálise a numerosas áreas do conhecimento, em especial àquelas das ciências mentais, ocorreram espontaneamente, entraram em cena e requerem debate (p. 143).

Freud aponta não só para uma expansão da Psicanálise, mas para um alcance promissor. E, em alguns momentos, sem fazer muito alarde, aponta que ela produziria saberes inevitavelmente importantes para as outras áreas. Vale notar que 
essa propriedade da teoria psicanalítica já era enunciada anos antes.

No texto Sobre o Ensino da Psicanálise nas Universidades, ao discorrer sobre a importância da psicanálise para a totalidade da formação médica e acadêmica, ele declara que ela se fundamentaria em alguns fatos, um dos quais seria o exposto a seguir:

\begin{abstract}
$\mathrm{Na}$ investigação dos processos mentais e das funções do intelecto, a psicanálise segue seu próprio método específico. A aplicação desse método não está de modo algum confinada ao campo dos distúrbios psicológicos, mas estende-se também à solução de problemas da arte, da filosofia e da religião. Nessa direção já produziu diversos novos pontos de vista e deu valiosos esclarecimentos a temas como história da literatura, a mitologia, a história das civilizações e a filosofia da religião. Assim, o curso psicanalítico geral seria também aberto aos estudantes desses ramos do conhecimento. Os efeitos fecundadores do pensamento psicanalítico sobre outras disciplinas certamente contribuiriam muito para moldar uma ligação mais estreita, no sentido de uma universitas literarum, entre a ciência médica e os ramos do saber que se encontram dentro da esfera da filosofia e das artes (FREUD, 1919/1996, p.188).
\end{abstract}

É importante notar que o psicanalista vienense considera que os efeitos produzidos nas outras disciplinas propiciariam o estreitamento dos laços entre estas e a psicanálise e, dessa forma, a disseminação do saber psicanalítico.

Em outro escrito, Freud diria também:

Podemos, assim, expressar nossa expectativa de que a psicanálise, cujo desenvolvimento e realizações até o presente foram sucinta e inadequadamente relatados nessas páginas, ingressará no desenvolvimento cultural das próximas décadas como um fermento significativo e auxiliará a aprofundar nosso conhecimento do mundo e a lutar contra algumas coisas da vida, reconhecidas como prejudiciais (1924/1996, p. 233).

Fica evidenciada, nessa passagem, a aposta feita pelo autor em relação às produções psicanalíticas voltadas para aspectos da vida cultural. Não se pode esquecer ainda, nesse sentido, do texto $O$ interesse científico da psicanálise (1913). Esse artigo foi escrito por Freud a pedido expresso do redator-chefe da Scientia, conhecido periódico científico italiano. Trata-se de uma descrição ampla que ele fez das aplicações não médicas da psicanálise. O autor apresenta o interesse da psicanálise ao Filológico, Filosófico, Biológico, Desenvolvimento, História da Civilização, Ciência Estética, Sociológico e Educacional. 
Freud também nos lembra, ao longo dos seus vários textos, da importância de que especialistas dessas outras áreas do conhecimento se aproximem da psicanálise e desse fazer. Em A história do movimento psicanalítico (1914), ele destaca que até aquele momento poder-se-ia dizer que pouco trabalho havia sido feito. No entanto, Freud alerta que isso ocorreria por existir muito trabalho para um pequeno número de trabalhadores.

Mais adiante nesse texto, ele afirma:

Com este esboço incompleto tentei dar uma ideia da riqueza ainda incalculável de conexões que surgiram entre a psicanálise médica e outros campos da ciência. Existe aí material de trabalho para uma geração de pesquisadores, e não duvido de que ele será realizado tão logo as resistências contra a psicanálise sejam superadas em seu campo de origem. (FREUD, 1914/1996, p.47)

É importante lembrar que ele registra essas resistências não só no âmbito da psicanálise, mas nos outros campos do saber:

também não faltou hostilidade da parte de pessoas que nada sabiam da psicanálise, apresentando as mesmas manifestações que ocorreram no campo original da pesquisa psicanalítica - as mesmas concepções errôneas e rejeições veementes. Era de esperar-se desde 0 início que, quaisquer que fossem as regiões em que a psicanálise penetrasse, ela teria inevitavelmente de enfrentar as mesmas lutas com os donos dos campos. (Ibidem, p.45)

Vale dizer que, em certos momentos (1933a/1996, p.143), o próprio Freud, sem deixar de lado seu entusiasmo, mostra ressalvas quanto à psicanálise aplicada:

Uma aplicação desse tipo pressupõe conhecimento especializado, que um analista não possui, ao passo que aqueles que possuem, os especialistas nada conhecem da análise, e talvez nada queiram conhecer. Como resultado, analistas como amadores lidando com um equipamento dotado de maiores ou menores recursos, muitas vezes reunidos às pressas, fizeram incursões em áreas do conhecimento tais como mitologia, história da civilização, etnologia, ciência da religião, etc. Foram tratados pelos peritos dessas áreas de forma não melhor que são os infratores em geral: seus métodos e descobertas, na medida em que chamavam atenção, foram liminarmente rejeitados. Essas situações estão melhorando constantemente, e em toda parte há um crescente número de pessoas que estudam psicanálise a fim de utilizá-los em seus setores especializados (...). Aqui podemos esperar uma abundante colheita de novos descobrimentos. 
Esse trecho condensa muitas questões. Inicialmente, Freud levanta um impasse, a saber, que muitos analistas acabam realizando reflexões em áreas do conhecimento nas quais não são especialistas, e aqueles que poderiam realizá-las com propriedade nada conhecem da análise e, tampouco, querem vir a conhecer. Em acréscimo a essa impressão, Freud aponta que muitos dos trabalhos realizados pelos analistas acabam sendo recebidos com contrariedade pelos peritos dessas disciplinas. Esses tratariam os psicanalistas, em geral, como infratores.

Ainda assim, é possível pensar que essa fratura também traria consigo a possibilidade do rompimento, que reconstrói e ressignifica, lançando o olhar para outra direção. Nesse sentido, ao final, Freud afirma que muitos especialistas de outras disciplinas estariam estudando a psicanálise e, então, seria possível esperar uma boa colheita. As transgressões colocadas pelas incursões psicanalíticas, assim, não eram de todo rechaçadas, e começavam a encontrar guarida.

Ainda é possível indagar se de fato bastaria que um psicanalista tivesse conhecimento da área em que faria sua reflexão para que não houvesse críticas contrárias a esse fazer. Ou então, que um especialista de alguma área estudasse a fundo a psicanálise, para que cessassem as oposições. O que, na verdade, parece se colocar como questão é a própria psicanálise aplicada e as tensões que a envolvem.

Ao percorrer esses vários textos, foi possível identificar a potencialidade conferida às aplicações da psicanálise a outras áreas do saber na teoria freudiana. Freud indica que o inconsciente teria de ultrapassar a área na qual foi descoberto. Ele destaca também o posto diferenciado da psicanálise em meio às ciências médicas e aponta para a possibilidade de ela se tornar indispensável às ciências humanas. O alcance frutífero da psicanálise contribuiria para estreitar os laços com os outros ramos do saber.

É possível falar ainda de uma fecunda herança freudiana deixada às futuras gerações de psicanalistas e não psicanalistas. Nas palavras de Freud, haveria material de trabalho para uma geração de pesquisadores e ele seria realizado tão logo as resistências contra a psicanálise fossem superadas em seu campo de origem. A eles, assim, não faltaria trabalho, tampouco resistências. A expansão, transmissão e aproximação da psicanálise com as demais ciências estariam em jogo nesse fazer. 
Por fim, vale destacar algumas considerações feitas por Freud em um dos textos do final de sua obra. Nele, Freud (1933b) busca responder a questão a respeito de a psicanálise poder levar a uma determinada visão de mundo, e, em caso positivo, qual seria ela.

Segundo Freud (1933b, p. 322):

\begin{abstract}
"Visão de mundo" é, receio, um termo especificamente alemão, cuja tradução em outras línguas deve criar dificuldades. Tentarei uma definição para ele, embora ela certamente lhes parecerá canhestra. Entendo que uma visão de mundo é uma construção intelectual que, a partir de uma hipótese geral, soluciona de forma unitária todos os problemas da nossa existência, na qual, portanto, nenhuma questão fica aberta, e tudo que nos concerne tem seu lugar definido. [...] Acreditando numa visão de mundo, podemos nos sentir seguros na vida, saber ao que devemos aspirar e como alocar da maneira mais apropriada os nossos afetos e interesses.
\end{abstract}

Freud (1933b) é, então, contundente quando afirma que se essa é a definição de visão de mundo, seria fácil localizar a psicanálise. Enquanto ciência específica, um ramo da psicologia - uma psicologia da profundeza ou do inconsciente - ela seria totalmente inadequada para criar uma visão de mundo própria, devendo aceitar aquela da ciência. Segundo ele, a visão de mundo científica se distancia notavelmente da definição da psicanálise, já que aceita a explicação única do mundo, mesmo que como um intento permanentemente adiado. De resto, afirma Freud (1933b, p. 323): "caracteriza-se, negativamente, pela limitação ao que é cognoscível no momento e pela nítida rejeição de determinados elementos que lhe são estranhos".

Para Freud (1933b, p. 323):

foi dado ao seu século encontrar a presunçosa objeção de que tal visão de mundo é insatisfatória e mesquinha, de que ignora as exigências do intelecto e as necessidades da psique humana. Para o autor vienense, essa objeção deve ser vigorosamente repudiada. Ela seria insustentável, pois o intelecto e a psique são objetos da investigação científica, exatamente como qualquer coisa não humana. A psicanálise teria, então, o direito de falar em nome da visão de mundo científica nesse ponto, já que não pode ser acusada de haver negligenciado o psíquico no quadro que faz do mundo. Sua contribuição à ciência consistiria exatamente em estender a investigação à esfera psíquica. Sem uma psicologia desse tipo, a ciência ficaria muito incompleta. 
No entanto, conforme Freud (1933b, p. 324):

se a pesquisa das funções intelectuais e emocionais do ser humano (e dos animais) é incluída na ciência, vê-se que nada se modifica em sua atitude geral: não surgem novas fontes de saber ou novos métodos de pesquisa. Também nota-se, sem dificuldade, que as exigências relativas a uma visão de mundo têm apenas uma base afetiva. A ciência toma nota do fato de que a psique humana cria tais exigências e está pronta para examinar suas fontes, mas não tem o menor motivo para reconhecê-las como sendo justificadas. Pelo contrário, ela se vê exortada a distinguir cuidadosamente entre o saber e tudo que é ilusão, resultado dessa exigência afetiva.

O autor diz, em seguida, que a verdade não pode ser tolerante, não permite compromissos e imitações, que a pesquisa tem de considerar todos os âmbitos da atividade humana como seus e deve se tornar implacavelmente crítica, quando um outro poder busca usurpar alguma parte dela. Dos três poderes que poderiam disputar à ciência o território, apenas a religião seria um inimigo sério. A arte seria quase sempre inofensiva e benéfica, não querendo ser outra coisa que não ilusão. Já a filosofia não se opõe à ciência; comporta-se ela mesma como uma ciência, trabalhando em parte com os mesmos métodos, e distanciando-se dela ao se ater à ilusão de produzir um quadro coeso e sem lacunas do universo, que, no entanto, necessariamente se desfaz a cada novo avanço do saber.

Para finalizar, Freud (1933b) afirma que a psicanálise não é capaz de criar uma visão de mundo. Ela não precisaria de uma, na verdade, pois é parte da ciência e pode se filiar à visão de mundo científica, que possui traços essencialmente negativos, como a resignação à verdade e a recusa das ilusões.

Assim, Freud recusa dar o estatuto de visão de mundo à Psicanálise. E, desse modo, fica claro que essa teoria e prática não pretendem, ao se estenderem a outros campos, adquirirem a posição de teoria mestra, aptas a responderem a todas as questões. No entanto, isso não quer dizer que tal uso não possa ocorrer. Nesse sentido, é possível retomar a ideia de que a psicanálise em interface com outros campos coloca em jogo o viés educativo que ela pode adquirir caso seja colocada numa mera aplicação em relação a outros saberes. Considera-se este potencial educativo na medida em que esta aplicação explica determinado fenômeno a partir de seu arcabouço teórico, sabendo de antemão a resposta a ser dada e não fazendo descobrir, princípio fundamental colocado pelo método psicanalítico. 


\section{Lacan e a Psicanálise aplicada}

As considerações de Lacan acerca da psicanálise aplicada, em $A$ juventude de Gide ou a letra e o desejo, e os textos centrais do autor no que se refere à relação da psicanálise com seu exterior, presentes em Outros Escritos - $O$ ato de fundação e Proposição de 9 de outubro de 1967 sobre o psicanalista da Escola serão tratados em detalhes neste capítulo. Lacan apresenta, em seus textos, um posicionamento claro em relação ao fazer psicanalítico voltado para outros campos. De maneira muito particular, ele $o$ articula com a análise didática, ou seja, a formação psicanalítica e, desse modo, também retrata os efeitos da conjuntura do movimento psicanalítico francês.

\subsection{A juventude de Gide ou a letra e o desejo}

A resenha crítica de Lacan acerca do livro de Jean Delay, intitulado $A$ juventude de Gide ou a letra e o desejo, publicado em 1956, mostra-se importante para este trabalho na medida em que contém a principal referência de Lacan a respeito da psicanálise aplicada.

Como aponta Lacan (1998), o livro que Jean Delay consagrou à juventude de André Gide foi publicado em dois volumes e teria alcançado o sucesso. $O$ psicanalista francês destaca que a crítica literária, sem discordâncias importantes, rendeu-lhe todas as homenagens e apreciou a multiplicidade de seus méritos.

Lacan (1998) indica que nem por um instante sequer o escrito de Delay teria corrido o risco de se parecer com o que o mundo analítico denomina de psicanálise aplicada. Delay repeliria de pronto o que essa qualificação absurda traduziria da confusão que reina nessa área. A psicanálise só se aplicaria, segundo Lacan (1998), em sentido próprio, como tratamento e, portanto, a um sujeito que fala e ouve.

Fora desse caso, aponta Lacan (1998), só se poderia tratar de método psicanalítico aquele que procedesse à decifração dos significantes, sem considerar nenhuma forma de existência pressuposta do significado. O que o livro em exame 
mostraria brilhantemente seria que uma investigação, na medida em que observa esse princípio, pela simples honestidade de adequação ao modo como um material literário deve ser lido, encontra na ordenação de sua própria narrativa a estrutura do sujeito que a psicanálise designa.

Ainda a esse respeito, Lacan (1998), na mesma obra, salienta que, sem dúvida, os psicanalistas encontrariam, mais uma vez, a oportunidade de se autorizarem a partir da importância de sua doutrina. Melhor fariam preocupando-se com a constatação de que nenhum livro publicado a título de psicanálise aplicada seria preferível a esse, pela pureza do método e pelo equilíbrio de seus resultados.

Assim, pode-se notar que Lacan considera que a psicanálise aplicada é apenas a face terapêutica da psicanálise. Quanto à área que compreende outras produções, como a de Jean Delay, "só se poderia tratar de método psicanalítico aquele que procedesse à decifração dos significantes, sem considerar nenhuma forma de existência pressuposta do significado" (1998, p.758). Ou seja, o psicanalista faria descobrir e não imputaria um sentido a priori ao material estudado.

Dessa maneira, em $A$ juventude de Gide ou a letra e o desejo haveria um exemplo de como "uma investigação, na medida em que observa esse princípio, pela simples honestidade de adequação ao modo como um material literário deve ser lido, encontraria na ordenação de sua própria narrativa a própria estrutura do sujeito que a psicanálise designa" (Ibidem, p.758).

É importante notar que Lacan quer distanciar esse escrito da denominação de psicanálise aplicada. Esse termo traduziria a "confusão que reina nessa área" (Ibidem, p.758). Supomos que não haveria, por parte de Lacan, uma crítica ao fazer que se dá fora dos consultórios. Ele apenas considera necessário que alguns princípios sejam atendidos para que isso seja feito com qualidade, atitude que ele não encontra nesse tipo de exercício.

\subsection{Ato de Fundação de 1964}

Antes de discorrer a propósito do Ato de Fundação, escrito em junho de 1964, mostra-se relevante situar o leitor acerca dos acontecimentos no movimento psicanalítico francês nessa época. Como outros países, depois da Segunda Guerra Mundial, a França Freudiana entrou na era dos conflitos, das 
crises e das controvérsias. As considerações a seguir baseiam-se no livro História da Psicanálise na França 2 (1925-1985), escrito por Elizabeth Roudinesco em 1988.

Segundo Roudinesco (1988), as posições dos três mestres da segunda geração, analisados por Lowenstein, evidenciam as vertentes presentes na Sociedade Psicanalítica de Paris (SPP) da década de 50. Nesse sentido, Roudinesco (1988, p. 242) aponta que:

Favorável a uma assimilação do ensino freudiano aos ideais da medicina, Nacht preconiza a criação de um instituto hierarquizado, com um curso rígido de formação. Procura introduzir a psicanálise na faculdade, preservando enquanto isso sua autonomia jurídica e moral. Apoia os candidatos médicos e encoraja as pesquisas da psicossomática, mas se recusa a deixar aos "grandes chefões" da psiquiatria a preocupação de gerir os assuntos do movimento. Seu projeto se liga, portanto, a uma ortodoxia clássica. Ele traduz uma defesa "à americana" da "psicanálise dos notáveis" e se baseia numa política autoritária que convém numa transferência à sua pessoa.

Lagache, por sua vez, indica Roudinesco (1988, p. 242):

[...] é o promotor de uma integração democrática da psicanálise à psicologia. Nesse sistema, que visa à implantação do freudismo pela via universitária, o saber psicológico ocupa o mesmo lugar que o ideal médico para Nacht. [...] Como bom moralista [Lagache], prefere, a um projeto autoritário, uma política de tolerância fundamentada numa comunicação entre mestres e alunos. Da mesma forma, sustenta dentro da SPP uma corrente liberal hostil ao autocratismo nachtiano. Esse liberalismo não leva à contestação das regras impostas pela IPA. Visa a adaptá-las à nova situação francesa.

Segundo a autora, o antagonismo entre as duas vertentes decorre da divergência quanto ao modo de institucionalização da psicanálise. Roudinesco (1988, p. 242) destaca que: "Quando muito se trata, nos dois casos, de organizar uma sociedade de massa de acordo com as ordens já existentes e sem levar em conta uma política da psicanálise articulada com uma teoria do inconsciente".

Freud, conta-nos a autora, aborda essa complicada questão quando dissolve, em 1907, o primeiro grupo vienense. Ele funda, então, uma sociedade de psicanálise, e não uma associação de psicanalistas. Em outras palavras, afirma 
Roudinesco (1988, p. 243):

os psicanalistas devem organizar-se em torno de uma "causa comum". O vínculo que os une baseia-se numa ética que despreza as relações imaginárias entre os membros do grupo. A sociedade tem por objetivo defender uma teoria, a do inconsciente, e não é feita para apoiar os terapeutas em suas reivindicações profissionais. Eles se reconhecem entre si por trabalharem por uma "causa", mas a sociedade não tem por função fazer valer um reconhecimento horizontal entre os indivíduos de um clã, com fins de garantir o exercício de seu ego: tal é o projeto de uma política da psicanálise centralizada numa teoria do inconsciente. Essa posição não é falsa em si, mas produziu os efeitos desastrosos de que se tem conhecimento. Além disso, Freud aceita o lugar de pai fundador, mas recusa o de chefe político. Daí sua posição de mestre sem mando, que o conduz a deixar a seus discípulos a tarefa de gerir os assuntos do império.

Roudinesco (1988) aponta, ainda a esse respeito, que a história das sociedades psicanalíticas revela algo que surpreende: quanto mais é favorecida a democracia (respeito à participação individual), mais se tende a impedir a ocorrência do trabalho inconsciente. Isso significa, segundo a autora, que se garante na verdade um exercício do ego em detrimento de um combate teórico que vise ao descentramento da posição subjetiva.

A democracia, portanto, supõe um conceito de liberdade que se mostra contrário ao que sustenta à psicanálise, a saber, que os homens não são senhores de sua própria casa, não tem controle sobre o seu destino. Dessa forma, destaca Roudinesco (1988, p.243): "Caso nos atenhamos a essa teoria, será impossível criar uma associação de psicanalistas respeitadora da "liberdade" do ego, sem com isso liquidar a doutrina que ela supostamente defenderia".

Por outro lado, afirma a autora, no outro extremo, encontra-se o autocratismo, que também se quer evitar. Segundo Roudinesco (1988, p.243):

Com efeito, quanto mais nos dobramos à paixão de uma causa, mais corremos o risco do dogmatismo e menos se favorece a emergência de experiências novas. Opor-se à garantia do ego seria voltar-se, então, para o culto de um mestre ou para o ardor de uma mística, o que levaria a substituir a ilusória liberdade da fala individual pela adesão religiosa à pessoa de um chefe ou de uma causa. Até hoje, segundo a autora, nenhuma sociedade psicanalítica logrou êxito em 
resolver essa contradição insolúvel, mas nenhuma admitiu que a contradição seja insolúvel com respeito à descoberta do inconsciente.

No que se refere à cena francesa, para a psicanalista e historiadora, somente Lacan terá êxito em pôr em prática por dezesseis anos, uma instituição inteiramente democrática, porém centrada em uma relação quase "religiosa" com sua pessoa e sua doutrina. Essa breve experiência evidencia a existência da contradição que a autora descreveu anteriormente. Para ela, Lacan ousou correr o risco da verdadeira democracia e, também, tentou evitar as ilusões egóicas.

Roudinesco (1988, p. 244) destaca os meandros que culminou com esse posicionamento de Lacan:

Tendo iniciado antes da guerra um retorno implícito a Freud, nosso herói [Lacan] toma consciência da necessidade de uma organização da formação didática conforme os princípios da descoberta freudiana. Não recusa nem a via universitária nem a via médica, mas faz com que ambas dependam do primado de uma política da psicanálise. Não hesita em assumir o lugar de legislador e comandante-em-chefe, assim se confrontando com a realidade contraditória da democracia e da autocracia.

Seria uma nova ortodoxia (distinta da de Nacht), indica Roudinesco (1988), que decorre da relação de uma teoria com a didática, que respeita o registro da personalidade ao não se furtar a nenhuma de suas antinomias. Nessa perspectiva, afirma a autora, a análise didática é valorizada em ao invés da análise terapêutica, sem que se coloque o problema da unicidade ou diferença entre elas.

Desse modo, segundo Roudinesco (1988, p.245): "Lacan é o único mestre da segunda geração a dotar o movimento francês de uma política da psicanálise articulada com uma teoria da formação". Contudo, as coisas não seriam tão simples. Para a autora (1988, p. 246): 
Antes da guerra, as coisas se passavam de maneira artesanal. Os pioneiros do movimento visavam tanto a uma carreira quanto a uma aventura. Escolhiam seu analista em função de uma atração pessoal e dentre um número restrito de terapeutas, todos efetivos ou em via de passarem a sê-lo. A diferença entre a terapêutica e a didática não decorria de uma sanção teorizada: todos os "doentes" eram analistas em potencial e todos os analistas eram "ex-doentes".

Entre 1947 e 1960, Lacan forma os mais belos florões da terceira geração analítica francesa, afirma a autora. Alguns permanecerão como seus discípulos, enquanto outros o deixarão com a violência necessária à sua própria trajetória.

Na visão de seus colegas, aponta Roudinesco (1988, p. 255):

Lacan reúne um número excessivo de tratamentos didáticos e transforma seus analisandos em alunos. Teme-se que ele se torne um mestre, sem que se indague as razões que motivam a afluência dos alunos a seu divã. Reduz-se sua posição teórica e clínica a um "poder carismático", julgado nefasto.

Assim, afirma Roudinesco (1988), no embate entre os partidários de Lagache e Nacht, a prática clínica de Lacan, mesmo não sendo base do conflito principal, coloca-se como variável preponderante na distribuição das alianças. A autora, mais adiante no texto, indica que Lacan percebe-se sem saída, já que é atacado pelo grupo de Nacht e rejeitado pelo grupo liberal. É evidente que ele teria preferido a uma aliança com o psicologismo de Lagache, um contrato de confiança com o espírito médico. Lagache sabe disso e, sendo assim, não quer que Lacan participe da fundação da nova sociedade para que ninguém possa creditar que essa sociedade foi obra de Lacan. No entanto, dali por diante, Lacan já não tem escolha e apoia, sem participar dele, o projeto de Lagache.

A primeira cisão do movimento psicanalítico francês, então, concretiza-se. Curiosamente, segundo Roudinesco (1988), os demissionários não se apercebem de que, ao deixarem a SPP, estão pronunciando sua exclusão da IPA. Em sua precipitação, Lagache não pensara nesse problema jurídico da mais alta importância. Assim é criada, em 1953, a Sociedade Francesa de Psicanálise (SFP).

Como aponta Roudinesco (1988), dez anos se passam entre a cisão de 1953 e a grande partida de 1963, que leva à explosão da SFP e à criação, por 
Lacan e seus discípulos, da Escola Freudiana de Paris. Durante esses dez anos, a emergência da terceira geração psicanalítica francesa modifica a feição da comunidade freudiana desse país. E, nesse contexto, nada parece ser mais favorável à expansão da psicanálise do que uma batalha permanente e um desejo insatisfeito de reconhecimento.

Desde a criação da SFP, afirma Roudinesco (1988, p.299):

Lacan instaura sua própria política, recusando-se a se sentir responsável pela demissão coletiva. Para levar vantagem sobre Nacht, de um lado, e combater o psicologismo, do outro, opta por dotar o freudismo de uma teoria do sujeito apoiada na filosofia, sem jamais esquecer o saber médico.

A autora, então, utiliza a parábola da tartaruga e do escorpião como metáfora do dilema em que fica preso um pensador a partir do momento em que é obrigado a se identificar com um poder institucional. Se o escorpião atravessa o rio no dorso de uma tartaruga, corre o risco de picá-la e de morrer com ela. Em contrapartida, se decide construir uma ponte, corre um risco muito mais grave: 0 de transformar-se em tartaruga e passar da posição de "mestre sem mando" para a de chefe de escola.

Segundo Roudinesco (1988, p.316):

Vimos como Freud escapou dessa alternativa, confiando a seus discípulos a gestão do império. Enquanto permanece como escorpião, Lacan continua hegeliano. Sabe que o "ser para a morte" é a imagem última do "ser analista". Mas, se construir uma ponte, sabe também que será obrigado, em prazo maior ou menor, a fundar uma instituição destinada a ser o reflexo de sua própria doutrina. Munido da experiência freudiana, esse grande leitor de Maquiavel compreende muito cedo a incompatibilidade existente entre 0 exercício real de um poder institucional e a posição de mestre pensante. 
Na SFP, conforme Roudinesco (1988, p. 317):

\begin{abstract}
Lacan procura instaurar essa política do inconsciente do qual Freud fora o fundador falho. No entanto, ele não está a salvo dos paradoxos de seu temperamento, tanto assim que não consegue impedir-se de fundir sua pessoa com sua doutrina, demandando a seus alunos que ou o amem ou o sirvam. Entretanto, como não é um ditador nem um paranoico perigoso, conhece perfeitamente os limites dessa espécie de reinado: ele se sabe rei de uma monarquia imaginária, fundamentada na servidão voluntária.
\end{abstract}

Para a autora, por esse motivo, durante dez anos, Lacan espera integrarse ao império. Decidindo abandoná-lo, arriscaria não apenas ter de renunciar a qualquer projeto expansionista, mas, sobretudo, ser obrigado a criar uma escola à sua imagem, na qual se fundiriam seriamente a doutrina e a pessoa do mestre. Para Roudinesco (1988), revela-se evidente que a pertença à IPA pode permitir a Lacan permanecer como pensador e poupá-lo de ter que administrar uma política "a seu nome". Ao contrário, qualquer ruptura definitiva o levaria inevitavelmente a se identificar com um poder político que faria dele não mais um produtor de significantes, mas um chefe de escola.

Mais ou menos conscientemente, segundo Roudinesco (1988, p.317), Lacan:

sabe que essa postura fusionante é insustentável: de fato, mais vale o difícil lugar de animal dinamitador que o lugar confortável de uma tartaruga livre de seus escorpiões. Assim, podemos levantar a hipótese de que a busca lacaniana de uma integração ao império funciona como o sintoma de uma vontade do mestre de não se tornar um chefe de instituição. Segundo essa perspectiva, cabe admitir que Lacan só fundaria sua escola constrangido e forçado, ao se aperceber de que não mais podia escapar às regras nem fazer com que sua posição de mestre fosse aceita pela IPA.

Todavia, afirma Roudinesco (1988), ao mesmo tempo que, perde toda a esperança de pertença ao império, Lacan se arriscará a perder-se numa identificação soberana com seu próprio nome, ou, mais precisamente, com o nome de um chefe. Durante os dez anos da existência da SFP, Lacan tem tempo para reinar como um príncipe sem ter ainda a responsabilidade de um príncipe. 
Não seria por acaso, na visão de Roudinesco (1988, p. 317), que Lacan: "elabora a parte essencial de sua obra enquanto se acha, como seus colegas, na posição de um exilado em busca de reconhecimento. Em dez anos, funda o que hoje se denomina de lacanismo e que, mais simplesmente, deveria chamarse freudismo".

Vale lembrar com Roudinesco (1988) que desde a cisão, Lacan não modificou nada em sua prática clínica. Acentuou o princípio do "bangue-bangue da interpretação verdadeira" e tendeu a reduzir ainda mais a duração das sessões. É importante acrescentar também que vai se impondo a primeira fase de um processo que tende, simplesmente, a não mais separar a visão terapêutica da visão didática, e a considerar a formação segundo um novo ponto de vista. Este processo se tornará comum na Escola Freudiana de Paris.

A autora salienta que a IPA teme, principalmente, aquilo a que denomina, como o "carisma" dos chefes, preferindo a ele o tecnicismo dos barões. Compreende-se, então, segundo a psicanalista e historiadora, como nasce essa representação do poder no interior do movimento psicanalítico. Os herdeiros de Freud se proibiram de imitar a prática do pai fundador, não apenas por terem-na considerado pouco adequada à expansão moderna da psicanálise normatizada, mas porque, por definição, um fundador é único e não deve ser imitado.

Roudinesco (1988) tem a hipótese de que o repúdio da noção de mestre pensante e seu encobrimento pela de um "carisma" julgado nefasto permitem à IPA admitir em seu seio todas as divergências doutrinais, sob a condição de que sejam aceitas as normas técnicas de formação. Dessa forma, o respeito pelas doutrinas divergentes, segundo a autora, passa pela fidelidade a um sistema comum.

Por conseguinte, qualquer doutrina que conteste o princípio aceito da formação é considerada suspeita. Assim, para Roudinesco (1988) assiste-se a esse paradoxo inaudito: quanto mais inovadora é uma doutrina, mais se deve proibi-la de produzir uma nova teoria da formação. Entretanto, como é evidente que toda doutrina inovadora afeta a formação, isso quer dizer que, num prazo maior ou menor, ela não será admitida no império. Por essa razão, os conflitos internos ao movimento analítico sempre têm por pivô manifesto os problemas da didática e, por núcleo latente, as questões da doutrina. 
A segunda cisão do movimento psicanalítico francês ocorreu durante o inverno de 1963. Foi vivida como um desastre por todos os membros da SFP, tanto pelos alunos quanto pelos negociadores: Leclaire, Lacan, Granoff, Perrier, e Pierre Turquet pela Grã-Bretanha. Em 1964, a SFP foi dissolvida e Lacan fundou a École Freudienne de Paris (EFP), enquanto a maioria de seus melhores alunos se posicionou ao lado de Lagache, na Associação Psicanalítica da França (APF), reconhecida pela IPA.

É nesse contexto que se insere o "Ato de Fundação", a saber, na origem da EFP. Já nos primeiros parágrafos, Lacan (2003, p. 229) revela que:

\begin{abstract}
Esse título [Ato de Fundação] em minha intenção representa o organismo em que deve realizar-se um trabalho - que, no campo aberto por Freud, tem por objetivo buscar restaurar a sega cortante de sua verdade; reconduzir a práxis original que ele instituiu sob o nome de psicanálise ao dever que the compete em nosso mundo; que, por uma crítica assídua, denuncie os desvios e concessões que amortecem seu progresso, degradando seu emprego.
\end{abstract}

Esse objetivo de trabalho seria indissociável de uma formação a ser dispensada nesse movimento de reconquista.

Lacan (2003) propõe então uma nova forma de funcionamento institucional, avesso ao dogmatismo. Ele destaca que aqueles que fizerem parte daquela Escola terão que se responsabilizar por cumprir uma tarefa de controle interno e externo. E em troca, será garantido que tudo o que produzirem de válido seja disseminado, e no lugar que for adequado para tanto.

Nesse ponto, vale lembrar com Kupermann (1996) o que afirma Lacan em La Chose Freudienne ou Sens du Retour à Freud en Psychanalyse. Nesse texto, o psicanalista francês conta ter recebido da "própria boca" de Jung a informação de que Freud teria Ihe dito, ao avistar o porto de Nova York, na célebre viagem de 1909 à América: "Eles não sabem que Ihes estamos trazendo a peste". A imagem da psicanálise como a peste é usada entre nós (e, claro, na França), a partir desse relato, como uma verdade freudiana incontestável, inclusive pelos autores mais respeitáveis.

Segundo Kupermann (1996), Lacan cria uma ficção mais verídica que a própria história, para apontar três "verdades" referentes ao campo psicanalítico, 
fundamentais para o movimento de retorno a Freud: 1) que Freud se iludiu quanto aos efeitos que a psicanálise produziria na América; 2) que havia outra peste a ser combatida, a "doença" americana chamada psicologia do ego, que voltava do outro lado do Atlântico, agora de "primeira classe"; e 3) que era preciso restituir o sentido da mensagem freudiana original.

Assim, afirma Kupermann (1996), ao promover o movimento de retorno de Freud apoiado na imagem virulenta e transgressiva da peste, Lacan buscava resgatar a potência original de uma psicanálise transformadora e underground, cuja ênfase residia no primado do inconsciente e na Spaltung (clivagem) originária do sujeito, denunciando, ao mesmo tempo, os desvios e as capturas sofridas pela mensagem freudiana. Segundo Kupermann (1996) era preciso retornar ao ponto de partida, para dali partir novamente. E não seria por acaso que essa conferência foi pronunciada em Viena. Ao criar a parábola, Lacan apontaria, de fato, os efeitos da captura da psicanálise por uma lógica da ilusão. Nesse caso, a ilusão adaptativa, a ilusão do conforto, a ilusão egoica.

A pertinência da imagem produzida por Lacan não está em questão, aponta Kupermann (1996). Interessa, no entanto, ressaltar, segundo o autor, que, já em suas bases, o projeto lacaniano de retorno a Freud traz em si outra dimensão de retorno, referente a um ato de fundação e a um mestre fundador, no qual aquele que "retorna" passa a ocupar seu lugar, dando início a uma nova partida. Para Kupermann (1996), o risco que daí advém é o de se criar uma homogeneidade entre a palavra do fundador e a daquele que a ele retorna, produzindo uma nova fundação que vem, de fato, tomar o lugar da original, que passará por sua vez para o registro de um tempo perdido e irrecuperável. Neste caso, para o autor, o risco seria fazer da palavra de Lacan a palavra de Freud, anulando toda e qualquer diferença entre os dois corpus teóricos. Se a metáfora da peste por si só não implica maiores comprometimentos no nível conceitual, veremos adiante algumas consequências mais pragmáticas do retorno a Freud.

Com a fundação da Escola Freudiana de Paris, o retorno a Freud deixa de ser apenas um retorno ao sentido de Freud, como queria Lacan em 1955, passando a abranger de fato outras dimensões, afirma Kupermann (1996). Segundo ele, Micheline e Eugène Enriquez, em Le Psichanalyste et Son Instituition, consideram que a Escola é estruturada em vários aspectos, sob o 
signo do retorno: retorno a Freud, no sentido de retomar as exigências teóricas rigorosas, promovendo um trabalho de elaboração doutrinária; retorno aos primeiros momentos do movimento psicanalítico, no sentido de resgatar a dimensão da causa psicanalítica à qual os membros poderiam se dedicar e contribuir ativamente, em oposição ao caráter passivo que passou a caracterizar a relação dos psicanalistas com as suas sociedades desde a padronização da formação; e retorno, talvez, também a uma dimensão mais mítica: o ato de fundação da Escola iniciado efetivamente por estes termos: "Fundo tão sozinho como sempre estive na minha relação com a causa psicanalítica [...]", reenviando diretamente à posição inaugural de Freud.

Assim, destaca Kupermann (1996), pelo ato de fundação da Escola, Lacan efetua um corte transferencial inédito na história da psicanálise, reivindicando o estatuto mítico de mestre fundador que era, até então, exclusivo de Freud. Logo as consequências transferenciais desse retorno mítico ao ato de fundação se farão enxergar.

Uma última consideração quanto ao estatuto do "tão sozinho como sempre estive na minha relação com a causa psicanalítica". Em outra leitura, aponta Kupermann (1996), essa "solidão" seria atribuída ao ato analítico - o analista está sempre só frente ao seu ato. Ora, mesmo que isto se aplique (e se aplica), indica o autor, ao ato analítico no decorrer de uma análise, trata-se de "psicanálise em intensão". Em seguida, ele interroga se seria legítimo estabelecer uma analogia direta entre os conceitos de "psicanálise em intensão" para a "psicanálise em extensão".

Ainda para Kupermann (1996), fundar uma Escola diz respeito ao encontro entre "intensão" e "extensão"; o ato ganha, assim, uma complexidade que transcende o espaço entre a poltrona e o divã. Afinal, segundo ele, se todo analista, em seu ato, está só na sua relação com a causa psicanalítica, nem todo analista funda uma Escola. Insistir nessa leitura levaria à conclusão de que talvez alguns analistas estejam mais sós do que outros, ou de que outros (a maioria esmagadora) estejam menos sós do que deveriam.

Segundo Lacan (2003), para a execução do trabalho na Escola será adotado o princípio de uma elaboração apoiada num pequeno grupo (no mínimo três pessoas, no máximo cinco); ao todo, serão três grupos. Após certo tempo 
de funcionamento, os componentes de um grupo verão ser-lhes proposta a permuta para outro. Lacan lembra ainda que o cargo de direção não constituirá uma chefia cujo serviço prestado seja capitalizado para o acesso a um grau superior, e isso não implicaria, de modo algum, uma hierarquia de cima para baixo, mas uma organização circular cujo funcionamento, fácil de programar, se firmará na experiência.

Lacan (2003) constituirá três grupos ou, como ele nomeia, três seções. A seção de psicanálise pura, ou seja, práxis e doutrina da psicanálise propriamente dita, que não seria nada além da psicanálise didática. Nela haveria ainda três subseções: doutrina da psicanálise pura, crítica interna de sua práxis como formação, e supervisão dos psicanalistas em formação. Em seguida, a seção de psicanálise aplicada, o que significa de terapêutica e clínica médica. Também esta com três subdivisões: doutrina do tratamento e de suas variações, casuística, informação psiquiátrica e prospecção médica. E, por fim, a seção de recenseamento do campo freudiano. Ela asseguraria, para começar, o levantamento e a censura crítica de tudo o que é oferecido nesse campo, pelas publicações que se pretendem autorizadas por ele. Também com três subseções: comentário contínuo do movimento psicanalítico; articulação com as ciências afins; e ética da psicanálise, que é a práxis de sua teoria.

Interessa enfatizar que, então, para Lacan, a psicanálise aplicada referese à prática clínica, assim como foi evidenciado na resenha acerca do livro de Jean Delay. Por outro lado, a articulação com as ciências afins situa-se no âmbito do recenseamento do campo freudiano. A terceira seção:

convocará, tanto para instruir nossa experiência quanto para comunicá-la, aquilo que, do estruturalismo instaurado em certas ciências, puder esclarecer aquele cuja função demonstrei na nossa e, no sentido inverso, aquilo que, de nossa subjetivação, essas mesmas ciências puderem receber de inspiração complementar (LACAN, 2003, p. 238).

Como aponta Costardi (2011), vemos que Lacan estabelece uma via de mão dupla entre a psicanálise e as chamadas ciências afins. Nesse contato, a 
psicanálise tem a possibilidade de instruir sua própria experiência, bem como comunicá-la. As demais ciências, por sua vez, receberão uma inspiração da psicanálise. A noção de inspiração retira o ideal da psicanálise de ser uma teoria-mestra em relação às outras áreas, o que não era claro em Freud, segundo a autora.

Para Costardi (2011), talvez derive da posição freudiana certa discussão sobre a ideia da aplicação. Nessa discussão "temos que aplicar" diria respeito a uma teoria "acabada" que será colocada sobre um objeto exterior, explicando-o, tratando-o, recobrindo-o. Ficaria de lado a noção de que, em psicanálise, todo objeto, se apreendido em sua singularidade, está além da teoria, a interroga e a desconfirma.

É interessante frisar que buscamos com esta parte do trabalho delinear em que medida a relação de Lacan com os outros campos do saber insere-se num âmbito maior, a saber, seu posicionamento em relação ao movimento psicanalítico francês, que culminou na criação da Escola Freudiana de Paris. Assim, não se trata apenas de mostrar como o psicanalista francês coloca-se diante desse tema, mas o que estava em jogo naquele momento específico, e como Lacan posicionou-se.

\subsection{Proposição de 9 de outubro de 1967}

Na Proposição de 9 de outubro de 1967 sobre o psicanalista da Escola, por sua vez, Lacan também faz apontamentos no que se refere às incursões da psicanálise em relação a outros campos, mas sob outra chave, não mais a partir de uma das seções da EFP.

Até chegar a este ponto específico da discussão, Lacan (2003, p.250), dentre outras considerações, indica que os analistas: "Encontram-se agrupados na EFP por não terem querido através de uma votação aceitar o que esse voto pautaria: a pura e simples sobrevivência de um ensino, o de Lacan". Para o psicanalista francês, era isso que estava em jogo. A seu ver, o impedimento pela IPA de que ele formasse analistas didatas à época da SFP nenhuma relação tinha com a formação de analistas, embora muitos afirmassem que essa era a questão central. 
Lacan (2003, p. 250) observa, em seguida, que ofereceu a fundação da Escola:

[...] a um grupo para o qual meu ensino era tão precioso ou tão essencial que cada um, deliberando, marcou preferir a vantagem oferecida [...], foi a esse grupo em dificuldade de encontrar uma saída que ofereci a fundação da Escola.

Lacan (2003), então, conclui que não haveria nenhum ensino semelhante ao dele, pois nenhum diria o que é a psicanálise. Em outros espaços, e de forma expressa, ela seria apenas conforme. Segundo o autor francês (p.250): "Existe uma solidariedade entre a pane ou os desvios mostrados pela psicanálise e a hierarquia que nela impera - e que designa, com benevolência, como hão de reconhecer, como a cooptação de doutos".

A razão disso, afirma Lacan (2003, p.250):

é que tal cooptação promove o retorno a um status de imponência, conjugando a pregnância narcísica com a astúcia competitiva. Retorno que reestabelece reforços do relapso, o que a psicanálise didática tem por fim eliminar. É esse o efeito que lança sua sombra sobre a prática da psicanálise - cujo término, objeto e até objetivo revelar-se-iam inarticuláveis, após pelo menos meio século de experiência ininterrupta.

Para o autor, a via para contornar tal situação seria a constatação da falha que ele registrou, longe de pensar em desconsiderá-la, mas para colher nessa falha a articulação que falta. Segundo Lacan (2003, p. 251):

Ela só faz confirmar o que se encontra por toda parte e é sabido desde sempre: não basta a evidência de um dever para que ele seja cumprido. É por intermédio de sua hiância que ele pode ser posto em ação, e o é toda vez que se encontra o meio de utilizá-la.

Para explicitar melhor o que quis dizer, o psicanalista francês aponta que fará uma introdução. Para tanto, indica que se apoiará nos dois momentos da junção do que ele chamará, respectivamente, de: 
Psicanálise em extensão, ou seja, tudo o que resume a função de nossa Escola como presentificadora da psicanálise no mundo, e psicanálise em intensão, ou seja, a didática, como não fazendo mais do que preparar operadores para ela (LACAN, 2003, p.251)

Nessa parte do texto, Lacan irá discorrer, em detalhes, sobre a articulação entre psicanálise em intensão e extensão, na tentativa de iluminar a questão levantada, anteriormente, acerca da falha da Instituição Psicanalítica em garantir o seu dever, a saber, a transmissão da psicanálise. Apenas mais à frente ele fará considerações específicas em relação à psicanálise em extensão.

Como indica Kupermann (1996), foi no sentido de explicitar as funções que deveriam ser desempenhadas pela Escola Freudiana de Paris e sua dimensão ética que Lacan introduziu a distinção entre as noções de psicanálise em extensão tornar a psicanálise presente no mundo - e psicanálise em intensão - a didática, ou seja, formar analistas. Assim, a psicanálise em extensão e psicanálise em intensão, segundo o autor, aparecem irredutivelmente articuladas em torno de uma concepção da ética da psicanálise, sendo esta, para Lacan, a práxis de sua teoria.

Para Kupermann (1996), desde os anos 1950 havia uma crise manifesta relativa à formação psicanalítica, na qual Lacan interferiu agudamente, resultando em seu impeachment enquanto analista didata e no rompimento de 1964. Porém, desde então, nenhuma alternativa real teria sido formulada, e o objetivo de Lacan com a fundação da Escola, culminando na Proposição de 9 de outubro de 1967, era justamente propor essa alternativa.

Na IPA, afirma Kupermann (1996), a formação havia deixado de ser questão desde que passou a ser regulada por princípios exteriores à própria análise, na forma de cumprimento de normas institucionais que caracterizavam as análises didáticas. A contribuição radical de Lacan, para o autor, teria sido fazer da formação psicanalítica novamente uma questão, buscando formular a análise didática a partir de uma lógica interna à psicanálise. A didática passaria a ganhar assim uma autenticação de fato, e não mais de direito, isto é, ao invés de uma análise ser definida a priori como didática por ser conduzida por um didata, segundo determinadas normas, ela seria considerada didática a partir de seu resultado.

Kupermann (1996) destaca que buscando um princípio lógico que pudesse dar contornos para a questão capital da análise didática, Lacan acaba por criar uma 
concepção de final de análise estreitamente articulada à questão da instituição psicanalítica, pois está centrada na passagem do analisante a analista, ou seja, no núcleo daquilo a que a Escola deve responder: a transmissão da psicanálise.

O desejo do analista - essência da transmissão da psicanálise para Lacan vai se colocar, portanto, segundo Kupermann (1996), no ponto de intersecção entre a psicanálise em intensão e a psicanálise em extensão, já que se refere tanto ao destino e ao testemunho de uma análise quanto à transmissão da experiência psicanalítica na cultura, e sua elucidação seria tarefa tanto do psicanalista quanto da Escola.

À Escola caberia, para o autor, escapar aos efeitos de grupo enquanto lugar de comunhão entre psicanalistas. A estes, caberia responder à indagação sobre o desejo do analista. Esses dois registros estão interligados no ponto de junção entre psicanálise em intensão e extensão, remetendo à transmissão da psicanálise, ao passe, e enfim, a certo tipo de questionamento da transferência.

Retornemos ao texto de Lacan (2003): o psicanalista francês, inicialmente, faz uma diferenciação importante. Num primeiro momento, ele discorre a respeito da psicanálise didática. Sua razão de ser seria constituir a psicanálise como uma experiência original, levá-la ao ponto em que nela figurasse a finitude, para permitir o a posteriori, efeito de tempo que, em seu ponto de vista, Ihe seria radical. Ele, então, pontua que essa experiência seria fundamental para diferenciá-la da terapêutica, que não distorceria a psicanálise somente por relaxar seu rigor. Ele acrescenta que, com efeito, não haveria definição possível da terapêutica senão a de restabelecimento de um estado primário.

Depois dessa consideração, Lacan (2003, p.252) define quais seriam os dois pontos de junção indicados anteriormente, em que teriam que funcionar os órgãos de garantia: "são o começo e o fim da psicanálise, como no xadrez". Quanto ao começo, ele destaca a transferência; já o término seria, com efeito, a passagem do psicanalisante a psicanalista.

Ao final de seu texto, o autor trata, então, da psicanálise em extensão de forma detida. Lacan (2003, p.261) afirma que: "é no próprio horizonte da psicanálise em extensão que se ataria o círculo interior que traçamos como hiância da psicanálise em intensão". Esse horizonte ele centra em três pontos: no 
simbólico, no imaginário e no real.

Quanto ao primeiro, ter-se-ia o mito edipiano. Lacan (2003, p.262) destaca: "retire-se o Édipo, e a psicanálise em extensão, diria eu, tornar-se inteiramente da alçada do delírio do presidente Schreber". Ele acrescenta, em seguida, que (p.262): "Há outros aspectos desse ponto que se referem nossas relações com o exterior, ou mais exatamente, a extraterritorialidade".

O segundo ponto constitui-se, segundo Lacan (2003, p.262): "pelo tipo existente, de facticidade dessa vez evidente, de unidade: a sociedade de psicanálise, como encabeçada por um executivo de escala internacional". Ele refere-se às identificações imaginárias presentes nesse tipo de configuração relacional, semelhante, no que diz respeito à estrutura de grupo, aos modelos apresentados por Freud: a Igreja e o Exército. Segundo Lacan (2003, p.262): "o efeito induzido pela estrutura assim privilegiada também se esclarece ao se lhe acrescentar a função, na Igreja e no Exército, do sujeito saber".

Lacan (2003, p.262) ainda destaca que:

A nos atermos ao modelo freudiano, aparece de maneira flagrante o favorecimento que dele recebem as identificações imaginárias, e ao mesmo tempo, a razão que submete a psicanálise em intensão a limitar a elas sua consideração, ou até seu alcance.

Por fim, a terceira facticidade, no real, é o que, para Lacan (2003, p. 263): "torna dizível o termo campo de concentração, sobre o qual nos parece que os pensadores, vagando do humanismo ao terror, não se concentraram o bastante". A seu ver (Ibidem, p. 263):"o futuro de mercados comuns encontrará seu equilíbrio numa ampliação cada vez mais dura dos processos de segregação".

Assim, Lacan confere um estatuto muito particular à psicanálise em extensão na medida em que a articula à psicanálise em intensão $E$, nesse sentido, podemos afirmar que sua conceitualização difere da de Freud. Lacan, também, está às voltas com a questão da transmissão da psicanálise, porém está a par das dificuldades que ela coloca na sua relação com a Instituição Psicanalítica. E, nesse sentido, o autor propõe algo novo com a Escola Francesa de Psicanálise. O que nos leva a afirmar que Lacan avançou na questão que envolve a Psicanálise em sua interface com outros campos de uma maneira muito singular, e ofereceu um arcabouço teórico consistente para essa reflexão. 


\section{Em Busca de sentidos}

Após as importantes considerações de Freud e Lacan, neste capítulo do trabalho será possível dar início à reflexão sobre os apontamentos de diversos autores contemporâneos a propósito do assunto. Apresentamos, também, quais são as construções e posicionamentos implicados na variedade de nomes dados ao fazer psicanalítico voltado a outros campos do saber.

O primeiro dos artigos a ser discutido é o de Michel Plon (1999): A face oculta da psicanálise leiga. O psicanalista francês está entre aqueles que utilizam o termo psicanálise aplicada sem aspas. Ela não está sob ressalva, mas o autor não evita a discussão e os embates que a envolvem. E fornece uma hipótese interessante sobre o que estaria latente nas críticas à psicanálise aplicada. Vejamos como ele constrói o caminho até ela.

Num primeiro momento, o autor francês anuncia aquilo que se pode notar na primeira parte deste trabalho: indica o que considera ter sido um "lembrete" freudiano, passagem do posfácio de seu texto $A$ questão da Análise Leiga (1927/1996): "Na realidade a linha de demarcação se situa entre a psicanálise científica e sua aplicação nos campos médicos e não médico". A psicanálise aplicada seria, então, de fato, uma das modalidades da aplicação da psicanálise científica, uma das faces do conjunto que pode ser classificado de psicanálise leiga, enquanto a outra face seria a prática psicanalítica com finalidade terapêutica.

Plon (1999) considera esse trecho um lembrete, tendo em vista que se insere na continuidade de uma longa série de declarações e de tomadas de posição que, longe de limitarem-se ao registro único da proclamação, deram lugar às realizações que seriam verdadeiras joias da obra freudiana, o que também já pudemos mostrar anteriormente.

Depois de trazer trechos da correspondência de Freud com diversos de seus interlocutores, pontuando as nuances presentes quando se fala da relação de Freud com as produções da psicanálise aplicada, o psicanalista francês conclui que objetivos, estratégias e meios editoriais, receios e reticências, seriam os dizeres de Freud sobre a questão; dizeres dos quais Plon (1999) só teria dado amostras fragmentadas. 
Antes de evocar o que Freud fez, ou, mais exatamente, de que forma o que ele fez corresponde, desmente ou suaviza o que ele disse, Plon (1999) considera impor-se um exame do que lhe parecem ser as duas críticas mais sérias formuladas a propósito da psicanálise aplicada, como para orientar as leituras que possam ser feitas das realizações freudianas nessa matéria.

A primeira das críticas, segundo o autor, foi formulada por Yosef Hayim Yerushalmi ${ }^{11}$. Ele a faz a partir da leitura de Moisés e Monoteísmo. Para o historiador, nesse texto Freud se entregaria a um exercício de psicanálise aplicada, já que ele se autoriza claramente a interpretar a religião e a cultura judaicas em termos psicanalíticos a partir de uma analogia feita entre os processos psíquicos individuais e os processos coletivos, chegando mesmo - e aí estaria, segundo Plon, a maior crítica que Yerushalmi faz a Freud - a postular a existência de uma identidade entre o individual e o coletivo.

De acordo com Plon (1999), essa seria uma extensão ilícita da interpretação analítica aplicada a um material discursivo que não provém diretamente do inconsciente, pois não resulta do emprego da "regra fundamental", que implica a produção de um material essencialmente constituído de "associações livres". Recurso insistente, até mesmo exclusivo, à figura da analogia e até a da identidade entre dimensões heterogêneas, o individual e o coletivo, para fundamentar tal utilização extensiva da interpretação. Yerushalmi ainda reputa a Freud a responsabilidade por ter sido o primeiro a abrir essa "Caixa de Pandora" que constitui a psicanálise aplicada.

A partir dessa afirmação, Plon (1999) faz uma indagação que será o "giro" da sua argumentação:

Seria então a psicanálise aplicada, em relação à psicanálise, a tal urna cuja abertura desvendaria seu conteúdo, as piores abominações, mas que têm de ser encaradas seriamente para que seja autorizada a descoberta do fundo da urna, que é onde jaz a esperança? (p.99).

O autor, então, apresenta a segunda das críticas, essa feita por Jacques

\footnotetext{
11 Yosef Hayim Yerushalmi é professor de História, Cultura e Sociedade Judaicas, bem como diretor do Centro de Estudos Judaicos e de Israel, da Universidade Colúmbia. Ele escreveu o livro O Moisés de Freud: judaísmo terminável e interminável, 1992.
} 
Lacan. Segundo ele, o distanciamento permitiria julgar que a crítica enunciada por Lacan se encontraria indubitavelmente na origem da atitude dominante nos psicanalistas de língua francesa no que diz respeito à psicanálise aplicada, a saber, um repúdio mesclado de desprezo, voltado mais para a maneira de chamar que para o procedimento em si, correndo o risco de cair, às vezes, na armadilha do nominalismo.

Para esclarecer melhor essa ambiguidade, Plon (1999) considera ser necessário voltar à declaração de Lacan, assim como ao contexto em que foi proferida. O ano é 1958, por ocasião de um artigo que tratava daquilo que se deveria chamar, ainda que Lacan recuse o termo por cortesia e também porque, no gênero, não era dos piores, uma psicobiografia de André Gide, feita por Jean Delay, que Lacan reconhece, fingindo ratificar aí o julgamento de Delay de que esta "qualificação absurda" de psicanálise aplicada "traduz a confusão que reina nesse lugar".

Da Caixa de Pandora à "confusão" ou vice-versa, poder-se-ia pensar que daria no mesmo, afirma Plon (1999). No entanto, esse julgamento seria precipitado, pois para Lacan, a qualificação, ou seja, a denominação de psicanálise aplicada é que seria a responsável pela confusão.

Para Plon (1999), a sequência de suas palavras confirma o que foi dito, e enuncia que "a psicanálise só se aplica verdadeiramente como tratamento, logo a um sujeito que fala". Rejeição da nomeação e do que ela engloba, quer dizer, uma psicanálise que se aplicaria sem outro desvio, em sentido figurado, o do registro do imaginário e da analogia, a uma produção escrita, por mais elaborada que seja, e que como tal nada teria a ver com a palavra do analisando e não engendraria nenhum efeito, nenhum eco ou remanejamento psíquico por parte do sujeito da enunciação e daquilo que especifica, seu desejo inconsciente.

A partir dessas considerações, Plon (1999) indica que se poderia crer resolvida a ambiguidade apontada anteriormente, e que Lacan coloca outra abordagem, ao lado da psicanálise aplicada assim definida, representada por uma produção psicanalítica francesa vastamente dominada por exercícios psicobiográficos ou patográficos que mostravam mais uma péssima psicologia do que a psicanálise e da qual a crítica literária francesa só consegue se livrar com o advento dos trabalhos de Roland Barthes, marcados pela produção lacaniana. 
Lacan efetuou, no ponto de vista de Plon (1999), uma nova divisão que pretendia depurar um campo no qual de fato instalara-se a maior confusão. Só mais tarde, em 1965, na Ata de Fundação da Escola Freudiana de Paris, Lacan anunciaria mais explicitamente essa divisão, mas sem resolver completamente a ambiguidade nominalista: "A sessão da psicanálise pura, ou seja, a prática e doutrina da psicanálise propriamente dita e que nada mais é que - o que será estabelecido em seu lugar - que a psicanálise didática", a "Sessão de psicanálise aplicada, ou seja, a terapêutica ou clínica" e, por fim, a "Sessão de recenseamento do campo freudiano" em que inscrevia a questão da "articulação com as ciências afins".

Para Plon (1999), após um percurso de quase vinte anos, Lacan teria reencontrado o espírito, ou talvez a letra da partilha freudiana, percurso este marcado por um combate sem trégua contra as diversas formas de retorno ao "psicológico" na psicanálise, quer seja sob a forma de subordinação ao significado, ou sob a forma de uma reificação do "eu forte".

Para deixar claro, afirma Plon (1999), a relação com as "ciências afins", definida como "aquilo que do estruturalismo instaurado em certas ciências pode lançar uma luz sobre o que demonstrei ser a função da nossa - em sentido contrário, àquilo que da nossa subjetivação, essas mesmas ciências podem receber de inspiração complementar", não estaria tão distante quanto poderia parecer da exigência freudiana de reciprocidade no rigor e no saber entre os psicanalistas e os praticantes das disciplinas conexas.

Nesse ponto, Plon (1999) retorna à pergunta colocada há pouco em que se podia antecipar o ponto nodal da sua análise. Para ele, existiriam mais elementos nesta aproximação de Lacan em relação a Freud. E estar-se-ia no direito de perguntar se a indagação de Lacan subjacente a essa partilha não se juntaria com a leitura final que Yerushalmi faz do Moisés de Freud.

Indo além das críticas, Yerushalmi teria, ainda segundo Plon (1999), chegado de fato a identificar como sendo a maior preocupação de Freud naquele livro a questão da transmissão em psicanálise. Plon, então, enfatiza que seria essa mesma questão da transmissão da psicanálise que assombraria a segunda parte da obra e da vida de Lacan e lança a hipótese de que: 
A psicanálise aplicada, livre das impurezas, rearrumada como zona de relação com as ciências afins, não seria o vetor de transmissão daquilo que escapa tanto à didática quanto ao tratamento analítico propriamente dito? Seria esta a esperança guardada no fundo da caixa de Pandora? (Ibidem, p.101).

Para encontrar elementos que respondam a essa questão, Plon (1999) opta por fazer um "retorno a Freud". Ele irá privilegiar o que se relaciona com as críticas feitas por Yerushalmi e Lacan. Segundo o autor, não se pode negar que, a despeito das reprimendas que Freud dirige a um ou outro do seu círculo mais próximo, ele próprio se permitiria interpretações que nada mais seriam do que selvagens. Plon (1999) cita o exemplo da Gradiva (citado por Lacan) e o erro de interpretação que Freud cometeu no texto Uma Lembrança de Leonardo da Vinci; e destaca que já foi possível mostrar sem grande dificuldade que esse tipo de erro, por mais atraente que pareça aos olhos deste ou daquele crítico especializado na matéria em questão, não modifica a dimensão teórica do trabalho de Freud, que não se limitou à ocorrência de uma simples aplicação.

Eis então que o autor faz sua consideração central depois da sequência de análises:

Na verdade, o perigo da deriva interpretativa à qual, além de Freud,
numerosos psicanalistas se entregaram, e o perigo da extensão
aleatória do raciocínio analógico tornaram-se emblemas negativos da
psicanálise aplicada - até o ponto de se ver, efeito da armadilha
nominalista, esta maneira de nomear e o campo de pesquisa que
designa, reduzidos à caricatura em cima desses dois pontos fracos -
porque são mais facilmente encontráveis aí que no terreno da
"psicanálise pura" ou da "psicanálise científica" (PLON, 1999, p.102).

A origem da deriva interpretativa e da extensão abusiva do pensamento analógico não se encontraria de fato, segundo Plon (1999), no campo dos estudos de psicanálise aplicada, porém em outra parte, no dualismo de pensamento quase original e persistente que estruturaria, a seu ver, o conjunto da obra freudiana.

Para ele, seria mais fecundo considerar esse dualismo freudiano como uma manifestação da fragilidade epistemológica da psicanálise - fragilidade que parece insuportável aos representantes do pensamento positivista, a ponto de renovarem seus ataques periodicamente sem a percepção de que estes ataques passam ao largo da especificidade da psicanálise - na medida em que ela não se reduz nem a 
uma ciência natural, o que Freud desejava intermitentemente, nem a uma ciência do espírito, o que Freud recusou de maneira constante.

O dualismo apareceria, para Plon (Ibidem), em mais de uma passagem da obra de Freud. Dualismo entre a teoria do trauma, que atribui a um acontecimento real a origem da neurose, e a teoria do fantasma, cuja concepção historiográfica apressada e rudimentar tende a dizer que substitui definitivamente a primeira em 1897, quando o próprio Freud, em duas de suas obras posteriores, não cessa de levar em conta os dois registros. Ficaria claro que neste ponto as duas "facções" não podem se resolver a admitir que a manutenção por Freud desse duplo registro é testemunho de sua permanente consciência do estatuto incomparável da psicanálise, da fragilidade quanto ao seu futuro do caráter "impossível" de seu exercício acabado.

Para Plon (1999), seria esse mesmo dualismo presente na volta que Freud faz ao simbolismo no sonho, particularmente, em $A$ Interpretação dos Sonhos em que, depois de uma crítica radical destinada a sublinhar a importância e o caráter inteiramente inovador de seu método de interpretação baseado nas associações livres que o sonhador faz a partir do relato-conteúdo manifesto de seu sonho, vamos vê-lo multiplicar, edição após edição, o lugar destinado a esse mesmo simbolismo que termina por ocupar uma posição de destaque no livro.

Segundo Plon (1999), Freud tinha certamente o direito, senão de cometer erros, pelo menos de permanecer ligado a esse dualismo, fossem quais fossem as consequências. Não era preciso jogar todo o peso dessas duas fraquezas, a deriva interpretativa e a generalização analógica, unicamente nas costas da psicanálise aplicada.

De fato, para o autor, Freud não se preocupava com tais críticas: perfeitamente consciente das fraquezas desses pontos do método, ele visava outra coisa cada vez que se autorizava a fazer incursões por domínios externos à psicanálise. Ele tinha por objetivo simplesmente desenvolver pontos em sua teoria que estavam obscuros até então, servindo-se dessas ocasiões que materializavam os personagens ou as obras de arte.

Plon (1999) finaliza salientando que Freud indicara que, além de uma aplicação no sentido de uma colagem ou de um revestimento de uma teoria já 
constituída aplicada a um material bruto, a possibilidade de isolar os elementos de subjetividade empregados nas práticas sociais pode, ao mesmo tempo, esclarecer o que é residual nessas práticas. Em outras palavras, esclarecer aquilo que, nessas práticas, escapa à análise sociológica ou econômica e enriquece por sua vez nosso conhecimento teórico das engrenagens da subjetividade que tais práticas podem fazer aparecer.

Esses resíduos, segundo Plon (1999), seriam frequentemente participativos daquilo que Lacan designava pela expressão "ça cloche", em que ele procurava sublinhar que o inadequado, o falho e a falta são inerentes ao ser humano, que é aí que se manifesta a sexualidade na medida em que faz obstáculos a este "girar em círculos", que nossas sociedades policiadas não param de temer, que o círculo fique imóvel. Ele finaliza, enfatizando a pertinência de chamar esse campo desse momento para frente, ou de novo, com toda clareza, de psicanálise aplicada.

É muito interessante a maneira com que Plon percorre o terreno espinhoso da psicanálise aplicada. Vale destacar alguns aspectos que interessam a essa pesquisa. $O$ psicanalista francês segue um caminho semelhante ao desse trabalho, pelo menos em seu início, em que é possível demonstrar a importância da psicanálise no conjunto da teoria freudiana. Depois disso, o autor, então, coloca-se diante de Yosef Yerushalmi e Lacan, e explicita a crítica desses autores à psicanálise aplicada: a extensão ilícita da interpretação aplicada a um material discursivo que não provém diretamente do inconsciente, pois não resulta das associações livres e da extensão aleatória do raciocínio analógico.

Yerushalmi afirma que Freud teria sido o primeiro a abrir essa Caixa de Pandora que constituiria a psicanálise aplicada, e Lacan, por sua vez, destacou a confusão que reinaria nesse campo de análise. Qual seria então a esperança presente no fundo da urna ou o alicerce em meio à confusão? Para Plon, a psicanálise aplicada seria o vetor da transmissão daquilo que escapa tanto à didática quanto ao tratamento propriamente dito. Retiradas as impurezas e a confusão, seria isso que restaria.

Haveria sim em Freud a presença de interpretações selvagens, mas isso não modificaria a dimensão teórica de seu trabalho, que não se limitou à ocorrência de uma simples aplicação. Plon (1999) também revela que as críticas sofridas pela psicanálise aplicada poderiam ser dirigidas ao pensamento dualista de Freud 
presente em sua obra como um todo, visto que ele evidenciaria a fragilidade epistemológica da psicanálise, revelada e rechaçada mais intensamente em algumas produções da psicanálise aplicada. Assim, tanto o termo psicanálise aplicada quanto o campo de pesquisa designado por ela ficariam reduzidos à caricatura em cima desses dois pontos fracos, porque seriam mais facilmente encontráveis aí que no terreno da "psicanálise pura" ou da "psicanálise científica".

Fiquemos com esses apontamentos em suspenso; por ora, eles já revelam importantes reflexões e hipóteses a partir das críticas feitas à psicanálise aplicada, 0 que contribui para o nosso intento de mapear o que elas podem esclarecer. Vejamos outras formulações.

Voltolini (2008), outro autor que se lança no debate acerca da psicanálise em sua interface com outras áreas do saber, depois de mencionar a relação da psicanálise com a Universidade, afirma que uma questão bastante ilustrativa disto que se poderia reconhecer como um "engajamento" da psicanálise na pesquisa universitária seria a que gira em torno de um termo que, curiosamente, se consagrou tanto no meio analítico quanto no meio universitário: o termo "aplicação".

O autor coloca que a ideia de aplicação surge para a psicanálise com inúmeras ressalvas. Para ele, seria da experiência clínica que surgiriam essas ressalvas, pois aquilo de que se trata ali tem mais a ver com o que se deveria chamar de implicação, e não "aplicação". Tanto Freud como Lacan, segundo Voltolini (2008), teriam insistido muito nessa ideia de que, em termos de clínica, não se trata de "aplicar" um conhecimento teórico. Em outras palavras, não se trata de ter uma teoria com a qual se vai para escutar o paciente, aplicando essa teoria. Isso só geraria uma clínica da "constatação", cujo paradigma seria a clínica médica.

No entanto, não se pode deixar de lembrar que, de fato, os dois autores concordariam com o fato de que na terapêutica não se trata de aplicar a teoria, aspecto relacionado ao método, mas ambos utilizam o termo psicanálise aplicada para tratar desse fazer clínico. Freud, no texto $A$ análise leiga, deixa isso claro ao falar das duas faces da psicanálise (aplicações da psicologia científica), e Lacan, ao nomear de psicanálise aplicada o ramo clínico.

Voltolini (2008) aponta, em seguida, que quando se fala em psicanálise aplicada, por exemplo, daria para entender o que faz com que se recorra a esse 
termo. Teria a ver com o campo aberto por Freud da relação da psicanálise com outros saberes, tema decisivo para pertença de psicanalistas na universidade.

O autor indaga como a psicanálise se portaria diante desses outros saberes. Para Freud, essa teria sido uma questão crucial, a que ele respondeu indicando que deveria existir um posicionamento peculiar, não homogêneo. A psicanálise não poderia se prestar facilmente ao chamado debate "interdisciplinar", dado o seu posicionamento atópico. Em Lacan, isso apareceria de modo mais explícito a partir de todo o desenvolvimento que ele faz da questão da cientificidade da psicanálise. $A$ psicanálise funcionaria como um "mais-um" das ciências, com elas, mas ocupando uma posição diferenciada entre elas.

O problema da relação de aplicação seria justamente o que ela comporta, dada esta condição de "mais-um" da psicanálise, de risco de se colocar como teoria "mestra". Voltolini (2008) revela, então, uma observação interessante da autora Cifali, a de que estaria ali o retorno, assim como se fala do retorno do recalcado, na posição de Freud, daquilo que se recusou na análise por ser considerado "educativo". Neste uso, a psicanálise apareceria numa posição marcadamente educativa, na medida em que pretende ensinar o outro campo sobre coisas que não são específicas dele. Haveria sinais evidentes desse uso "aplicativo" da teoria, quando as hipóteses do trabalho psicanalítico, que sempre estão sujeitas ao confronto do trabalho clínico, se apresentassem como certezas quando a teoria fosse "aplicada".

Para o autor, uma vez que se assume a posição de maestria, a psicanálise perderia sua especificidade ética para tornar-se uma teoria entre outras, uma visão de mundo a partir da qual se põe a prescrever papéis ou conselhos. Voltolini (2008), então, questiona se as noções de pesquisa e aplicação não seriam antinômicas: se, quando estamos aplicando, não poderíamos estar pesquisando. Assim, o termo "pesquisa aplicada" parece-lhe paradoxal.

Jerusalinky (2008), nessa direção, afirma que a aplicação deriva de um conhecimento já feito, e que então ele vai moldar, destrinchar, ordenar, classificar o fenômeno de acordo com esse conhecimento. Isso quer dizer que a extensão da pesquisa que uma aplicação proporciona é muito curta; ela iria muito mais para fora da teoria, que para replicar no interior da teoria e levá-la a se interrogar. Seria como se, fazendo uma aplicação, déssemos por certo determinadas conclusões, e elas 
passassem a servir para ordenar o mundo.

De fato, afirma Jerusalinsky (Ibidem), Freud apreciaria esse exercício da aplicação por dois motivos. Em primeiro lugar, porque ele tinha a pretensão, através desse trânsito pela ordem do saber, de produzir conhecimentos, e então poder aplicá-los. O segundo motivo parece ao autor ser, em Freud, a simpatia com que ele enxergava esse exercício; ele precisava de provas da consistência de sua teoria, e demonstrar sua aplicabilidade aos fenômenos dos mais diversos trazia-Ihe o benefício de uma comprovação que poderia exibir para os cientistas.

A seguir traremos dois autores com ideias afins. Herrmann (2005) introduz o termo clínica extensa em oposição à psicanálise aplicada. Frayze-Pereira (2008) aproxima-se teoricamente do primeiro, e é reconhecido por seus trabalhos na interface entre Psicanálise e Arte.

Herrmann (2005), nesta produção específica, fala de sua preocupação com a Psicanálise. Aponta que, uma vez estabelecidas, ciências podem durar tanto quanto a cultura que as engendrou, mas doutrinas definham, ofícios caducam e uma técnica terapêutica não seria nem bom pensar.

Em seguida, o psicanalista propõe ao leitor imaginar como seria analisar sem burocracia, arriscando umas ideias sobre a psique, sem medo de ofender a escola alheia, para depois indicar que se trata de pura tentação: afinal, com quem dividiria as dúvidas? Justamente porque ele não deseja, no íntimo, o desaparecimento da investigação psicanalítica, da análise do consultório e de nós mesmos, ele diz dever reconhecer, não obstante, uma circunstância de risco cuja resposta ele indica qual seria: A Clínica Extensa.

Ora, mas o que o autor quer dizer com o termo Clínica Extensa? Herrmann (2005), no mesmo texto, aponta que não se trata de uma novidade, seria somente a vasta medida em que o método ultrapassa a técnica. O método psicanalítico usado fora do consultório, por exemplo, onde a técnica padrão é inexequível. Ou, no consultório, sendo quase tudo o que se faz, mas raramente se conta. Ele destaca que a técnica - livre associação, atenção flutuante, interpretação transferencial, neutralidade, etc. - seria em geral uma boa coisa, dependendo de como cada qual a traz em procedimento concreto: de modo aberto, como inspiração, ou de modo fechado, como um ritual. 
O autor salienta que o método psicanalítico criado por Freud que, nas palavras da Teoria dos Campos, consiste em ruptura de campo, vórtice, expectativa de trânsito, etc., seria sempre clínico. Isso é verdadeiro; porém, este trabalho possuiria um espectro de utilização incomparavelmente maior que a técnica. Sobretudo, enfatiza o autor, se, por técnica, entende-se técnica padrão, dentro de uma moldura padrão, com uma teoria padrão. Hermann indica que, se acorrentarmos o método ao padrão, e correm os boatos do fim do padrão, sobreviria um desespero que levaria parte dos analistas a se agarrar ao padrão, enquanto outra parte gostaria de praticar qualquer coisa e em qualquer lugar, sem reflexão, dando-lhe o nome de psicanálise. Ora, afirma o psicanalista, quando há risco, nada melhor que refletir. É isso que ele irá fazer nesse texto.

Em Freud, aponta Herrmann (2005), a Psicanálise ocupava uma área muito maior que a terapia de consultório; posteriormente, dentro do movimento psicanalítico, não se expandiu, encolheu. As grandes análises freudianas da cultura, da literatura e dos mitos deram lugar a uma prática clínica muito estreita. As mesmas interpretações, variando apenas segundo a ênfase de cada grupo psicanalítico, vão e voltam no cenário de um setting ritualístico. Os esquemas interpretativos que traduzem automaticamente o que diz um paciente, como alusão ao analista, como repetição de situações da infância remota, como jogos de palavras, estariam perdendo seu encanto e sua eficácia.

A ousadia teórica de Freud tampouco teria encontrado muitos seguidores à altura, indica Herrmann (2005). Restariam comentários de suma erudição e perspicácia sobre a obra freudiana, assim como trabalhos clínicos valiosos. No entanto, seria difícil naquele momento imaginar uma proposta teórica que entusiasmasse os analistas, que abalasse as ciências, que motivasse a cultura. Por seu lado, afirma o autor, a teoria psicanalítica teria se adaptado à prática terapêutica, reduzindo-se à psicologia individual, e também aos grupos de formação, fragmentando-se em sistemas doutrinários escolásticos. Os mesmos acordos políticos que determinaram os centros de poder psicanalítico convencionaram a extensão permissível da clínica, a moldura (ou setting) e, consequentemente, o nível de sua teorização, definindo assim a clínica padrão e a técnica padrão.

Para Herrmann (2005), a clínica psicanalítica viria sucumbindo ao padrão das sessões, das interpretações, da atitude convencional. Na travessia atual, a clínica 
deveria estender-se, mas antes seria forçoso, para Herrmann, que se elevasse o pensamento. Alta teoria e clínica extensa seriam inseparáveis. A primeira garantiria a elevação teórica que ilumina uma área mais ampla, como quando se levanta uma tocha. Seria a generalização dos conceitos psicanalíticos, em especial o de inconsciente, às múltiplas condições do homem no mundo, não só na psicanálise de consultório. Seu pilar central seria a interação entre teoria psicanalítica e epistemologia.

Em seguida, o psicanalista aponta sugestões de clínica extensa. A primeira ideia que desperta a expressão clínica extensa seria a de aplicação do método psicanalítico a situações exteriores ao consultório, tais como o hospital, a clínica universitária, a consulta médica, a escola e, de modo geral, a prática junto à população desprovida de recursos. Em si, não haveria nada de errado nesse entendimento usual, ele mereceria apenas uma precisão. Por clínica extensa, ele não pretende referir-se tão somente à extensão a outros domínios, como também à recuperação daquilo que constitui o nosso patrimônio original, em parte abandonado com o tempo. Como a atenção analítica seria sempre clínica, a psicanálise da cultura e da sociedade, correlação de mão dupla com a literatura e as artes, a própria integração com o reino das ciências, tudo isso seria clínica extensa.

Herrmann (2005) acrescenta ainda que para se ter uma noção mais clara da amplitude dessa ideia, mesmo a prática de consultório poderia figurar como clínica extensa. Não seriam os pacientes de análise que escasseariam, somente os da clínica padrão. Em síntese, a seu ver, o risco da circunstância atual consistiria na identificação do método psicanalítico com a clínica padrão, deixando que aquele se extinga com a crise desta, e assim furtando à Psicanálise o precioso tempo histórico para se fundar como ciência da psique.

Frayze-Pereira (2008), por sua vez, muito alinhado às teorizações de Herrmann, aponta que, em Freud, com efeito, a psicanálise ocupava uma área muito maior do que a prática de consultório. Nele, encontraríamos grandes análises da cultura, da literatura, da religião e dos mitos com o uso do método psicanalítico. No entanto, depois dele, destaca o autor, a tendência teria sido o padrão psicanalítico invadir inclusive esse campo, produzindo uma prática normalizada, pautada na imagem da clínica tradicional de consultório: as mesmas interpretações acabam sendo produzidas no cenário imaginário de um setting ritualístico. 
Frayze-Pereira (2008), então, trata da relação da psicanálise com a arte. Segundo ele, quando se pensa nela, imediatamente viria à mente o texto sobre Leonardo da Vinci (FREUD, 1910), que teria estimulado a criação da chamada "psicanálise aplicada à arte" e ensejado uma série de estudos sobre as chamadas "personalidades artísticas". Entretanto, destaca Frayze-Pereira (2008), esse estudo corresponderia a uma "má psicanálise da arte", uma psicanálise equivocadamente biográfica. $\mathrm{E}$, sobre vários aspectos, o texto sobre Leonardo seria discutível.

Sem entrar em detalhes na discussão desse texto, o autor destaca que interessa considerar o que significaria exatamente a expressão: "psicanálise aplicada". Como o nome diz, "psicanálise aplicada" significaria a aplicação da teoria e da técnica psicanalíticas a tudo o que não seria fenômeno surgido na sessão de análise, isto é, os fenômenos sociais e políticos. Daí ter surgido, afirma FrayzePereira (2008), desde Freud, o imenso campo de estudos de psicanálise e arte, psicanálise e literatura, psicanálise e religião, psicanálise e política, psicanálise e comunicação de massa e assim por diante.

Entretanto, haveria que se reconhecer, segundo Frayze-Pereira (2008), que a "psicanálise aplicada" procuraria se concentrar sobre uma dimensão do objeto que não seria abordada por outras disciplinas: a dimensão inconsciente. E que ela buscaria evidenciar as características do psiquismo contidas nas obras da cultura. Nesse sentido, a proposta dessa psicanálise seria defensável. O autor indaga qual seria a mais séria razão das críticas.

Segundo ele, elas decorreriam do fato de quase sempre os estudos de "psicanálise aplicada" associarem-se a outro modo de fazer psicanálise, sobretudo por aqueles que a conhecem apenas através dos livros, denominado criticamente por Freud "psicanálise silvestre" (1910). Para delinear o que chama de arte como extensão da clínica ou campo artísticos como clínica extensa, Frayze-Pereira (2008) aponta um aspecto importante da crítica contemporânea da arte, a saber, a abertura a outras perspectivas com origens diversas - na filosofia, nas ciências humanas e até nas ciências naturais.

O autor, então, pondera que se a crítica seria específica na sua abertura às outras disciplinas, estas possuem especificidades que, no jogo interdisciplinar, devem ser respeitadas para não serem desfiguradas. 
Mais adiante ele, então, indica que a psicanálise realmente interessada na arte e compatível com ela não poderia ser "aplicada", mas implicada. FrayzePereira (2008) salienta que esse é um termo que passou a usar nos seus estudos e que significa a psicanálise derivada das artes ou engastada nelas, pois não é uma forma conceitual preestabelecida a se aplicar à matéria exterior, não é um modelo que ajusta abstratamente o objeto artístico às suas exigências teórico-conceituais.

Por fim e não menos importante, mostra-se essencial refletir sobre as contribuições de Pontalis (2005) nesse debate. Pudemos dar indícios dessa reflexão ainda na Introdução, e neste momento, iremos aprofundá-la. Ele inicia seu artigo indicando a questão central que seu texto buscará abordar, apontando que a primeira tentação é atribuir, de fora, limites para o analisável, e isso se daria em dois registros aparentemente muito distantes um do outro:

o da extensão do método e da interpretação psicanalíticos para além das fronteiras definidas pelo âmbito do tratamento (a chamada psicanálise "aplicada"), o do alcance da técnica psicanalítica conforme as organizações psicopatológicas em questão (problema das "indicações" e "contraindicações"). (PONTALIS, 2005, p.211)

Segundo o autor, na verdade, esses dois problemas, sobre os quais muito se debateu nos últimos anos sem que se chegasse, no seu entender, a uma formulação rigorosa, seriam menos heterogêneos do que pareceriam num primeiro olhar. Ambos concerniriam ao uso legítimo do instrumento psicanalítico.

E, para exemplificar esse argumento, ele afirma que (Ibidem, p.211):

Quando nos perguntamos, por exemplo, em que condições um psicanalista pode se autorizar a tratar de fatos sociais e estéticos questão que não concerne apenas aos psicanalistas -, estaremos tão longe quanto imaginamos da preocupação de determinar, de acordo com critérios precisos, que casos estariam ou não sujeitos a um tratamento psicanalítico - questão esta que é exclusivamente da competência dos psicanalistas?

Para Pontalis (2005), em ambas as circunstâncias se trataria efetivamente de fixar limites para o campo psicanalítico, de decidir o que, por natureza, foge dele.

No decorrer do texto, no entanto, o autor faz breves menções ao primeiro dos registros, como o da extensão do método e da interpretação psicanalíticos para além 
das fronteiras definidas pelo âmbito do tratamento (a chamada psicanálise "aplicada"). Ele privilegia as discussões que envolvem o segundo deles: o do alcance da técnica psicanalítica conforme as organizações psicopatológicas em questão. Mesmo com essa predominância, é possível identificar alguns argumentos que podem auxiliar na reflexão sobre a psicanálise "aplicada".

Logo no início do artigo, Pontalis (2005) discorre acerca do segundo problema - o das indicações - e aponta que seríamos obrigados a reconhecer uma extrema variedade de opiniões entre os analistas mais experientes. Seria muito provável, diz ele, que, se somássemos as respostas divergentes, chegássemos ao resultado paradoxal e contraditório de que todas as organizações psicopatológicas podem ser abordadas pela psicanálise; nenhuma, nem as neuroses mais "clássicas", seriam realmente acessíveis em suas raízes. Ele, então, indaga o que deveria ser concluído desse fato, já que nada pode ser objetivado, uma vez que o progresso da análise depende essencialmente do que possa surgir no espaço analítico criado pelas duas partes em questão. Em suma, o que ele quer enfatizar é que, dessa maneira, o analisável não conheceria outros limites além daqueles do analista.

O psicanalista francês reconhece a afirmação, mas aponta que isso rapidamente levaria a caucionar um subjetivismo sem limites, do qual não se poderia esperar outra coisa além da celebração das virtudes da "relação" ou de uma constatação do funcionamento combinado da transferência e da contratransferência (PONTALIS, 2005). Ele indica, então, que sem ignorar essa dimensão relacional ou esta comunicação de inconsciente para inconsciente, seria possível almejar um passo a mais.

E joga luz num aspecto essencial quando destaca, "de passagem", que se os analistas fossem consequentes com a ideia de que toda a eficácia da análise depende de uma relação que não poderia ser dita sem se travestir ao ponto de fazer desaparecer o que ela comporta de verdade, eles fariam voto de silêncio. Mas assiste-se, afirma Pontalis (2005), ao fenômeno inverso: cada um, à sua maneira, tenta transmitir o que é para ele a análise, esquecendo até o "para ele". Ele, então, conclui que o dogma se esconderia na clínica "subjetiva" tanto quanto a fantasia deixa-se entrever no discurso que se quer "científico".

O autor, em seguida, apresenta o que seria "o passo a mais". Ele aborda a questão por outro lado, menos dependente das singularidades individuais. Segundo ele: 
a história da psicanálise consistiu menos em definir os limites de sua ação para precisá-los cada vez melhor, como um Estado que procedesse a incessantes retificações de fronteiras, do que em ficar perto desses limites, como um povo nômade que nunca se instalasse numa província, mesmo que ela fosse distante e afastada das civilizações reinantes, e só encontrasse seu espaço nos confins, seu motivo de existir nessa vizinhança sem nome com uma linha que ele mesmo, independentemente de qualquer mapa está traçando. (PONTALIS, 2005, p.213)

Em nota de rodapé, o psicanalista ainda pondera que, evidentemente, essa seria uma concepção ideal. Não seria difícil mostrar, afirma ele, que a psicanálise, em sua realidade, sobretudo institucional, sempre funcionou mais conforme 0 modelo do Estado.

Pontalis (2005), então, lembra o leitor de que o modo como a psicanálise se constituiu pode induzir a erro. Com efeito, o esforço de Freud teria necessariamente se sustentado por uma exigência de delimitação que poderia ser encontrada em vários níveis e, portanto, afirma o autor, só pode se ampliar:

No conglomerado do que o termo neurose ou "doença nervosa" designava na época, era preciso primeiro diferenciar as psiconeuroses das neuroses atuais; depois, uma vez circunscrito o campo da psiconeurose, distinguir nela os diversos tipos de organização - neuroses obsessivas, histéricas, fóbicas --, menos pela identificação de sintomas visíveis do que pela descoberta dos mecanismos psíquicos em ação; o modo de funcionamento neurótico passa então a ser situado em relação à perversão e à psicose. (2005, p.213)

Neste ponto, o psicanalista francês enfatiza que essa exigência nosográfica de definição de quadros clínicos estaria estritamente correlacionada tanto com a construção teórica, como com a instauração da situação analítica. Tanto numa como na outra, poder-se-ia reconhecer, mais afirmada ainda, a preocupação de definir limites. Tudo estaria aí: nosografia, teoria, técnica, mas não haveria nada de redutor, não se trataria de fazer fenômenos entrarem à força na estreiteza de um quadro, mas, inversamente, de criar o (en)quadro para que o objeto psicanalítico se constitua. Pontalis aponta, então, que já que está falando de quadro, poderia falar de 
revolução psicanalítica, isso no sentido de uma revolução pictural.

Ora, pode-se perguntar o que ele queria dizer com isso. O autor indica, em seguida, que era preciso a um só tempo criar a "ficção" de um aparelho psíquico, inventar uma situação terapêutica na qual esse aparelho funcionaria numa colocação entre parênteses e forjar um aparelho conceitual que tivesse suficiente jogo em sua organização interna, bem como ferramentas suficientemente precisas, para entender a complexidade desse funcionamento. Modo de pensar que Pontalis reconhece como circular, em que o caráter "arbitrário" do protocolo da análise, por exemplo, se vê justificado na medida em que permitiria observar, nas condições as mais puras possíveis, as estruturas e as operações do aparelho psíquico, ele mesmo elaborado a partir da situação criada. Essa seria uma crítica epistemológica feita à Psicanálise.

Ele, então, afirma que, na verdade, seria por não haver coincidência entre prática e teoria, mas sim distância, que não se procuraria preencher, que se poderia falar legitimamente de um movimento analítico. E, nesse momento, parece ficar nítido o passo a mais que almejava Pontalis (2005) ao trazer alguns aspectos históricos da psicanálise: a ênfase no aspecto móvel e aberto que a Psicanálise assume.

Isso teria começado cedo: Pontalis (2005) destaca que, passado o período em que os primeiros discípulos podiam renovar o encantamento de verificar e ilustrar por meio de um material ainda fresco as descobertas do fundador, a clínica e o pensamento psicanalíticos - eles são inseparáveis - sempre puseram em dificuldades os primeiros modelos freudianos.

Para enfatizar o que disse antes, ele ainda afirma que, nos últimos cinquenta anos, qualquer assembleia psicanalítica estaria autorizada a tomar como tema aquele que um recente congresso internacional escolheu: avaliar as mudanças na prática e experiência analíticas, avaliar suas implicações ao mesmo tempo teóricas, técnicas e sociais.

Também Freud, afirma Pontalis (2005), em sua própria evolução, sempre viu no obstáculo o motivo desencadeante, a moção pulsional, de um progresso teórico. O autor vienense submeteria sua própria ciência ao princípio que a fez nascer: nunca recusar o irracional, o incoerente, o inquietante por exclusão em termos 
negativos, mas pensar aquilo que não conseguimos pensar, aquilo que se apresenta para cada um como tendo ultrapassado o limiar do tolerável.

E é nesse contexto da discussão que o psicanalista francês faz considerações sobre o primeiro dos registros, apresentado no início de seu artigo (PONTALIS, 2005, p.215):

\begin{abstract}
Mesmo o que é erroneamente entendido como excursões - de Totem e Tabu ao Mal-estar na civilização - demonstra, mais que uma vontade de anexação, o propósito de ir ali onde algo resiste, como se só pudesse haver psicanálise ali, onde há o encontro, o teste, dos limites do analisável.
\end{abstract}

Ele acrescenta ainda que ali onde esse teste é evitado, particularmente, na "análise" dos textos, mesmo que se conjugue o espírito de geometria com o espírito de finura, a psicanálise, por mais maciçamente presente que pareça estar pelo uso dos conceitos ou do método, simplesmente não aparece. Assim, seria necessariamente a prática - porque fazer psicanálise não é essencialmente uma "leitura" - que iria atualizar a questão dos limites e lhe dar figuras concretas.

E, nesse sentido, os exemplos seriam inúmeros, afirma Pontalis (2005); não haveria um continuador de Freud que não tenha passado por essa experiência, contado com ela e pagado por isso; entretanto, nem todos encontrariam aí a mola propulsora de seu pensamento.

Desse modo, chega-se ao ponto final, depois do extenso percurso por diferentes autores e obras que se debruçaram sobre a tensão que envolve a psicanálise aplicada. Ela é representada ao longo dos textos pelas abominações da Caixa de Pandora e pela confusão, como vimos com Plon (1998) quando ele se refere, respectivamente, às críticas de Yosef Yerushalmi e Jacques Lacan, e pela análise selvagem, como pontuam vários dos autores. Ela parece ser, assim, uma heresia ao todo da psicanálise. No entanto, ao se aprofundar no debate, também é possível notar que a princípio não se trata de rechaçar as incursões psicanalíticas em direção a outros campos, mas de expulsar um tipo de fazer que se mostra 
reducionista e impreciso. Isso nos mostram Plon (1999), Voltolini (2008), Jerusalinsky (2008), Herrmann (2005) e Frayze-Pereira (2008).

Plon (1999) e Pontalis (2005) reconhecem a fragilidade epistemológica da psicanálise e consideram exatamente essa a sua especificidade. Como se pode notar são inúmeras as tentativas de apontar saídas: Lacan (1998), Voltolini (2008), Herrmann (2005) e Frayze-Pereira (2008); no geral, esses autores mencionam outras denominações que, livres do fantasma da psicanálise aplicada, podem garantir a legitimidade e a validade desse fazer: psicanálise em extensão, psicanálise implicada ou a clínica extensa.

Esses aspectos trazidos até aqui são meras constatações, por assim dizer, factuais e concretas. Qual seria o conflito em jogo?

A impressão é de que é perigoso adentrar nesse diálogo com outros saberes; perdem-se as garantias do fazer psicanalítico; corre-se esse risco. $\mathrm{Na}$ interface com outras áreas, mais do que talvez no consultório, isso fique manifesto. Fora do particular das paredes do consultório, o ambiente é inóspito e espinhoso, para usar uma expressão de Freud. E está em questão a própria transmissão da psicanálise, um ramo importante dela.

Ao longo do primeiro capítulo deste trabalho, pode-se observar que Freud não escondia que suas incursões eram decisivas para a pertença da psicanálise em relação às outras ciências, preocupando-se em dar à Psicanálise o estatuto de ciência. Os efeitos produzidos por essas produções estariam estreitamente relacionados com o alcance desse objetivo, fosse para validar algumas de suas hipóteses, fosse para levar a psicanálise para outras terras, disseminá-la e expandila. Ele queria ser um grande pensador e não se pode negar que Freud tinha amplas ambições.

Algumas tentativas foram rápidas e por ora até didáticas na medida em que ilustravam muito bem certos pontos da teoria freudiana. No entanto, não se pode esquecer que outras foram muito além disso. De fato, não só levaram reflexões 
importantes para as outras disciplinas, como serviram de pilares importantes para a teoria psicanalítica.

E isso tem seus efeitos seja na clínica, seja fora dela. Como destaca Pontalis (2005), entre a teoria e a prática existe um intervalo, e seria nele que se daria o movimento psicanalítico. Na presença do risco, certa vertente agarra-se ao padrão, a tentativa é de dar limites claros; outra busca caminhar nas fronteiras do analisável. Lá mesmo onde ocorre o teste dos limites, nos confins. 


\section{Considerações Finais}

Diante do percurso feito neste trabalho, o que é possível recolher no que se refere à questão nominal, aos chamados e lembretes feitos aos psicanalistas, assim como aos limites para o analisável? $O$ que se mostrou em jogo com o fazer psicanalítico voltado para outros campos?

Com Freud, identificamos as raízes da ida da psicanálise até outros campos. $\mathrm{O}$ trajeto se coloca como fundante, na medida em que nasce juntamente com a Psicanálise. Assim, não é possível separar a face clínica da sua face aplicada para outros campos do saber. Dessa forma, falar dos textos sociais freudianos mostrase impreciso na medida em que esses textos, assim como aqueles voltados à estética, guardam relação direta com a metapsicologia e com a terapêutica.

Freud ia como um diletante em direção a outros campos, ora tomado por hesitações diante das hipóteses feitas, ora impactado pelo desejo de expansão da psicanálise. Isso sem nunca esconder a importância desse fazer psicanalítico e sua imbricação com sua teoria. Freud contou com auxiliares hábeis no começo desse desejo de abertura, mas sabia da necessidade de contar com profissionais de outras áreas do conhecimento.

É verdade que nos primórdios da psicanálise, sua institucionalização com a IPA revelou a necessidade de se colocar limites, de cercear a Psicanálise para que ela não se desconfigurasse. $E$, agarrados à técnica e aos limites, muitos psicanalistas cuidaram de empobrecê-la, na medida em que cercearam a invenção que ressignifica a Psicanálise. No entanto, foram muitas as produções freudianas e de seus contemporâneos em direção à interface com outros campos do saber, que produziram inflexões importantes seja à Psicanálise seja às outras áreas do conhecimento.

Lacan, por sua vez, rompeu com certa lógica de "fazer psicanálise" e passou a sofrer retaliações por isso. A Instituição Psicanalítica colocou para ele questões insolúveis, como a impossibilidade de funcionar assim mesmo como os princípios inconscientes. No entanto, mesmo diante das dificuldades, ele não evitou esse 
debate, colocou-se dentro das discussões e, mais do que isso, propôs um corte importante no movimento psicanalítico com a criação da Escola Francesa de Psicanálise. Além disso, o psicanalista francês propôs um avanço importante ao trazer os conceitos de "psicanálise em intensão" e "psicanálise em extensão", tendo a transmissão da psicanálise como ponto central.

Em relação à busca de sentidos no debate atual, vale considerar a pulverização da Psicanálise em suas várias instituições, seja nas universidades e, também, na própria cultura. Pensadores do mais alto calibre do pensamento contemporâneo, e muitos psicanalistas e não psicanalistas, tomam a Psicanálise como referência no debate entre áreas do conhecimento. Pudemos mostrar, também, em que medida os vários nomes dados ao fazer psicanalítico voltado a outros campos relacionam-se com a tentativa de afastar-se da mera aplicação dos conceitos e buscam salvaguardar a psicanálise de equívocos, isso no intuito de continuar levando-a a outras áreas.

De maneira geral, a psicanálise aplicada parece colocar em jogo a fragilidade epistemológica da Psicanálise, revelando-se como o elo mais fraco se comparada à clínica. Nela recai mais facilmente o perigo educativo, a saber, a psicanálise colocarse como teoria mestra ou visão de mundo, perdendo sua característica principal, ou seja, reconhecer as falhas, os lapsos, as contradições, como efeitos do inconsciente.

O que parece estar em pauta tendo como sintoma os vários nomes ou os chamados e lembretes é a transmissão da psicanálise, essa é a esperança que jaz no fundo da Caixa de Pandora. A sensação é de que algo precisa ser protegido, e nesse sentido muitas são as posições defensivas, que muitas vezes impõem limites para o analisável e enrijecem a formação. Um recuo, que pode impedir que a psicanálise coloque-se a pensar na abertura com outros campos, e que contribua com seu olhar estrangeiro.

Vale destacar, por fim, que não nos propusemos a indicar qual seria a denominação mais adequada quanto ao fazer psicanalítico voltado a outros campos, mas apenas a delinear as questões em torno do termo psicanálise aplicada.

Ainda restam muitas perguntas sem respostas, e ao longo desse trabalho pretendeu-se buscar pistas para o que fica em torno da psicanálise aplicada. Porém, não se pode esgotar essa discussão. 
Um trajeto possível e vislumbrado que, infelizmente, não pôde ser desenvolvido, foi percorrer alguns dos textos freudianos, centrais no que se refere à relação com outros campos, que poderiam evidenciar em que medida foi ou não possível produzir inflexões, seja na Psicanálise, seja em outra área do saber. Outro recorte interessante teria sido inventariar autores da atualidade que se propõem a avançar nesse debate ao colocarem a Psicanálise em interface com outros saberes. 


\section{Referências bibliográficas}

BIRMAN, J. Psicanálise, Ciência e Cultura. Rio de Janeiro: Jorge Zahar, 1994.

COSTARDI, G. G. Para além da psicanálise pura.... In: J. Guilhermo Milán-Ramos e Nina Virgínia de Araújo Leite. (Org.). EntreAto - o poético e o analítico. 1ed. Mercado de Letras: Campinas, 2011, v. 1, p. 203-210.

DE CERTEAU, M. (1975). A escrita da história. Rio de Janeiro: Forense, 2011. . (1987). História e Psicanálise: entre ciência e ficção. Belo Horizonte: Autêntica Editora, 2011.

ENDO, Paulo César. O psicanalista é um intelectual? In: Pulsional rev. psicanál., São Paulo, v. 21, n. 3, set. 2008 . Disponível em <http://pepsic.bvsalud.org/scielo.php?script=sci_arttext\&pid=S1517 53162008000300003\&lng=pt\&nrm=iso >. Acessos em 10 jan. 2012.

ENRIQUEZ, E. Psicanálise e ciências sociais. In: Ágora: estudos em teoria psicanalítica, Rio de Janeiro, v.3, n.2, p. 153-174, jul./dez. 2005.

ESMAN, A. H. What is 'applied' in 'applied' psychoanalysis? In: Int. J. Psycho-Anal., London, v. 79, p. 741- 752, 1998. 
FRAYZE-PEREIRA, J. A. Freud e Herrmann: psicanálise aplicada e clínica extensa. In: MONZANI, J.; MONZANI, L. R. (orgs.). Olhar: Fábio Herrmann. São Paulo: Pedro e João Editores/ CECH - UFSCar, 2008.

FUKS, B. B. Freud e a cultura. Rio de Janeiro: Jorge Zahar, 2003.

FREUD, S. (1907). Prospecto para Schriften Zur Angewandten Seelenkunde. In:__. Edição Standard brasileira das obras psicológicas completas de Sigmund Freud. Rio de Janeiro: Imago, 1996. (v.9, p.227).

. (1910). Leonardo da Vinci e uma lembrança da sua infância. In:

Edição Standard brasileira das obras psicológicas completas de Sigmund Freud. Rio de Janeiro: Imago, 1996. (v.11, p.67-141).

. (1910). Psicanálise 'Silvestre'. In: Edição Standard brasileira das obras psicológicas completas de Sigmund Freud. Rio de Janeiro: Imago, 1996. (v.11, p.229-339)

. (1913). Totem e Tabu. In: Edição Standard brasileira das obras psicológicas completas de Sigmund Freud. Rio de Janeiro: Imago, 1996. (v.13, p.13162).

. (1914). A história do movimento psicanalítico. In: Edição Standard brasileira das obras psicológicas completas de Sigmund Freud. Rio de Janeiro: Imago, 1996. (v.14, p.13-73).

. (1916). Conferência X: Simbolismo nos sonhos. In: Edição Standard brasileira das obras psicológicas completas de Sigmund Freud. Rio de Janeiro: Imago, 1996. (v.15, p.151-170).

. (1919). Sobre o Ensino da Psicanálise nas Universidades. In:

Edição Standard brasileira das obras psicológicas completas de Sigmund Freud. Rio de Janeiro: Imago, 1996. (v.17, p.183-189).

. (1921). Psicologia de grupo e Análise do Ego. In: Edição Standard brasileira das obras psicológicas completas de Sigmund Freud. Rio de Janeiro: Imago, 1996. (v.18, p.79-154). 
(1923). Dois verbetes de Enciclopédia. In:

Edição Standard

brasileira das obras psicológicas completas de Sigmund Freud. Rio de Janeiro: Imago, 1996. (v.18, p.249-274).

. (1924). Uma breve descrição da Psicanálise. In: Edição Standard brasileira das obras psicológicas completas de Sigmund Freud. Rio de Janeiro: Imago, 1996. (v.19, p.211-234).

- (1926). Análise Leiga. In: - Edição Standard brasileira das obras psicológicas completas de Sigmund Freud. Rio de Janeiro: Imago, 1996. (v.20, p.173-248).

. (1930). O mal-estar na civilização. In: - Edição Standard brasileira das obras psicológicas completas de Sigmund Freud. Rio de Janeiro: Imago, 1996. (v.11, p.65-148).

- (1933a). Conferência XXXIV: Explicações, Aplicações e Orientações. In:___ Edição Standard brasileira das obras psicológicas completas de Sigmund Freud. Rio de Janeiro: Imago, 1996. (v. 22, p.135-154).

- (1933b). Novas conferências introdutórias sobre a psicanálise. In:

O mal-estar na civilização, novas conferências introdutórias à psicanálise e outros textos (1930-1936). São Paulo: Companhia das Letras, 2010. (v. 18, p.123-354).

- (1933c). Prefácio a A vida e as obras de Edgar Allan Poe: uma interpretação psicanalítica de Marie Bonaparte. In: Edição Standard brasileira das obras psicológicas completas de Sigmund Freud. Rio de Janeiro: Imago, 1996. (v. 12, p.252).

. (1939). Moisés e o Monoteísmo: três ensaios. In: Edição Standard brasileira das obras psicológicas completas de Sigmund Freud. Rio de Janeiro: Imago, 1996. (v.23, p.15-152).

. Sigmund Freud \& Sándor Ferenczi: correspondência. Vol. 1. Tomo 2. Rio de Janeiro: Imago, 1995.

FUKS, M. P. Mesa de abertura. In: Estados Gerais da Psicanálise: Segundo Encontro Mundial, 2003, Rio de Janeiro. Disponível em: http://www.estadosgerais.org/mundial_rj/port/cb_m_fuks.htm. Acesso em: 18 de out. 2010.

A psicanálise latino-americana diante dos fenômenos sócio-políticos (sic) e 
o mal-estar na cultura. In: IV Encontro Latino Americano dos Estados Gerais da Psicanálise, 2005, São Paulo. Disponível em: http://www.estadosgerais.org/encontro/IV/PT/trabalhos/Mario_Pablo_Fuks.php. Acesso em: 18 de out. 2010.

FRAYZE-PEREIRA, J. A. Freud e Herrmann: Psicanálise aplicada e clínica extensa. In: MONZANI, J; MONZANI, L. R. (orgs.). Olhar: Fábio Herrmann: uma viagem psicanalítica. São Paulo: Pedro e João Editores, 2008.

GAY, P. Freud: uma vida para nosso tempo. São Paulo: Companhia das Letras, 1989.

HERRMANN, F. Clínica extensa. In: BARONE, L. M. C. (Coord.). A psicanálise e a clínica extensa. São Paulo: Casa do Psicólogo, 2005.

KATZ, C. S.; MELMAN, C.; KOLTAI, C.; FUKS, M. P. Psicanálise e cultura: uma herança freudiana? [Debate]. Revista Percurso, n.34, 2005.

KOLTAI, C. Política e Psicanálise: O estrangeiro. São Paulo: Escuta, 2000.

KUPERMANN, D. Transferências cruzadas: uma história da psicanálise e suas instituições. Rio de Janeiro: Revan, 1996.

JONES, E. A vida e a obra de Sigmund Freud. Vol.3. Rio de Janeiro: Imago, 1989. 
LACAN, J. Escritos. Rio de Janeiro: Jorge Zahar, 1998.

. Outros escritos. Rio de Janeiro: Jorge Zahar, 2003.

MAJOR, R. Não há democracia sem a psicanálise. In: Estados Gerais da Psicanálise: Segundo Encontro Mundial, 2003, Rio de Janeiro. Disponível em: http://www.estadosgerais.org/mundial_rj/port/cb_m_RMajor.htm. Acesso em: $18 \mathrm{de}$ out. 2010.

.Convocação dos Estados Gerais da Psicanálise. Disponível em: http://www.estadosgerais.org/historia/convocacao-portugues.shtml. Acesso em: 18 de out. 2010

- O inconsciente sociopolítico. Ágora: estudos em teoria psicanalítica. Rio de Janeiro, jan./jun. 2006. Entrevista concedida a Leneide Duarte-Plon.

MCGUIRE, W. A correspondência completa de Sigmund Freud e Carl G. Jung. Imago: Rio de Janeiro, 1993.

NUNBERG, H; FEDERN, E. Actas de la Sociedad Psicoanalítica de Viena. Tomo I. Buenos Aires: Ediciones Nueva Visión, 1979.

PLON, M. A face oculta da análise leiga. Ágora: estudos em teoria psicanalítica. Rio de Janeiro, v.2, n.1, p. 91-108, jan./jun. 1999.

PONTALIS, J. B. Bordas e Confins. In: PONTALIS, J. B. Entre o sonho e a dor. Aparecida, SP: Idéias (sic) e Letras, 2005. p. 211-225. 
ROUANET, S. P. Psicanálise e Cultura. In: Estados Gerais da Psicanálise: Segundo Encontro Mundial, 2003, Rio de Janeiro. Disponível em: http://www.estadosgerais.org/mundial_rj/port/cb_c_rounet.htm. Acesso em: 18 de out. 2010.

ROUDINESCO, E. História da Psicanálise na França 2 (1925-1985). Rio de Janeiro: Jorge Zahar, 1988.

ROUDINESCO, E., \& PLON, M. Dicionário de Psicanálise. Rio de Janeiro: Jorge Zahar, 1998.

SOUZA, O. Reflexão sobre a extensão dos conceitos e da prática. In: ARAGÃO, L. T. de et al. Clínica do social: ensaios. São Paulo: Escuta, 1991.

VIANNA, H. B. Não conte a ninguém: contribuições à história das Sociedades Psicanalíticas do Rio de Janeiro. Rio de Janeiro: Imago, 1994. 